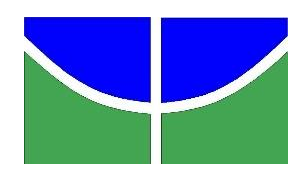

Universidade de Brasília

Centro de Excelência em Turismo

Mestrado Profissional em Turismo

\title{
Construção do Conhecimento do Turismo: competências necessárias para o exercício da profissão do Turismólogo
}

\author{
Tamara Silva Nicolau
}

Orientadora: Profa. Dra. Maria Elenita Menezes Nascimento

Brasília-DF

Julho, 2015 


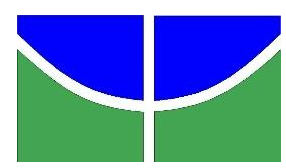

Universidade de Brasília

Centro de Excelência em Turismo

Mestrado Profissional em Turismo

\title{
Construção do Conhecimento do Turismo: competências necessárias para o exercício da profissão do Turismólogo
}

\author{
Tamara Silva Nicolau
}

Orientadora: Profa. Dra. Maria Elenita Menezes Nascimento

Dissertação apresentada ao Mestrado Profissional em Turismo da Universidade de Brasília como requisito parcial para obtenção do título de mestre.

Brasília-DF

Julho, 2015 


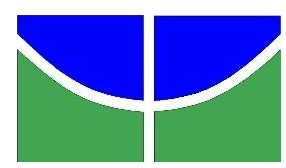

Universidade de Brasília

Centro de Excelência em Turismo

Mestrado Profissional em Turismo

\title{
Construção do Conhecimento do Turismo: competências necessárias para o exercício da profissão do Turismólogo
}

\author{
Tamara Silva Nicolau
}

Banca Examinadora:

Orientadora Profa. Dra. Maria Elenita Menezes Nascimento

Examinador: Prof. Dr. Neio Lucio de Oliveira Campos - membro

Examinador: Prof. Dr. João Paulo Faria Tasso - membro

Examinador Dr. Luiz Carlos Spiller Pena - membro suplente 
Ficha catalográfica elaborada automaticamente, com os dados fornecidos pelo(a) autor(a)

S639c Silva Nicolau, Tamara

Construção do Conhecimento do Turismo:

competências necessárias para o exercício da profissão do Turismólogo / Tamara Silva Nicolau; orientador Maria Elenita Menezes Nascimento. Brasília, 2015.

$109 \mathrm{p}$.

Dissertação (Mestrado - Mestrado Profissional em Turismo) -- Universidade de Brasília, 2015.

1. Turismólogo. 2. Competências. 3. Construção do Conhecimento. 4. Interdisciplinaridade. 5. Ensino do Turismo. I. Menezes Nascimento, Maria Elenita, orient. II. Título. 


\section{DEDICATÓRIA}

Dedico este trabalho ao meu sobrinho Vicente,

em quem busquei o sorriso

para a inspiração, o alento e a persistência. 
A alegria não chega apenas no encontro do achado, mas faz parte do processo da busca. E ensinar e aprender não pode dar-se fora da procura, fora da boniteza e da alegria.

Paulo Freire 


\section{AGRADECIMENTOS}

À querida orientadora Profa. Dra. Maria Elenita M. Nascimento, por ter aceito o desafio desta orientação e pela compreensão, sabedoria e palavras sempre positivas e de incentivo, que me permitiram prosseguir e concluir esse estudo.

À minha família toda pela confiança e pelo amor sempre presente. Especialmente aos meus pais Rosangela e Victor, avós Adelina e Nereu, meu irmão Digo, meus dindos Jussara e Sady e meu primo Sadisinho.

Aos meus amigos de longe e de perto, que souberam compreender a ausência e incentivar com palavras e carinho. Em particular às queridas Márcia, Cris e Kate por serem grandes torcedoras de todas as minhas empreitadas.

Aos amigos amados Lila e Bruno, que ainda em Floripa, antes mesmo da minha decisão final, foram essenciais com a presença e estímulo. E ao Rafa, que sempre trouxe uma visão positiva do futuro pós-mestrado.

Aos queridos Naninha, Joara e Maurício que me receberam tão bem aqui em Brasília e fizeram esta cidade muito mais acolhedora do que o esperado.

Aos amigos do Kzao por este ano incrível de aprendizado e convivência. Pelas minhas horas de isolamento tão bem compreendidas e respeitadas. Um muito obrigada especial ao Lucas, pela atenção, bom humor, paciência, risadas e parceria que fizeram a reta final ser bem mais leve, feliz e produtiva.

Aos companheiros de trabalho, especialmente Ju, Thiago e Josi, pela oportunidade recebida, a qual me propiciou a realização deste mestrado.

Aos colegas do mestrado pelas angústias divididas e pelos momentos de pausa e diversão que nos aproximaram.

Aos queridos professores Dra. Marutschka M. Moesch, Dra. Iara Brasileiro e Dr. Neio Campos, por terem sido parte importante na construção deste projeto. Seus conhecimentos tão bem compartilhados foram essenciais nesta trajetória.

Finalmente, aos anjos, espíritos de luz e de boas energias que caminharam ao meu lado, me trazendo alento e persistência para continuar. 


\section{RESUMO}

A pesquisa teve como objetivo traçar a relação entre o conhecimento acadêmico do bacharel em turismo e a prática do exercício da profissão. Buscou-se investigar as relações entre os conteúdos teóricos desenvolvidos nos cursos de bacharelado em Turismo e o exercício da profissão do turismólogo e se os cursos de bacharelado em turismo no Brasil estão em conformidade com as condições requeridas para o exercício da profissão. O parâmetro para direcionar a pesquisa utiliza-se do conceito de competências, visto sob a ótica da academia e dos turismólogos que tenham o turismo como atividade profissional. Trata-se de uma investigação de como o ensino superior do turismo vem se desenvolvendo e como a questão das competências é abordada na estrutura curricular. É apresentado um breve histórico global e nacional do ensino superior de turismo e também o caráter interdisciplinar do ensino do turismo. A metodologia utilizada é a pesquisa bibliográfica sobre o tema. Uma entrevista qualitativa foi realizada junto a trinta turismólogos e quinze coordenadores de cursos de bacharelado em turismo. Como resultado conclui-se que os cursos de bacharelado em turismo passam por etapas distintas de concepção desde seu surgimento e que se encontram em um período de valorização acadêmica e de reformulações buscando maior adaptação às realidades onde estão inseridos.

Palavras-chave: Construção do Conhecimento; Interdisciplinaridade; Turismólogo; Competências; Ensino do Turismo. 


\begin{abstract}
The objective of the research is to describe the connexion between academic knowledge of bachelor of tourism and the practice of their profession. It seeks to investigate whether or not tourism bachelor's degree programs in Brazil are in accordance with the conditions required for the exercise of specialist tourism profession. The parameter to direct the research uses the concept of competence, seen from the perspective of the academy and tourism specialist that have tourism as activity. It is an investigation of how bachelor's degree in tourism is developing and also the interdisciplinary feature of tourism education appears in the curriculum. It's presented a brief global and national history of higher tourism education and also the interdisciplinary feature of tourism education. The methodology used was bibliographic research and a survey with tourism specialists and bachelor's coordinators in tourism. As a result it is concluded that tourism bachelor's go through different stages of conceptual development from its appearance in Brasil and are in a period of academic appreciation and reformulations for a better adaptation to local realities.
\end{abstract}

Key words: Construction of knowledge; Interdisciplinarity; Tourism specialist; Skills; Tourism teaching. 


\section{SUMÁRIO}

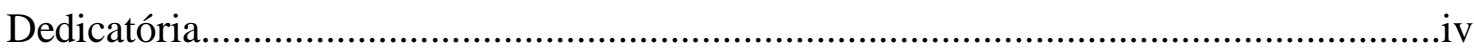

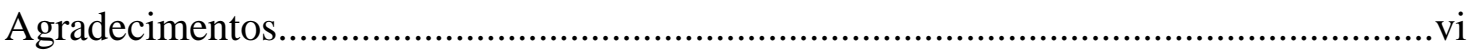



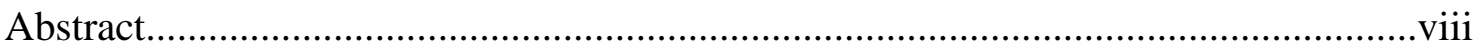

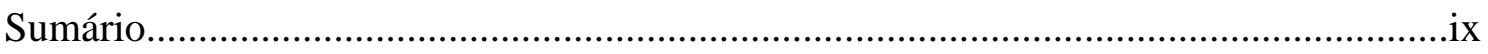

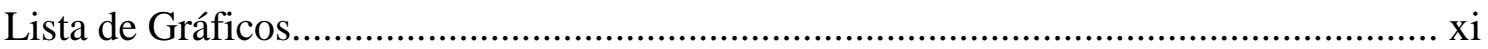

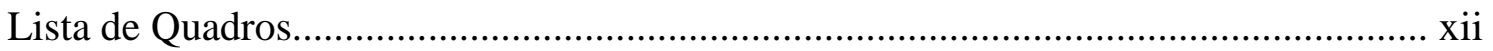

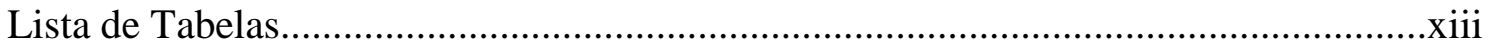

Lista de Siglas e Abreviaturas..................................................................................

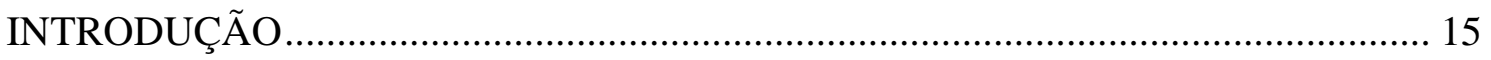

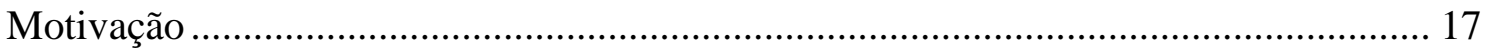

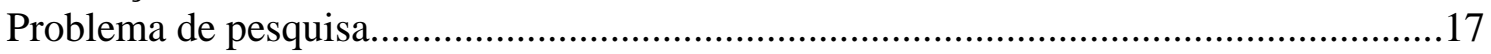



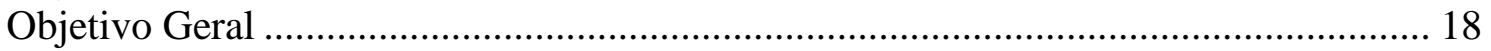



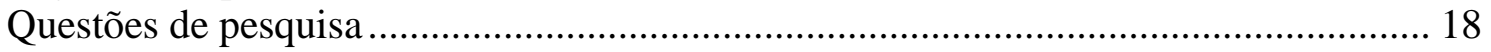

1.CONTEXTUALIZAÇÃO HISTÓRICA DO ENSINO DE TURISMO ..................... 19

1.1 Breve histórico do ensino do Turismo ............................................................................. 19

1.2 Breve histórico do ensino do turismo no Brasil ...............................................................29

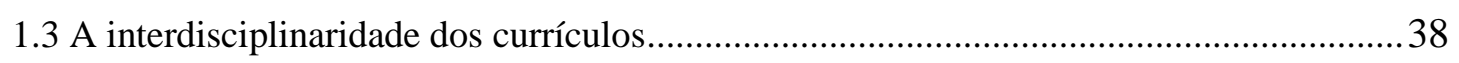

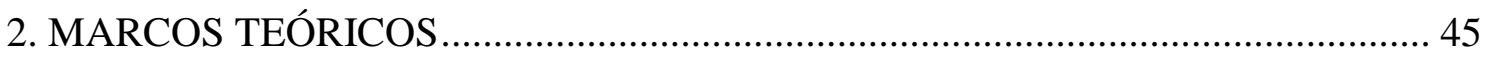

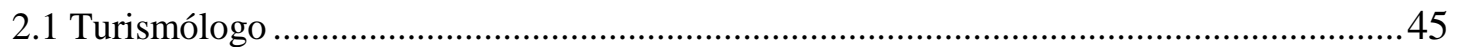

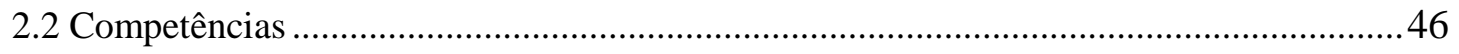



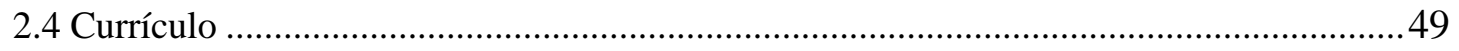

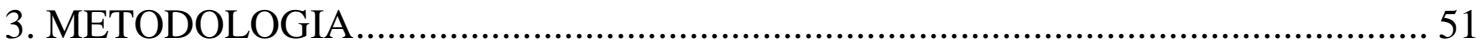

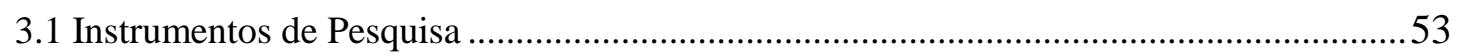

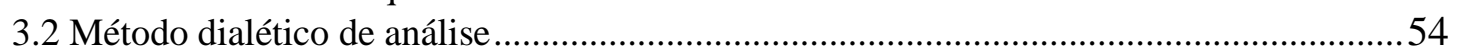

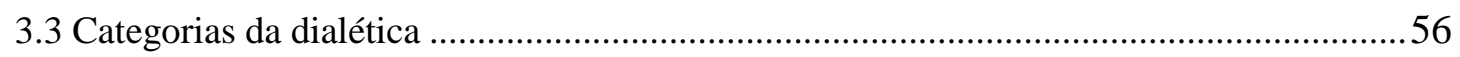

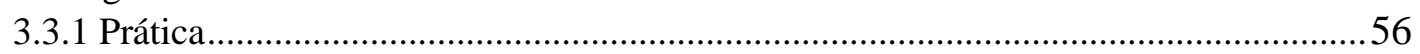

3.3.2 Totalidade

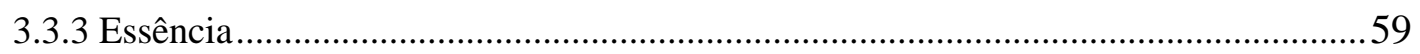

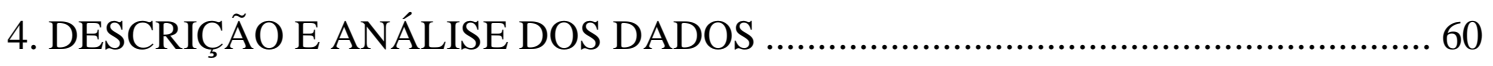

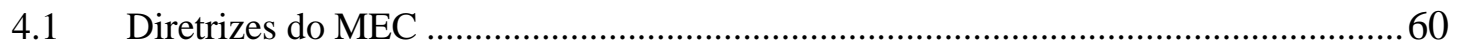

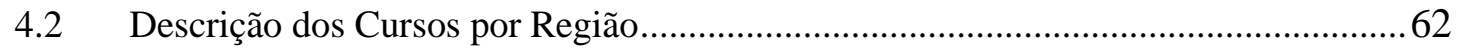





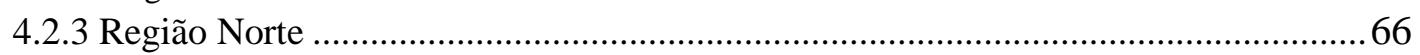

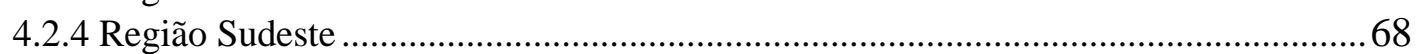

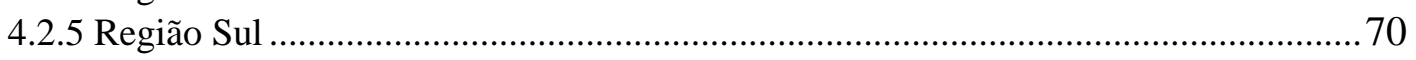

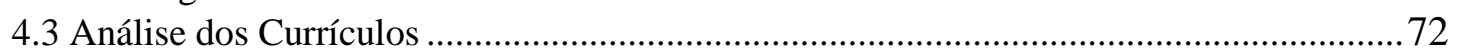

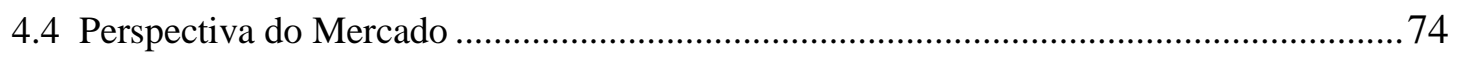

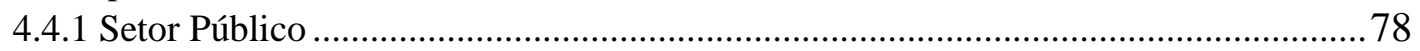




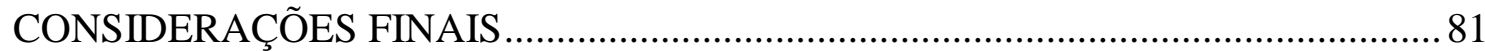

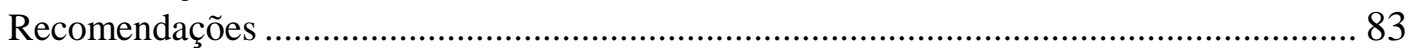



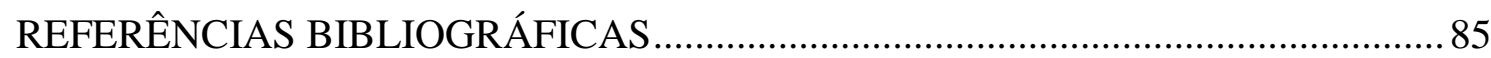

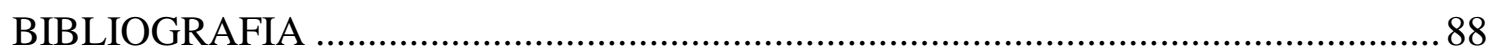

ANEXOS

Anexo A_Resolução n ${ }^{\circ}$ 13, de 24 de novembro de 2006 (*)....................................... 90

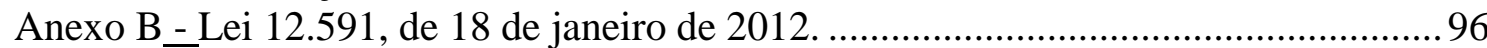

Anexo C_Edital ESAF n ${ }^{\circ} 79$, de 06 de dezembro de 2013 .......................................... 98

Anexo D_Embratur - Instituto Brasileiro de Turismo_Edital no 1 de 5 de novembro de 2010.

APÊNDICES

APÊNDICE A_QUESTIONÁRIO PARA OS COORDENADORES DE CURSO ... 104 APÊNDICE B_QUESTIONÁRIO PARA EGRESSOS DE CURSOS DE TURISMO 


\section{LISTA DE GRÁFICOS}

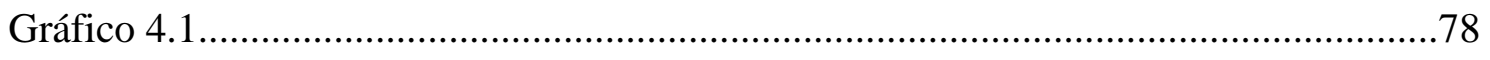




\section{LISTA DE QUADROS}

Quadro 1.1 Orientação da investigação turística por regiões..........................................28

Quadro 1.2 Currículo mínimo do MEC - Resolução s/n. de 28 de janeiro de 1971.........39

Quadro 1.3 Proposta de currículo mínimo da Comissão de Currículos e Programas do III

ENBETUR (1981).

Quadro 1.4 Proposta de currículo mínimo da EMBRATUR (1981)................................41

Quadro 1.5 Proposta de currículo mínimo da ABBTUR (1995).......................................41

Quadro 1.6 Proposta de currículo mínimo da ABBTUR e ABDETH..............................42

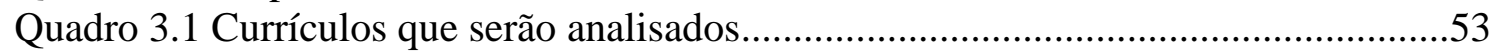

Quadro 4.1 Cursos da Região Centro Oeste.......................................................................63



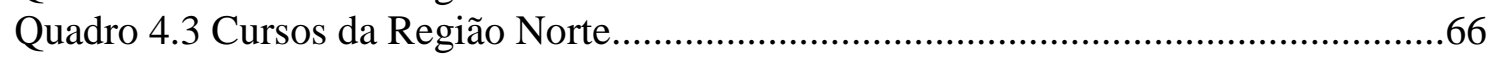

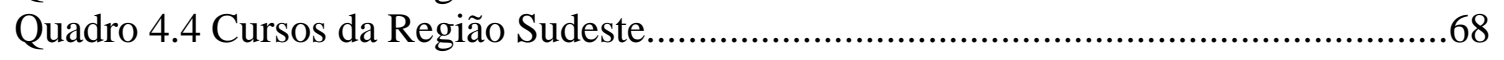

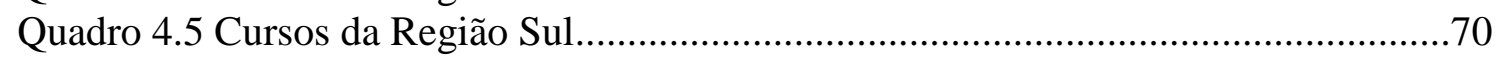




\section{LISTA DE TABELAS}

Tabela 1.1 - Crescimento dos cursos de turismo/hotelaria no Reino Unido....................23 


\section{LISTA DE SIGLAS E ABREVIATURAS}

$\begin{array}{ll}\text { ABBTUR } & \text { Associação Brasileira de Turismólogos e Profissionais do Turismo } \\ \text { ABDETH } & \text { Associação Brasileira de Dirigentes de Escolas de Turismo e Hotelaria } \\ \text { CAPES } & \text { Coordenação de Aperfeiçoamento de Pessoal de Nível Superior } \\ \text { CESTUR } & \text { Centro de Estudos Superiores de Turismo } \\ \text { CET } & \text { Centro de Excelência em Turismo } \\ \text { CICATUR } & \text { Centro Interamericano de Capacitação Turística } \\ \text { CIEST } & \text { Centro Internacional de Estudos Superiores em Turismo } \\ \text { EMBRATUR } & \text { Instituto Brasileiro de Turismo } \\ \text { ENBETUR } & \text { Encontro Nacional de Bacharéis e Estudantes de Turismo } \\ \text { IFT } & \text { Instituto de Formação Turística } \\ \text { IITTM } & \text { Instituto Indiano de Turismo e Gestão de Viagens } \\ \text { MEC } & \text { Ministério da Educação } \\ \text { PROUNI } & \text { Programa Universidade para Todos } \\ \text { SECTUR } & \text { Secretaria de Turismo do México } \\ \text { SENAC } & \text { Serviço Nacional do Comércio } \\ \text { SENAI } & \text { Serviço Nacional da Indústria } \\ \text { UNWTO } & \text { Organização de Turismo Mundial das Nações Unidas } \\ \text { UPIS } & \text { União Pioneira da Integração Social } \\ \text { UnB } & \text { Universidade de Brasília }\end{array}$




\section{INTRODUÇÃO}

A relação entre o conhecimento acadêmico do turismólogo e sua prática profissional é o caminho que direciona o presente estudo que busca compreender as conexões entre teoria e prática, o que é um desafio motivador. Como o Turismólogo, profissional com formação superior em Turismo, considera-se nesta pesquisa.

A inquietação que levou a esta pesquisa teve origem na vivência profissional da pesquisadora na atividade turística, iniciada no período de graduação. A partir da atuação em diferentes segmentos do turismo, foi possível perceber que o turismólogo é um profissional que deve apresentar qualificações e competências técnicas, operacionais e humanas para o pleno exercício de sua profissão.

A pesquisa pretende investigar como o ensino superior do turismo vem se desenvolvendo e como é tratada a questão das competências na estrutura curricular. Além disso, propõe analisar o efetivo exercício da profissão, fazendo a conexão da atividade profissional com a academia.

O tema proposto irá tratar das competências necessárias ao turismólogo para o exercício da profissão e sobre a construção destas competências no percurso da formação acadêmica.

Na última década houve um crescimento dos estudos e pesquisas relacionados à educação superior em turismo. Estas investigações, conforme Cervera e Ruiz-Molina (2008, apud BUSTELO; FERNANDES; TOMÁS, 2010, p.1193, tradução nossa) é resumido em cinco áreas principais de pesquisa que são: Primeiro a falta de consenso sobre o conteúdo dos currículos de turismo, sendo que há um debate sobre o que teria mais peso na construção das habilidades cognitivas para a atuação profissional: os conhecimentos gerais ou as disciplinas específicas. A segunda área de pesquisa traz estudos que tratam das consequências da mobilidade do trabalho no turismo. O terceiro ponto estudado é o das ligações informais entre a atividade turística e a pesquisa acadêmica, o que dificulta a transferência de conhecimento. As pesquisas que tratam sobre a importância e implementação de uma educação cooperativa nos estudos do turismo apresentam uma quarta área de análise. O quinto tema são os estudos sobre a necessidade de um debate internacional das questões educacionais do turismo. Nesta pesquisa o foco se dará nas questões curriculares e na formação de competências, sendo feita a ligação entre educação e trabalho. 
Visando o alcance dos objetivos da pesquisa o presente trabalho será dividido em quatro capítulos. No primeiro capítulo será apresentado um breve histórico do percurso dos cursos superiores em turismo e também será abordada a questão da interdisciplinaridade dos currículos.

No segundo capítulo serão apresentados os principais aportes teóricos que auxiliam na construção da pesquisa. Neste capítulo realiza-se a revisão da literatura, apresentando as abordagens a respeito da profissão do turismólogo, das competências e do ensino do turismo.

O terceiro capítulo trata da trajetória metodológica. A pesquisa utilizou o método dialético histórico-estrutural. Referente à formação do turismólogo o estudo foi realizado a partir dos cursos de bacharelado criados nos últimos 15 anos. Para esta análise foram pesquisados currículos dos cursos superiores de turismo em instituições de ensino reconhecidas das diferentes regiões do Brasil. Para isto foi utilizada a pesquisa bibliográfica, de documentos e também de relatos de coordenadores dos cursos estudados. Para a análise da atuação profissional foram reunidos os relatos de profissionais da atividade turística e que tenham a formação em Turismo.

O quarto capítulo apresentará o resultado da coleta dos dados realizada iniciando-se com as Diretrizes Curriculares instituídas pelo Ministério da Educação. Posteriormente, são descritos e analisados os cursos por região e apresentados os resultados dos questionários aplicados junto aos coordenadores dos cursos pesquisados e aos profissionais atuantes na atividade turística. Finalmente, são apresentados os descompassos e convergências entre o conteúdo e a prática do exercício da profissão de turismólogo.

Nas Conclusões são apresentadas três seções: a primeira, referente às considerações finais. Na segunda são apresentadas as principais recomendações e a terceira, os desenvolvimentos futuros.

A partir deste estudo pretende-se traçar uma linha de conexão entre academia e atividade profissional do turismo, como também tecer algumas considerações que auxiliem a construção do conhecimento na busca de melhoria da qualificação profissional. 


\title{
Motivação
}

O currículo dos cursos superiores de turismo é motivo de debates em torno de seu objeto de estudo central e está presente em pesquisas realizadas por estudiosos da área, como Sérgio Molina, Marutschka Moesch, Mirian Rejowski, John Tribe. No entanto, de maneira geral, os estudos realizados estão centrados na questão curricular sem uma conexão com o mundo do trabalho. Considera-se importante a análise do escopo teórico dos cursos de turismo no sentido de avançar para uma maior qualificação acadêmica, mas o que se investiga nesta pesquisa é a relação de causalidade entre a o mundo acadêmico e a prática do mundo do trabalho. Desta forma, acredita-se que uma visão atenta a atividade do turismo a partir da atuação profissional pode ser uma combinação positiva para uma qualificação mais plena nos cursos superiores.

\begin{abstract}
A conjugação dos TEMPOS vivenciais diferenciados, em espaços cada vez mais unos, favorece a convivência física entre as pessoas e a vivência com intensidade das inter-relações, em praias massificadas ou em bucólicos recantos rurais, e requer novas reflexões e teorias explicativas para uma melhor atuação dos bacharéis em Turismo, no processo de planejamento. As novas práticas turísticas requerem uma nova práxis turística. (MOESCH, 2002, p. 26)
\end{abstract}

Além de se dedicar ao caráter acadêmico da formação do turismólogo, a pesquisa busca ainda esclarecer como a formação pode contribuir para um crescente reconhecimento da profissão pelo próprio turismólogo, levando à sua realização profissional.

\begin{abstract}
Mas aquilo que caracteriza propriamente a consciência é o pensar em relação à realidade, ao conteúdo — a relação entre as formas e estruturas de pensamento do sujeito e aquilo que este não é. Este sentido mais profundo de consciência ou faculdade de pensar não é apenas o desenvolvimento lógico formal, mas ele corresponde literalmente à capacidade de fazer experiências. Eu diria que pensar é o mesmo que fazer experiências intelectuais. Nesta medida e nos termos que procuramos expor, a educação para a experiência é idêntica à educação para a emancipação. (ADORNO, 1995, p. 151)
\end{abstract}

\section{Problema de pesquisa}

O turismo é uma atividade que pode ter caráter econômico, de prestação de serviços, lazer ou hospitalidade. Independentemente do segmento, na atividade turística está presente de um lado a demanda do mercado e de outro os anseios do profissional.

Sendo assim, pretende-se responder como a formação acadêmica pode contribuir para a construção de competências que atendam às solicitações do mundo do trabalho e que auxiliem o turismólogo a consolidar o valor social da sua profissão. 


\section{Objetivos}

O estudo terá os seguintes objetivos:

Objetivo Geral

Investigar a relação entre as competências trabalhadas na formação acadêmica e as aptidões requisitadas pelo mundo do trabalho contemporâneo.

\section{Objetivos Específicos}

- Analisar a estrutura curricular dos cursos de formação superior em turismo existentes em 5 (cinco) regiões brasileiras;

- Analisar se as Diretrizes Curriculares Nacionais do Curso de Graduação em Turismo instituídas pelo MEC são formadoras de conhecimento e geram competências para o efetivo exercício da profissão;

- Levantar as atividades necessárias ao exercício da profissão do turismólogo a partir da Classificação Brasileira de Ocupações, do Ministério do Trabalho e Emprego e da Lei 12.591, de 18/01/2012;

- Levantar junto às empresas públicas e privadas suas percepções sobre as competências necessárias para o exercício da profissão;

- Analisar se a formação acadêmica desenvolve as competências necessárias ao exercício da profissão.

\section{Questões de pesquisa}

- A organização curricular dos cursos superiores de turismo é suficiente para a formação das competências (recursos cognitivos saberes, capacidades) necessárias ao exercício da profissão?

- As diretrizes curriculares propostas pelo MEC contribuem para a formação das competências necessárias ao exercício da profissão?

- A interdisciplinaridade presente nos cursos de turismo é suficiente para a formação do conhecimento necessário ao exercício da profissão? 


\section{CONTEXTUALIZAÇÃO HISTÓRICA DO ENSINO DE TURISMO}

Com o fim de possibilitar uma compreensão do modelo de formação que está presente hoje nos cursos superiores de turismo é importante entender como estes cursos surgiram e se desenvolveram ao longo do tempo. Neste capítulo será apresentado um breve relato do trajetória histórica percorrida pelos cursos superiores de turismo.

Atualmente os cursos de formação superior em turismo apresentam uma estrutura curricular que foi construída no decorrer do tempo, sendo transpassada por características do cenário social, econômico e cultural dos períodos em que os currículos dos cursos foram criados e também de quando foram feitas suas reestruturações.

Com a finalidade de analisar a estrutura curricular dos cursos de formação superior em turismo, resgatar este trajeto histórico será importante para atingir a compreensão do porque dos cursos terem os modelos de currículos atuais. Esta análise buscará entender o modelo curricular vigente está compatível com as atuais demandas das dimensões acadêmicas e profissionais.

\subsection{Breve histórico do ensino do Turismo}

Bem antes da origem dos cursos de turismo, a atividade turística se fazia presente e era utilizada como mecanismo para fortalecer o poder das ideias dominantes. Como exemplificação tem-se o caso da Itália:

\footnotetext{
Entretanto, o turismo, na medida em que exalta as belezas de um lugar, sejam elas naturais ou culturais, pode ser uma ferramenta a serviço da ideologia dominante, como foi demonstrado na década de 1930 por Mussolini na Itália, onde as colônias de férias foram utilizadas para difundir o ideário fascista. (BARRETO; TAMANINI; DA SILVA, 2004, p. 54)
}

Neste período, contudo, a atividade turística era realizada muito mais de forma intuitiva e sem planejamento. A atividade se desenvolvia naturalmente, sem uma perspectiva e organização profissional. No entanto, a partir do entendimento da necessidade de profissionais capacitados e de qualificação na prestação dos serviços turísticos, iniciou-se também a preocupação em oferecer a formação necessária para estes profissionais. 
O campo de ensino e pesquisa sobre o turismo é recente, se comparado à outras áreas de estudo que também não são tradicionais. E no que diz respeito à evolução dos cursos de turismo, há diferenças na forma como estes foram conduzidos e se adaptando de acordo com a realidade dos países onde se implementavam.

Há, no entanto, um padrão geral no qual a educação em turismo se desenvolveu e que influencia a formatação dos cursos atuais. Segundo Cooper, Shepherd e Westlake (2001, p. 28-29), a educação em turismo se desenvolveu a partir de três formas diferentes: cursos vocacionais, direcionados ao treinamento; cursos voltados à gestão ou aplicação industrial e os cursos desenvolvidos como especialização dentro de disciplinas mais tradicionais, tais como geografia e sociologia.

Iniciando pela Europa, de acordo com Formica (1996, p. 317, tradução nossa), o turismo era considerado uma atividade meramente econômica, com possibilidades lucrativas. Desta forma, o ensino inicial voltado ao setor do turismo visava apenas a preparação técnica e para suprir a demanda por profissionais para cargos operacionais. Neste contexto prevalecia a visão do turismo como uma indústria. Esta visão restringia os programas dos cursos à habilidades técnicas, sem uma preocupação com os conhecimentos gerais e mais amplos que envolvessem o entendimento do contexto cultural e social da época.

Apenas a partir do final da década de 70, com o surgimento de novos destinos teve início na Europa a oferta de qualificação aos profissionais do turismo.

\footnotetext{
Consequentemente, os hoteleiros e agentes de viagens foram forçados a ter uma melhor compreensão sobre as forças ambientais que foram moldando o turismo e indústria de viagens e transformaram o mercado hoteleiro em um mercado altamente competitivo. Uma sólida formação em gestão da hospitalidade se tornava um requisito fundamental para os gestores a fim de ter sucesso no complexo mercado de turismo e hospitalidade. (FORMICA, 1996, p. 317, tradução nossa).
}

Somente a partir da década de 80 é que começam a ser oferecidos os cursos de bacharelado em turismo na Europa. Devido a diversidade dos países europeus, o desenvolvimento dos cursos se deu de diferentes formas nos países. O tempo de duração dos cursos e estrutura dos currículos não era padrão e estes quesitos foram implementados de maneiras diversas de acordo com os países.

Na Alemanha, de acordo com Formica (1996, p. 318, tradução nossa), os cursos de turismo no nível de bacharelado iniciaram com a duração de oito semestres. Já o ensino que era oferecido nos cursos de Geografia, Economia Política e Administração, era considerado uma especialização dentro destes cursos e tinha duração de um ou dois 
semestres. Nesta época, já se revela o caráter interdisciplinar do turismo, visto que pode ser acolhido dentro de diferentes cursos e comunicar-se com os mesmos.

A educação em turismo é relativamente nova na Alemanha e, enquanto a educação vocacional inicial em nível de assistente está bem estabelecida, foi apenas no final da década de 70 que cursos avançados para gerenciamento em turismo se tornaram disponíveis (COOPER; SHEPHERD; WESTLAKE, 2001, p.123).

A Suíça foi um dos primeiros países da Europa a desenvolver cursos de turismo dentro das faculdades de negócios. A Universidade de Berna tem um Departamento de Economia do Turismo em sua Faculdade de Comércio e Economia. (FORMICA, 1996, p. 318, tradução nossa).

No Centro Internacional de Glion os professores e colaboradores desenvolviam uma atividade de direção e gestão que oferecia aos alunos o contato com a experiência prática continuamente atualizada. Este Centro também criou instalações para serviços receptivos de turismo e de restauração, demonstrando a interdependência entre a teoria e a prática.

Tais instalações constituem uma garantia para a atualização contínua da formação de pessoal, proporcionando aos jovens estudantes não só conhecimentos tecnológicos, mas também desenvolvendo neles o espírito profissional que os torna capazes de adaptarem-se às exigências da realidade. Esse é o "espírito" de Glion. (BENI, 1992, p. 15)

Os cursos de turismo da Espanha, de acordo com estudo da Universitat de Lês Illes Balears (s.d., p.17 apud Barreto, Tamanini e da Silva, 2004. p.51):

(...) balizaram os cursos do Brasil, oferecem vários níveis de formação e currículos flexíveis, com um mínimo de $30 \%$ de disciplinas de livre escolha dos alunos de forma a possibilitar uma formação específica para os setores de hotelaria, agências, companhias aéreas e outras áreas relacionadas com a prestação de serviços e instalações turísticas, atendendo ao objetivo da universidade de propiciar um maior grau de especialização conforme a necessidade detectada na região onde o curso é ministrado.

Neste país o ensino de turismo foi regulamentado na década de 80 e a característica dos cursos era de uma formação polivalente, sendo direcionada principalmente para cargos técnicos e de gestão de agências de viagens e hotéis e guias turísticos. Especializações podem ser obtidas nos cursos de pós-graduação. No final da década de 80, os cursos de turismo na Espanha passaram por uma revisão que tinha o objetivo de aumentar a qualidade dos mesmos. Entre as questões discutidas nesta revisão, considera-se que ainda são atuais e que podem ser pensadas em relação aos 
cursos contemporâneos. Como destaque entre as questões colocadas em discussão listam-se as seguintes:

c) os conteúdos dos programas de estudos precisam atender ao contínuo processo de modernização na tecnologia das comunicações e o rápido ritmo de mudança nas características do turismo e dos turistas; além disso, devem estar compatibilizados com exigências de formação especializada em administração empresarial moderna, com ênfase na particularidade da gestão de empresas turísticas específicas; compete aqui aos empresários uma contribuição maior, proporcionando informações detalhadas sobre as ocupações específicas de nível técnico e de direção existentes nas empresas, os conhecimentos e capacidades que demandam ou que vão exigir no futuro imediato e suas políticas de recrutamento de pessoal;

d) formação teórica e prática, em termos de duração, conteúdo e condições da prática;

e) as características dos centros de formação, visando reforçar o modelo atual de escolas de nível superior independentes ou incluir os cursos de turismo na Universidade;

f) a colaboração de empresários e de profissionais na revisão dos cursos de turismo. (BENI, 1992, p. 11-12)

Na França foi criado em 1961 o Centro de Estudos Superiores de Turismo na Faculdade de Letras e Ciências Humanas de Paris. Para algumas atividades específicas, como guias, recepcionistas a formação era feita no ensino secundário ou em escolas profissionais de nível pré-universitário. Os cursos superiores de turismo na França apresentam características de multidisciplinaridade, internacionalização, motivação dos estudantes, adaptabilidade, mobilidade e alternância entre teoria e prática, parceria com as empresas turísticas, pesquisas. (BENI, 1992, p. 12-13)

Nos anos 60 surgiram os cursos de turismo na Holanda e na Bélgica. Segundo Beni (1992, p. 13), os Países Baixos têm cursos superiores nas áreas de turismo, recreação e lazer. A educação em nível superior iniciou-se em 1964, com a criação do Instituto Holandês para Estudos de Turismo, Lazer e Transporte, em Breda.

$\mathrm{Na}$ Itália, apesar da presença de grandes pensadores do turismo, o país aparentemente passava pela mesma complexidade de se estabelecer um modelo de currículo para os cursos de turismo.

Nesse país, que congrega alguns dos maiores pesquisadores e teóricos do turismo, a questão do ensino superior ainda busca sair de suas especificidades regionais e até locais para atingir uma generalidade nacional, ainda que não completa (BENI, 1992, p. 14).

O país seguia um rumo contrário ao cenário mundial e europeu. A disciplina de economia do turismo não era regular em suas faculdades. $\mathrm{O}$ estudo da economia era oferecido em cursos mais específicos, como o curso de Especialização em Economia do 
turismo, da Faculdade de Economia e Comércio da Universidade de Florença, criado em 1963. Na busca por uma base para o ensino do turismo, a Itália iniciou o caminho na teoria sistêmica para atender aos requisitos atuais de formação e capacitação dos profissionais em turismo. (BENI, 1992, p.14-15)

Na década de 90 a Polônia criou um programa de gestão de turismo com dois anos de duração, denominado Programa para o Desenvolvimento do Turismo na Polônia. Este programa era tecnicamente mantido por uma consultoria de uma empresa Espanhola. (AIREY, 1994 apud FORMICA, 1996, p. 318, tradução nossa).

Uma das surpresas da pesquisa foi a descoberta, conforme Rakadjiyska (1990, apud FORMICA, 1996, p. 318) de que a Bulgária oferecia cursos de hospitalidade e turismo desde a metade da década de 60, seguindo na contramão dos outros países europeus que foram se alertar para estes cursos apenas nas décadas seguintes.

No Reino Unido o curso de turismo inicialmente estava presente apenas nas pósgraduações num período que durou mais de 20 anos. $\mathrm{O}$ início dos cursos de graduação no Reino Unido data de 1986 (TEIXEIRA, FLETCHER, WESTLAKE, 2000, p. 19). Nesta região da Europa a propagação dos cursos de graduação em turismo também se deu de forma rápida, conforme mostrado na Tabela 1.1 a seguir:

TABELA 1.1 - Crescimento dos cursos de turismo/hotelaria no Reino Unido

\begin{tabular}{lllll}
\hline Instituições/Número de Cursos & $1991 / 2$ & $1993 / 4$ & $1995 / 6$ & $1997 / 8$ \\
\hline Instituições oferecendo cursos & 15 & 36 & 43 & 50 \\
$\begin{array}{l}\text { Número de cursos oferecidos na } \\
\text { graduação }\end{array}$ & 22 & 53 & 75 & 99 \\
$\begin{array}{l}\text { Número de cursos oferecidos na pós- } \\
\text { graduação }\end{array}$ & 12 & 27 & 42 & 66 \\
\hline
\end{tabular}

Fonte: AIREY e JOHNSON (1998) apud TEIXEIRA; FLETCHER; WESTLAKE, 2000, p. 19.

Como se pode verificar na Tabela 1.1 o rápido crescimento dos cursos de turismo/hotelaria levou a realização de pesquisas com o intuito de entender qual era o perfil destes cursos, de acordo com Busby e Fiedel (2001, p.502, tradução nossa).

O primeiro estudo desta natureza foi realizado em 1991/92 e nestes estudos a questão do rigor acadêmico é uma das preocupações que foram levantadas. Segundo Airey (1999 apud BUSBY e FIEDEL, 2001, p.502, tradução nossa), havia uma suspeita de que o rápido crescimento dos cursos tinha sido na forma de programas populares que 
tinham não apenas a carência de rigor, mas que seguidamente eram considerados superficiais e sem desafios.

A razão para a criação dos cursos de turismo no Reino Unido se assemelha bastante à dos outros países da Europa. Inicialmente os cursos foram concebidos para atender a demanda local ou regional, da indústria ou do governo e demanda dos estudantes (TEIXEIRA; FLETCHER; WESTLAKE, 2000, p. 20). No Reino Unido, de certa forma, a partir da criação dos cursos de turismo, já se iniciava a discussão em torno de quais seriam as competências a serem trabalhadas nestes cursos. $\mathrm{Na}$ época de surgimento dos cursos no Reino Unido havia diversas visões, como a necessidade de qualificar os cargos de gerência, na concepção de indústria; a noção de que os graduados em turismo iriam competir com profissionais de outras áreas; a diversidade da indústria como dificuldade para a criação de cursos voltados a um setor específico; a falta de compreensão pela indústria do profissional que é formado devido aos cursos serem muito recentes (TEIXEIRA; FLETCHER; WESTLAKE, 2000, p.22-23).

O conflito sobre as competências e habilidades desejáveis ao profissional de turismo estava presente não só na academia, como também no mercado de trabalho do Reino Unido. De acordo com algumas universidades pesquisadas, havia o entendimento da existência de um gap inevitável entre o profissional formado e o modelo de gerente que a indústria desejava. Outras universidades consideravam não existir este problema e entendiam que os profissionais seriam julgados por suas ações. E outras universidades, afirmavam ainda que o problema estava na indústria por ser muito diverso e não se saber exatamente o tipo de profissional que buscava (TEIXEIRA; FLETCHER; WESTLAKE, 2000, p.33-34). Cabe ressaltar que prevalecia a concepção de indústria da atividade turística.

A Turquia pode-se dizer que é um caso de sucesso no nível de colocação e aproveitamento profissional dos egressos dos cursos de turismo. De acordo com Barreto, Tamanini e da Silva (2004, p. 45), uma pesquisa realizada demonstra que grande parte dos egressos está trabalhando na área e há também uma grande satisfação pela maioria dos estudantes em relação ao curso realizado. Isto se deve muito ao fato de haver no país um reconhecimento e valorização dos cursos de turismo por parte do empresariado local. Como diz Collins (2002, p. 159 apud BARRETO, TAMANINI e DA SILVA, 2004, p. 45): 
Também os empresários de turismo têm um olhar diferente sobre os graduados, valorizando-os pela sua capacidade de trabalhar em equipe, de compreender a política gerencial, de ser mais empreendedores e de ter mais autoconfiança.

No cenário das Américas, o Canadá é um exemplo de onde o objetivo inicial dos cursos de turismo era o de suprir a demanda de mão de obra para tarefas operacionais. Mas ao longo do tempo foi se desenvolvendo outra visão e sentindo a necessidade de um estudo mais aprofundado da atividade turística, para que esta pudesse se desenvolver de maneira sustentável.

Segundo Ritchie (1990, p.127 apud BARRETO; TAMANINI; DA SILVA, 2004, p. 45): O contrário acontece no Canadá, onde há total clareza por parte do Estado e do trade sobre a "necessidade de pesquisa rigorosa como base para o bom desenvolvimento do turismo a longo prazo." Convicção que, para se formar, levou tempo e esforço por parte da universidade, dado que, como no Brasil, o trade canadense, chamado de industry, tinha, tradicionalmente, a visão de que a única possibilidade de fazer carreira na empresa turística era começando "de baixo" [...]

Os Estados Unidos tiveram o primeiro curso de turismo surgindo também por demanda de mercado. Os cursos de turismo neste país surgiram a partir dos cursos de hotelaria que já existiam desde a década de 20. No entanto, o primeiro curso de bacharelado em turismo iniciou somente em 1969 na Universidade de Michigan (BARRETO; TAMANINI; DA SILVA, 2004, p.52). Uma característica dos cursos superiores em turismo nos Estados Unidos, segundo Cooper (2001, p. 122) é o fato de estarem inseridos como opção em cursos de gerenciamento de hospitalidade, em geral nas faculdades de administração. Desta forma, os cursos com direcionamento somente ao turismo, ainda são em quantidade reduzida.

No Peru, de acordo com Barreto; Tamanini; da Silva (2004, p.39), houve uma oferta muito grande de cursos de turismo ocasionando uma baixa no nível de qualidade dos cursos. Também há uma diversidade maior na segmentação dos cursos, como administração de empresas turísticas, bacharelado em comunicação e turismo e administração de empresas turísticas.

Os cursos de turismo na Argentina tiveram início com a formação tecnológica e depois passaram para os bacharelados e pós-graduações (BARRETO; TAMANINI; DA SILVA, 2004, p.39).

No México, conforme Nechar e Cortés (2006, p.90), os estudos de nível superior no turismo tiveram seu início na década de $70 \mathrm{com}$ a criação do Cicatur (Centro 
Interamericano de Capacitação Turística) e do Ciest (Centro Internacional de Estudos Superiores em Turismo). Na década de 80 foi criado o Cestur (Centro de Estudos Superiores de Turismo). No país havia uma dificuldade gerada pela divisão entre setor empresarial e educação, dificultando a qualificação dos profissionais atuantes na atividade turística. Esta situação não condizia com o potencial para o turismo que o país apresenta. Como diz Beni (1992, p. 17-18):

Ficou patente que a área de serviços precisava de capacitação e atualização profissional, sendo que o principal obstáculo para isso residia no próprio empresário (...). Outra questão é da formação dos próprios professores, bem como a ausência de definição de planos e programas para a atividade, visto que o México ainda vive a problemática da divisão entre a educação em turismo e o setor empresarial.

A quantidade de cursos superiores em turismo no México foi aumentando, sendo que até 2003 havia 209 instituições que ofereciam cursos de bacharelado e pósgraduação, de acordo com dados da SECTUR. No direcionamento dos cursos prevalecia a formação para atividades operacionais e gerenciais. A função social do turismo e a expansão de pesquisas na área ainda não tinham papel relevante.

\footnotetext{
É importante reconhecer o papel desempenhado pelas universidades e instituições de educação superior para se aproximar da área profissional turística, mas é necessário continuar trabalhando na análise do contexto social e nas necessidades educacionais, bem como nas condições que apresenta esta área profissional (SUÁREZ, 2004, p. 112, tradução nossa).
}

A Faculdade de Turismo da Universidade Autônoma do Estado do México é um exemplo de instituição que busca a formação integral. Nesta instituição existe a ideia de que o turismo é uma forma de educação para a compreensão das culturas diferentes e também para o desenvolvimento econômico e social.

(...) a primeira escola de turismo em nível universitário fundada no México, foi também pioneira a nível mundial ao considerar que o turismo está dotado de excepcional capacidade para promover o desenvolvimento regional, gerar empregos e como meio de educarmos para a aceitação das diversas culturas e sociedades da humanidade (VELÁSQUEZ, 2004, p. 138).

A partir dos anos 2000 cresce no país a importância e a preocupação com as políticas educacionais, as quais objetivam oferecer uma formação mais integral. Para isto, as novas diretrizes educacionais propunham o aumento dos níveis de qualidade da educação superior, com inovação, expansão do conhecimento científico, tecnológico, humanístico e artístico. 
Em relação à Colômbia vale destacar a quantidade considerável de cursos dedicados à formação em turismo e hotelaria na década de 80. Conforme menciona Beni (1992, p. 18): os dados sobre a Colômbia, embora divulgados em 1989, referem-se ao ano de 1983, quando existiam 27 institutos particulares e um público dedicado à formação superior em turismo e hotelaria.

No continente asiático, a Índia demonstra o interesse pelo ensino formal do turismo no final da década de 70. Em 1983 o Ministério do Turismo do país estabeleceu o Instituto Indiano de Turismo e Gestão de Viagens (IITTM) como uma sociedade para ensino e pesquisa em turismo e gestão de viagens. (SOFIQUE, p. 8, tradução nossa). Além do curso de gestão de viagens, o IITTM criou também cursos de curta duração em parceria com empresas privadas para a formação relacionada aos serviços auxiliares, como emissão de passagens e gestão de carga, por exemplo. No país há o entendimento de que o ensino em turismo não pode estar centrado apenas nas instituições que oferecem a formação em nível mais amplo. Está presente a ideia de que há setores específicos que merecem uma formação mais direcionada e segmentada.

As duas atividades mais importantes para o turismo são
acomodação/hospitalidade e a venda de viagens. Por isso, o
desenvolvimento profissional para a indústria do turismo não pode
limitar-se a educação em turismo e formação ministrada pelos
institutos e universidades a nível nacional apenas. Com este objetivo
em mente os planejadores de turismo na Índia, tanto no governo
quanto no setor privado, iniciaram institutos de Gestão Hoteleira,
Catering e Nutriçãa (SOFIQUE, p. 9-10, tradução nossa).

De qualquer forma, no contexto geral, a Índia enfrentou as mesmas dificuldades de outros países ao implementar os primeiros cursos voltados ao turismo. Havia a falta de professores e pesquisadores especializados na área, material didático e talvez o maior problema, a falta de compreensão do que é o turismo pelo lado do mercado e falta de interação entre o mercado e academia.

Na China encontra-se o Instituto de Formação Turística, instituição que recebeu o primeiro Certificado de TedQual (IFT). Esta certificação é concedida pela Organização de Turismo Mundial das Nações Unidas (UNWTO) e tem o objetivo de promover a melhora da qualidade dos programas de educação, formação e investigação em turismo (UNWTO). Na Oceania, os cursos de turismo na Austrália, de acordo com Lohman (2004, p. 251) surgiram na década de 70, no Footscray Institute of Technology.

Em relação ao estudo do turismo no âmbito global, o Quadro 1.1 mostra quais eram as principais linhas de pesquisa adotadas até o início dos anos 2000. De acordo com essas informações observa-se que no continente americano havia a predominância 
da questão econômica e de gestão. Verifica-se também que de maneira geral, nos outros continentes a preocupação estava focada nos impactos ambientais e culturais.

Quadro 1.1 Orientação da investigação turística por regiões

\begin{tabular}{|ll|}
\hline Regiões & Orientação \\
\hline Estados Unidos & Gestão Empresarial \\
Austrália e Nova Zelândia & Problemática ambiental e ecoturismo \\
Alemanha & Ócio e tempo livre \\
França & Impactos sobre a população \\
Croácia & Economia e planejamento turístico \\
Oriente Médio & Atos de terrorismo, insegurança, viagens turísticas \\
Índia & Impactos culturais e meio físico \\
Malásia & Impactos nas culturas autóctones \\
América Latina & Gestão empresarial \\
México & Capacitação, promoção, mercado e planejamento \\
\hline
\end{tabular}

Fonte: Nechar e Cortés, 2006, p. 88, tradução nossa.

No cenário mundial contemporâneo, o processo de verificação e adaptação dos currículos dos cursos de turismo é contínuo e talvez seja infindo e mutável de acordo com os novos cenários socioeconômicos, da mesma forma inconstantes. Conforme Sogayar e Rejowski (2011, p.283):

(...) percebem-se ajustes de propostas curriculares na primeira década do século XXI em face de demandas distintas na formação de profissionais qualificados. (...) A formação profissional para o setor, então, caminha ao lado do processo de internacionalização, e requer a compatibilização dos projetos educativos de diferentes países, direcionando-se para a formação das bases de um novo paradigma educacional.

Atualmente, o sistema de educação superior em turismo, particularmente na Europa, está passando por um processo de adaptação e mudanças para as novas exigências de um cenário global, caracterizadas por importantes mudanças no mercado de trabalho, aumento da competitividade global, avanços tecnológicos contínuos e mudanças nos padrões de demanda. (BUSTELO, FERNANDEZ e TOMÁS, p. 1192)

Desta forma, nota-se que há um movimento no sentido de adequar as estruturas curriculares ao contex to atual, levando em conta os anseios do novo modelo de mercado e da academia.

Verifica-se que o processo evolutivo do ensino superior em turismo no Exterior, em especial na Europa e nos Estados Unidos, acompanha a profissionalização do setor, que se inicia na área da hotelaria e depois 
em turismo, muito voltada aos negócios e ao desenvolvimento turístico, com ênfase na gestão. A forma como se processa essa educação se ajusta ao cenário de constantes mudanças no mundo contemporâneo, quer sejam de ordem econômica, quer de ordem social ou cultural. (SOGAYAR e REJOWSKI, 2011, p.285-286).

$\mathrm{Na}$ próxima seção será especificamente abordado o histórico dos cursos de turismo no Brasil e poderá ser verificado se estão na mesma direção do cenário mundial.

\subsection{Breve histórico do ensino do turismo no Brasil}

Com o fim de analisar os cursos superiores de turismo, será feita primeiramente uma contextualização histórica dos cursos superiores no Brasil e em seguida, dos cursos de bacharelado em turismo. Porém, antes de abordar esta análise, segue uma observação do professor Luiz Trigo, a respeito dos novos rumos da educação em turismo:

\footnotetext{
Temos de ser críticos e não dogmáticos em nossa profissão. Os estudantes e professores precisam ser mais exigentes com seus parâmetros de qualidade educacional e profissional. Temos de entender que o turismo tornou-se um fenômeno social e uma atividade econômica vasta, que envolve profissionais de várias áreas e segmentos econômicos de distintas origens. Se quisermos avançar nesse campo e obter mais reconhecimento precisamos estudar e trabalhar com vontade. (In MATIAS, 2002, p.XV).
}

Iniciando a análise do percurso histórico sobre as universidades no Brasil, notase que há um padrão que foi seguido desde a época do Império trazido pelos costumes portugueses. O modelo de concentração do acesso à universidade acontece desde o século XIX, quando o ensino superior estava presente apenas nos grandes centros. A partir deste período, da mesma forma tem início o ensino profissionalizante, voltado à desenvolver habilidades práticas num modelo de fazer-saber. A colocação a seguir mostra este contexto do período imperial:

Já nos referimos à resistência que o Brasil ofereceu à ideia de universidade. Habituando-se a somente tê-la na Metrópole, ao fazer-se independente viu reduzir-se o ensino superior a escolas especiais profissionais, fora da universidade. (TEIXEIRA, 1989, p. 71)

Esta característica funcional e de aplicabilidade prática que os cursos superiores no Brasil tiveram na sua criação, de certa forma ainda traz consequências aos modelos educacionais correntes. É histórica a colocação da teoria e da investigação científica em segundo plano, dando prioridade à formação pragmática. Não se quer dizer que esta característica seja preponderante no ensino atual, contudo, ainda se apresentam seus efeitos. Esta forma de ensinar também influencia na maneira em que os futuros docentes 
recebem o conhecimento que irão repassar em sua vivência profissional. Ou como diz o seguinte relato:

Como só teve o Brasil, no nível superior, escolas profissionais de saber aplicado, o seu ensino secundário acadêmico de humanidades e ciências teria de ser inevitavelmente precário e deficiente, como sempre foi durante essa longa experiência de ausência da universidade ou das respectivas escolas superiores para licenciar os docentes Não esqueçamos que os graus universitários são licenças de docência. (TEIXEIRA, 1999, p. 71)

Outro traço histórico apresentado na educação superior brasileira é a valorização em excesso dos modelos de outros países em detrimento de nossas diretrizes educacionais. Havia um entendimento de que iniciar os estudos de nível superior em outro país poderia oferecer mais qualidade e do que frequentar as instituições de ensino brasileiras. Referente à este cenário, tem-se a origem também nos tempos de império:

Com efeito, uma elite com uma educação de segunda mão, vaidosa de preferir o latim e, depois, o francês ao próprio português, mas com inequívocos traços de gosto intelectual, permitiu-nos a ilusão de considerar a espantosa estagnação do século XIX, graças à qual se pôde guardar até a escravidão como exemplo de algum modo raro de estabilidade, de sabedoria política e de cordura nacional, comparado com o tumulto político de grande parte da América Latina. (TEIXEIRA, 1989, p. 70)

Ao se estabelecer um elo entre a origem da educação superior no Brasil, e o contexto contemporâneo do ensino superior, compreende-se que a característica de predomínio do pragmatismo, sobre a postura reflexiva está relacionada historicamente, à prioridade que se deu à preparação dos recursos para atender ao chamado do desenvolvimento econômico, que era considerado como o mote propulsor para o progresso do novo país. O interessante é perceber como a educação universitária era vista como algo ultrapassado, sem nunca mesmo ter se desenvolvido no Brasil.

\footnotetext{
Havia no Brasil, na classe governante brasileira, a idéia de que a sociedade que se estava construindo ia ser uma sociedade utilitária, uma sociedade de trabalho e, como tal, não ganharia muito em receber os ornamentos e as riquezas da velha educação universitária. (TEIXEIRA, 1989, p.82)
}

Na trajetória histórica das universidades no Brasil esteve presente também, uma incerteza sobre a formação dos docentes que teriam o papel de transmitir o conhecimento para os estudantes que aparentemente buscavam apenas a formação profissional no sentido estrito do termo. Ao mesmo tempo que estes docentes eram incumbidos de preparar novos profissionais para um mercado em expansão da mesma forma jovem, não recebiam a formação necessária para uma atuação profissional plena e 
que conseguisse passar uma integração dos saberes em sala de aula. Novamente, como um recurso de suporte para o ensino acadêmico, se recorre ao modelo cultural de outros países. Sobre isto:

Criamos nossas escolas superiores puramente profissionais e mantivemos um ensino secundário de tipo clássico e acadêmico. Mas, onde as fontes para o preparo de professores para esses dois tipos de ensino? Com os resíduos da cultura que trazíamos do período colonial, íamos manter tais escolas, mas como iríamos preparar os seus professores? Tivemos que confiar as fontes de nossa cultura ao puro autodidatismo, pela leitura dos livros estrangeiros que as novas condições de difusão da cultura nos viriam trazer e pela possibilidade de viagens à Europa. (TEIXEIRA, 1989, p. 95)

A falta de uma consciência acadêmica e de pesquisa, criou no Brasil, devido a fatores como a assimilação da cultura de ensino estrangeira em prejuízo dos valores e saberes locais, prioridade para o ensino com foco para formação técnica e despreparo do corpo docente em função de um sistema recente de universidade. A estes fatores juntava-se a dificuldade em criar estruturas curriculares coesas e uma sistematização do ensino que abarcasse as necessidades de conhecimento técnico e teórico integrados.

Faltando a formação intelectual acadêmica, pelos estudos sistemáticos desinteressados, não tinha como o brasileiro obter a chamada cultura acadêmica, que lhe daria a verdadeira disciplina intelectual dos estudos avançados em qualquer campo de cultura especializada ou geral. (TEIXEIRA, 1989, p. 95)

Enquanto em outros países se desenvolviam novas visões e posturas a respeito da educação formal e de como esta poderia ter papel decisivo inclusive para a construção de uma identidade nacional, no Brasil o percurso educacional parecia ter como objetivo principal a aplicação utilitária dos conteúdos curriculares.

Saíamos da cultura greco-latina para a cultura vernácula, primeiro; depois para a cultura nacional, e por fim, para a cultura científica, e foi todo esse movimento que o Brasil ignorou, vivendo 114 anos, de 1808 a 1922, sem as instituições destinadas a formular e a ministrar, no nível superior, a cultura nacional e a cultura cientifica pura, ou básica, ou "desinteressada", no sentido de não apenas aplicada. (TEIXEIRA, 1989, p. 97)

Depois deste período de lacuna do ensino de formação superior, as transformações e diga-se que até mesmo as movimentações neste setor educacional iniciam-se após a década de 20. A partir das mudanças ocorridas em decorrência da Primeira Guerra Mundial, acontece no mundo e no Brasil um rápido e crescente processo de modernização. E com a presença maior da ciência e tecnologia no setor produtivo, o sistema de ensino no Brasil foi reformulado. Especificamente no Brasil, a 
Revolução de 1930 que trouxe importantes demandas sociais também colaborou para que houvesse um rompimento com a estabilidade aparentemente benéfica que se mantinha nos padrões educacionais.

\begin{abstract}
A revolução de 1930, que rompe com a situação imobilista anterior abre, afinal, perspectivas para a mudança social, e logo em 1931 promulga-se o Estatuto da Universidade Brasileira com a inovação de permitir que uma escola de letras, ciências e educação pudesse substituir uma das três escolas tradicionais na constituição da universidade. Em 1934 surge a Universidade de São Paulo congregando além das escolas tradicionais, a Faculdade de Filosofia, Ciências e Letras e o Instituto de Educação e, quase ao mesmo tempo, a Universidade do Distrito Federal, com as Escolas de Economia e Direito, de Ciências, de Letras, de Educação e o Instituto de Artes. Em 1937 reorganiza-se a Universidade do Rio de Janeiro, como Universidade do Brasil, com a Faculdade de Filosofia e depois a escola de economia e outras mais. (TEIXEIRA, 1989, p. 105).
\end{abstract}

Somente em 1961 com a votação da Lei de Diretrizes e Bases da Educação Nacional é que aconteceu de fato um movimento no sentido de pensar e rever o papel e posicionamento da universidade, sobretudo em relação às questões sociais. O projeto de Lei de Diretrizes e Bases ficou estagnado durante 15 anos, embora tenha sido proposto em 1946.

\footnotetext{
Restauradas as condições democráticas com a Constituição de 1946, surge, afinal, o projeto da Lei de Diretrizes e Bases da educação nacional, mas o mesmo não logra entrar em discussão na Câmara Federal senão em 1961, sob a forma de um substitutivo em parte discordante do modelo inicial.Durante esse período de expectativa da nova lei, o sistema existente continuou a crescer, multiplicando-se as escolas. A situação real que se estabeleceu foi a de se continuar a criar escolas com o propósito dominante de se credenciarem os educados, melhor diria, os diplomados, para os postos e posições que se reputavam privilegiados para a constituição da elite do país. (TEIXEIRA, 1989, p. 111)
}

Neste intervalo em que houve a espera desta lei, viu-se aumentar de forma rápida o número de instituições de ensino superior. Dado que o número de professores qualificados era em sua maioria de cursos tradicionais como Direito, Medicina e Engenharia, com o objetivo principal de multiplicar a quantidade de instituições e possibilitar que dentro de um sistema de cátedras, os professores conseguissem atender à uma demanda possível de estudantes. Por este motivo, quando se chegava em um limite de estudantes para determinado catedrático, ao invés de um incremento na instituição já existente, a solução era a criação de uma nova instituição que seria atendida por outros catedráticos. Esse sistema de cátedras se unia diretamente aos modelos de currículos únicos e uniformes. Estes modelos de currículo e estruturação 
dos cursos dificultava a mínima interação de conhecimentos correlatos e interferentes entre si. São modelos tradicionais, mas que hoje positivamente são repensados e reestruturados. Mais adiante será relatado o caso específico dos cursos de turismo.

Chegada a certo ponto, a ampliação da matrícula só se podia fazer com a criação de uma nova escola. O numerus clausus, que se veio a adotar, não dependia da escola e seu prédio e instalações, mas do número de catedráticos. (TEIXEIRA, 1989, p. 111)

Esta perspectiva de relação de conhecimento centralizado em alguns professores, estabelecia uma relação de poder hierarquizado sobre os estudantes, visto que o percurso teórico e prático da caminhada acadêmica dependia diretamente da disponibilidade e repasse de conteúdo atrelado à um professor específico. Este contexto onde poucos detinham o conhecimento era obstáculo a uma discussão aberta, flexível e rica em termos de desenvolvimento teórico e científico. Acredita-se que estes moldes tradicionais do ensino superior no Brasil tiveram uma grande contribuição para os entraves que de certa forma ainda se fazem presentes na elaboração de currículos dos cursos de turismo que sejam mais aplicáveis tanto no campo teórico quanto prático e mais próximos da realidade social.

Ainda dentro deste intervalo, no período entre 1937 a 1945, que também coincide com o Estado Novo, continuou sendo priorizada a formação técnica e profissional e a aproximação da escola com o mundo do trabalho. A criação do SENAI e do SENAC implantou um sistema de ensino profissionalizante que formava mão de obra específica para o mercado.

\footnotetext{
A política do Estado Novo caracterizou-se pela centralização autoritária e pela preocupação em aproximar a escola do mundo do trabalho. Essas intenções políticas não se evidenciaram só na legislação do ensino - as leis orgânicas -, mas também na criação do Senai e do Senac e na criação de escolas técnicas nos mais diversos estados. (BARRETO; TAMANINI; DA SILVA, 2004, p.16).
}

No período da ditadura militar, a universidade foi tratada com prioridade devido a necessidade de formação de técnicos universitários para atender os interesses políticoeconômicos da época que visavam uma aceleração do crescimento industrial do país. No que diz respeito ao turismo, este foi um período importante, com a elaboração da Política Nacional de Turismo em 1966 e a criação da Embratur em 1967. (BARRETO; TAMANINI; DA SILVA, 2004, p.53). No entanto, há registros de que a Embratur não foi criada visando apenas a institucionalização do turismo do Brasil internacionalmente. 
De acordo com Santos Filho (2003), a Embratur não foi criada apenas com o intuito de incrementar o turismo no Brasil, mas, também, para desfazer a imagem do país no exterior apresentada pelos exilados e pela imprensa internacional, atribuída, pelos militares, às calúnias dos comunistas. (BARRETO; TAMANINI; DA SILVA, 2004, p. 55).

Em 1968, com a implementação da Reforma Universitária pelo regime militar foram apresentadas mudanças significativas no modelo de ensino superior como o fim do sistema de cátedra, a criação de departamentos, entre outras.

\begin{abstract}
No início da década de 1970, as universidades públicas e confessionais, já se encontravam estruturadas com base nos seguintes padrões acadêmicos: introdução dos vestibulares unificados e classificatórios; fim do sistema de cátedra; dedicação exclusiva dos docentes; criação dos departamentos; adoção do regime de créditos como mecanismo de integralização dos cursos; indissociabilidade entre ensino e pesquisa; cursos de graduação divididos em duas fases: ciclo básico e especialização profissional; e pós-graduação composta de dois cursos distintos: mestrado e doutorado. (FERREIRA JR; BITTAR, 2004).
\end{abstract}

Após este período de crescimento acelerado no ensino superior no Brasil, o país volta a passar por um intervalo de estagnação. Esta paralisação está relacionada à crise econômica da época, mas não somente isto. No Brasil, com a baixa taxa de escolaridade que provinha das décadas anteriores, grande parte da população era analfabeta e ainda havia um alto índice de repetência e evasão do ensino. Este contexto se deve à falta de investimentos na educação pública, seja do nível mais básico ao superior.

O que se observa historicamente é que o ensino técnico, que visa à preparação para o mercado foi deslocado do ensino do segundo grau para o ensino superior. Conforme Barreto, Tamanini e da Silva (2004, p.29):

\footnotetext{
Minimizando o nível de conhecimento e de exigências no primeiro e no segundo graus, forja-se, literalmente, a necessidade de continuar os estudos, aplicando, com isso, à educação as mesmas leis que regem, no capitalismo, o consumo de qualquer bem ou serviço: estimular a compra permanente criando a necessidade de melhoria ou renovação. (...)Forja-se a qualificação "pelo alto", porque as pessoas acreditam que estão tendo ensino universitário quando estão recebendo capacitação técnica. Ao mesmo tempo, dando-se às pessoas o status de "universitários", forja-se a ascensão social.
}

O cenário econômico e social do final da década de 60 favorece um interesse sobre a atividade turística, sendo nesta época a elaboração das primeiras políticas e a criação da primeira instituição pública para a organização e promoção do turismo brasileiro. Na conjuntura econômica, essa época coincide com a "descoberta" do turismo como "indústria" promissora, que levou ao estabelecimento da Política 
Nacional de Turismo em 1966 e à criação da Embratur em 1967. (BARRETO, TAMANINI, DA SILVA, 2004, p.53).

Seguindo o contexto de atender à demanda de mercado, em 1971 tem início o primeiro curso de Turismo na Faculdade Morumbi, atual Universidade Anhembi Morumbi. Em 1975, no I Congresso Nacional de Turismo, o professor Mário Beni faz uma reflexão sobre a importância dos cursos de Turismo.

A partir da instalação do primeiro curso superior de Turismo no Brasil, a fase da improvisação, adaptação e repentinidade começa a ser seriamente ameaçada. $\mathrm{O}$ turismo improvidente, desgovernado começa a ser criticamente analisado. São muitos os que hoje se preocupam com a sua problemática, mantendo-se em permanente atividade de reflexão e vigília. [...]

O turismo no Brasil deixou de ter somente posição política administrativa empresarial e passou a constituir-se também, agora em assunto de ordem técnica e científica, e como tal deve ser encarado. [...] (BENI, 1975, apud MATIAS, 2002, p.4)

O fato do curso de Turismo ser recente e não existir um consenso sobre um currículo padrão fez que no seu início houvesse uma incerteza quanto à sua relevância, resultando em algumas tentativas de incorporá-lo ao curso de Administração.

A primeira investida foi na área profissional, quando o Conselho Federal de Técnicos de Administração, [...] criou o registro específico para os bacharéis em Turismo, sem a reserva de mercado para o Bacharel em Turismo e inserindo uma categoria dentro de outra. A segunda tentativa ocorreu na área de formação, por meio da indicação $n^{\circ} 3 / 81$ [...]. Essa legislação era favorável à reestruturação dos cursos isolados de Turismo, para transformá-los em habilitação do curso de Administração [...]. (MATIAS, 2002, p. 9).

No final da década de 70 teve início uma organização como categoria profissional por parte dos bacharéis em Turismo, quando foi criada a Associação Brasileira de Bacharéis em Turismo. Em função disso, estas duas tentativas foram neutralizadas e ao mesmo tempo os bacharéis em turismo conquistaram maior representatividade para defender seus interesses.

Em 1978, houve uma solicitação da Embratur à Escola de Comunicações e Artes da USP (ECA/USP), que por meio de seu curso de turismo, discutisse o tema do currículo mínimo para os cursos de Turismo. Desta forma, a partir de um seminário com a presença da maioria dos responsáveis pelos cursos existentes, estabeleceu-se

(...) um divisor de águas com duas vertentes educacionais adotadas. A primeira, da ECA-USP, que preconizava uma linha filosófica mais acadêmica, voltada à epistemologia, à pesquisa e ao planejamento do turismo. A outra, liderada pela Anhembi-Morumbi, (...) que orientava o conjunto de disciplinas da estrutura curricular para o mercado. Destas vertentes, nasceram os demais cursos que se seguiram até a década de 80. (ANSARAH, 2002, p. 49; BENI, 2003) 
A criação dos cursos de turismo nas instituições de ensino superior no Brasil teve diferentes motivações para sua implementação, de acordo com a localidade onde estavam sendo criados.

O mencionado curso de Turismo da ECA-USP, o primeiro em universidade pública, iniciou suas atividades em março de 1973. A iniciativa para a criação do curso surgiu a partir do II Congresso Nacional de Propaganda realizado na Câmara Municipal de São Paulo em 1971. Neste evento, o então Ministro da Educação, Jarbas Passarinho, sugeriu a criação do curso de graduação em Turismo na USP. No mesmo ano, o Prof. Mário Carlos Beni foi designado para apresentar o Plano de Trabalho referente à Organização Curricular. Após reuniões com professores de outros departamentos da USP, aconteceu a aprovação do curso pela Congregação da ECA e pelo Conselho Universitário da USP em outubro de 1972. (BENI, 2013. p. 28-30)

No caso do curso de turismo da Universidade do Vale do Itajaí em Balneário Camboriú, que atualmente é um dos mais bem conceituados no país, sua criação foi em 1989 e inicialmente passava a ideia de ter sido por uma demanda social. No entanto, mais uma vez se impunha a prioridade para o setor econômico e de desenvolvimento. Ferri e Buratto (2001), citados por Barreto, Tamanini e da Silva (2004, p. 44) relatam que:

\footnotetext{
O curso de turismo da Universidade do Vale do Itajaí (Univali) surgiu, em 1989, a partir da solicitação do poder público e dos empresários do Balneário Camboriú que previam o desenvolvimento turístico do local. Mas a pergunta é: Esses empresários queriam um curso universitário para formar gerentes ou queriam um curso técnico que formasse mão-de-obra? As notícias veiculadas neste verão na imprensa de Santa Catarina parecem indicar a segunda opção como resposta $[\ldots]$
}

Um exemplo muito positivo, também no estado de Santa Catarina, na cidade de Joinville foi o curso de turismo com ênfase em meio ambiente. O curso foi criado em 1999 e tinha como objetivo a formação de profissionais que pensassem em novas alternativas para o turismo da cidade. (BARRETO; TAMANINI; DA SILVA, 2004, p.78)

Até a década de 90 o número de cursos de turismo no Brasil ainda era pequeno. Mas no final desta década houve um crescimento considerável na oferta dos cursos superiores em turismo. De acordo com dados de pesquisa realizada por Ansarah e Rejowski, no final da década de 90 foram identificados 56 cursos superiores de Turismo no Brasil, representando um crescimento de aproximadamente $121 \%$ em relação à 
década de 1980. (MATIAS, 2002, p.7). Esta proliferação dos cursos colaborou para que a profissão do turismólogo que até pouco tempo não era conhecida, se massificasse.

A partir da abertura do mercado brasileiro ao comércio e aos investimentos internacionais, o turismo tornou-se uma atividade econômica de destaque. Houve um crescimento nos serviços de lazer, turismo, hotelaria, gastronomia e entretenimento. E este crescimento refletiu na área de educação. Como o mercado não tinha mão-de-obra qualificada para atender o aumento da demanda, houve um crescimento rápido nos cursos de Turismo, Hotelaria e áreas afins.

Diante desse quadro ocorreu um crescimento desenfreado de cursos de Turismo, Hotelaria e áreas afins no país, sendo que, em 1999, o número de cursos em funcionamento no país chegava a cerca de 200. A maioria desses cursos não dispunha de professores formados e/ou especializados nessas áreas, comprometendo assim a formação profissional. (MATIAS, 2002, p. 9)

Fazendo um apanhado geral, de acordo com pesquisa realizada por Ansarah (2002, p. 73), o percurso histórico dos cursos de Turismo no Brasil passou por quatro fases bem delimitadas:

a) a primeira, na década de 1970 , é marcada pela criação dos cursos, primeiro o de turismo (1971, na Faculdade Anhembi Morumbi, hoje Universidade Anhembi Morumbi, sediada em SP), e posteriormente os de hotelaria (1978, inicialmente com os cursos tecnológicos iniciados pela Universidade de Caxias do Sul - RS, que fundou o Núcleo Universitário no município de Canela - RS, onde sediou a Escola Superior de Hotelaria, com dois anos de duração, sendo em 1979 reconhecido pelo MEC), ambos com expansão moderada, totalizando dez cursos no final da década e com oferta direcionada às grandes capitais brasileiras como SP e RJ.

b) A segunda fase, na década de 1980, foi marcada pela estagnação de oferta de cursos decorrente de problemas econômicos no País, o que ocasionou inclusive o fechamento de vários cursos;

c) A terceira fase, na década de 1990, caracteriza-se pela valorização dos cursos no âmbito acadêmico, com aumento do número de cursos nas áreas de turismo, hotelaria e administração com habilitação em turismo e hotelaria nas capitais e com distribuição mais igualitárias nas demais regiões brasileiras, abrangendo e estendendo-se ao interior de vários estados;

d) A quarta fase é a atualidade e que deverá estabelecer o equilíbrio "quantidade versus qualidade", com aumento quantitativo de propostas diferenciadas de cursos e uma tendência de cursos de turismo com ênfases direcionadas para a flexibilização e a regionalização, como recomenda a LDB, 1996. Alguns exemplos são eventos, ecoturismo, lazer, recreação, agenciamento, hotelaria e planejamento. Já para os cursos de administração, observa-se habilitação diversificada. Primeiramente uma concentração em turismo com habilitações em gestão de serviços turísticos, gestão em turismo, empreendimentos turísticos. Outra concentração é direcionada à hotelaria, com habilitações voltadas para administração hoteleira, gestão hoteleira, empresas hoteleiras, gestão em hotelaria e restaurantes; e ainda as habilitações para a formação em turismo e hotelaria como: administração em hotelaria e eventos, administração em turismo rural 
e hotelaria, gestão em serviços turísticos e hoteleiros, turismo e hotelaria, gestão em turismo e hotelaria, entre outros. Por fim, outras habilitações como administração em turismo e lazer, hotelaria e lazer, gestão hospitalar e hotelaria.

Partindo do histórico apresentado dos cursos de Turismo no Brasil, observa-se que inicialmente a preocupação central estava em atender a demanda de mercado e formar profissionais preparados operacional e tecnicamente. A preocupação com o equilíbrio entre o conteúdo teórico e a prática é mais recente e tem rendido diversas discussões produtivas e que visam o aumento da qualidade dos cursos do ponto de vista acadêmico e profissional. Com esta pesquisa pretende-se verificar pelos dois lados, o acadêmico e o profissional, se esta busca pela qualidade e equilíbrio entre teoria e prática tem sido fértil.

Para melhor entender a dinâmica entre a academia e o exercício da profissão do turismólogo, no próximo capítulo será abordada a questão interdisciplinar que está presente nos currículos dos cursos de Turismo.

\subsection{A interdisciplinaridade dos currículos}

Transportar o conhecimento teórico e prático do turismo para um programa curricular pensa-se que não seja tarefa simples, considerando as diversas abordagens que a atividade turística pode apresentar. Citando alguns dos enfoques possíveis, os currículos podem transitar entre o lazer, eventos, planejamento, hospitalidade, elaboração de projetos e roteiros, gestão de empresas turísticas. Este caráter múltiplo gerou inicialmente o impasse para se chegar num currículo padrão dos cursos de turismo.

\footnotetext{
Em uma nova área de estudo, em que os limites e o conteúdo não tiveram tempo suficiente de se estabelecer, tem havido uma tendência para que os acadêmicos avancem com suas próprias definições, conceitos e abordagens (AIREY, 1997 apud BUSBY; FIEDEL, 2001, p. 502, tradução nossa).
}

Há por um lado a argumentação de que os cursos de turismo deveriam ter um currículo único, padronizado, para desta forma, ter mais reconhecimento e expressividade no mundo acadêmico. (...) Sem um acordo para um núcleo comum ou corpo de conhecimentos, as oportunidades para o turismo continuar seu desenvolvimento como uma área de estudo sólida e coerente, se tornam limitadas. (AIREY, 1997 apud BUSBY; FIEDEL, 2001. p. 502-503, tradução nossa). 
A Organização Mundial de Turismo também concorda que há uma múltipla gama de atividades no setor do turismo, o que prejudica o alcance de uma visão conjunta.

(...) [que] o turismo apresenta uma grande diversidade $\mathrm{e}$ heterogeneidade de atividades que dificultam o tratamento conjunto (...). Isso também repercute no aspecto formativo. As ações devem ramificar-se de forma a marcar as diferenças entre essas atividades, embora a partir de uma ideia conjunta e coesa do setor. (OMT 1995, p. 46 apud BARRETO, TAMANINI e DA SILVA, 2004, p. 38)

De acordo com o conceito de Mauss (1974 apud BARRETO, TAMANINI e DA SILVA, 2004, p.48), o turismo, fenômeno social total, não somente aceita, mas precisa do concurso de várias ciências para seu estudo e manejo.

Ritchie (1990, p. 123 apud BARRETO, TAMANINI e DA SILVA, 2004. p. 48) defende que se deveria falar em indústrias turísticas, no plural, visto a diversidade de atividades envolvidas no turismo. Este autor há duas décadas já defendia que o ensino genérico de habilidades administrativas não atendiam à complexidade do turismo. Esta complexidade deveria ser refletida nas estruturas curriculares, de maneira que a interdisciplinaridade estaria presente dada a natureza da atividade turística.

No Brasil, de acordo com Matias (2002, p.12-19) foram apresentadas diferentes propostas de currículo mínimo por parte do MEC, EMBRATUR, ABBTUR, ABDETH e Comissão de Currículos e Programas do III ENBETUR. Isto reforça a dificuldade de se elaborar um corpo teórico próprio do curso de Turismo. Os quadros 1.2 a 1.6 mostram estas propostas que foram apresentadas.

Quadro 1.2 Currículo mínimo do MEC

Resolução s/n. de 28 de janeiro de 1971

\author{
a) Matérias \\ Sociologia \\ História do Brasil \\ Geografia do Brasil \\ História da Cultura \\ Estudos Brasileiros \\ Introdução à Administração \\ Noções de Direito \\ Técnica Publicitária \\ Planejamento e Organização do Turismo
}

b) Estágio em entidades oficiais e privadas de Turismo e Hotelaria 
Destaca-se nesta proposta de currículo, o artigo $5^{\circ}$, que trata da matéria de Noções de Direito e diz que incluirá o Direito Constitucional, Direito Fiscal Alfandegário, Da Legislação Trabalhista, Estatuto Jurídico do Estrangeiro e da Legislação específica do Turismo. Neste caso nota-se dentro da mesma disciplina curricular, a interdisciplinaridade presente, visto que além da matéria específica do Turismo, a disciplina também se propõe ao estudo de outras matérias pertinentes ao Direito.

Quadro 1.3 Proposta de currículo mínimo da Comissão de Currículos e Programas do III ENBETUR (1981)

\begin{tabular}{|c|c|c|}
\hline a) Matérias do Currículo & b) Habilitações & c) Objetivo das Habilitações \\
\hline $\begin{array}{l}\text { Sociologia } \\
\text { História } \\
\text { Geografia } \\
\text { Administração } \\
\text { Direito } \\
\text { Ciências e Técnicas da Comunicação } \\
\text { Planejamento e Organização do Turismo } \\
\text { Estatística } \\
\text { Metodologia Científica } \\
\text { Economia } \\
\text { Psicologia } \\
\text { Antropologia } \\
\text { Contabilidade }\end{array}$ & $\begin{array}{l}\text { Administração de Empresas } \\
\text { Turísticas } \\
\text { Planejamento do Turismo } \\
\text { Animação Turística }\end{array}$ & $\begin{array}{l}\text { Planejamento do Turismo - } \\
\text { formar profissionais para atuar em } \\
\text { assessorias e para elaborar o } \\
\text { planejamento da atividade turística e } \\
\text { de lazer em nível de } \\
\text { macroplanejamento de núcleos } \\
\text { receptores emissores urbanos e } \\
\text { rurais. }\end{array}$ \\
\hline & & $\begin{array}{l}\text { Animação Turística - formar } \\
\text { profissionais para atuar nas atividades } \\
\text { de animação ligadas ao lazer, } \\
\text { recreação e turismo, dando ênfase aos } \\
\text { agentes culturais e guias de turismo, } \\
\text { distintos daqueles formados em nível } \\
\text { de } 2^{\circ} \text { grau. }\end{array}$ \\
\hline
\end{tabular}

Nesta proposta apresentada no III ENBETUR, além da interdisciplinaridade das matérias integrantes do currículo, há também o caráter interdisciplinar nas habilitações oferecidas pelo curso, já que cada uma delas é direcionada para uma atuação profissional específica. 
Quadro 1.4 Proposta de currículo mínimo da EMBRATUR (1981)

\begin{tabular}{|c|c|}
\hline a) Matérias Básicas & Habilitações Alternativas \\
\hline $\begin{array}{l}\text { Matemática } \\
\text { Estatística } \\
\text { Teoria Econômica } \\
\text { Metodologia Científica } \\
\text { Planejamento e Organização do Turismo } \\
\text { Legislação Aplicada } \\
\text { Mercadologia } \\
\text { Psicologia }\end{array}$ & $\begin{array}{l}\mathbf{1}^{\mathbf{a}} \text { Opção - Hotelaria } \\
\text { Organização Hoteleira e Técnicas Operacionais } \\
\text { Administração Hoteleira } \\
\text { Administração Financeira e Orçamento } \\
\text { Mercadologia Aplicada } \\
\text { Prática - Estágio } \\
\\
\mathbf{2}^{\mathbf{a}} \text { Opção - Agenciamento e Transporte } \\
\text { Produção e Organização de Serviços Turísticos } \\
\text { Administração Aplicada } \\
\text { Administração Financeira e Orçamento } \\
\text { Mercadologia } \\
\text { Prática - Estágio } \\
\text { 3apção - Planejamento } \\
\text { Sociologia } \\
\text { Organização de Turismo Interno e Externo } \\
\text { Infraestrutura Turística } \\
\text { Equipamento Turístico } \\
\text { Elaboração e Análise de Projetos } \\
\text { Prática - Estágio }\end{array}$ \\
\hline
\end{tabular}

Na proposta apresentada pela EMBRATUR, verifica-se nas matérias básicas, a presença de disciplinas mais direcionadas à questão econômica e de mercado.

Quadro 1.5 Proposta de currículo mínimo da ABBTUR (1995)

\begin{tabular}{|c|c|c|}
\hline $\begin{array}{c}\text { Matérias ou disciplinas } \\
\text { tronco }\end{array}$ & $\begin{array}{c}\text { Matérias ou Disciplinas } \\
\text { Eletivas }\end{array}$ & Ênfases sugeridas \\
\hline $\begin{array}{l}\text { Sociologia } \\
\text { História do Brasil } \\
\text { Geografia do Brasil } \\
\text { História da Cultura } \\
\text { Patrimônio Turístico } \\
\text { Introdução à Administração } \\
\text { Noções de Direito } \\
\text { Técnicas Publicitárias } \\
\text { Planejamento e Organização do } \\
\text { Turismo }\end{array}$ & $\begin{array}{l}\text { Psicologia } \\
\text { Língua Estrangeira } \\
\text { Economia } \\
\text { Realidade Socioeconômica e Política } \\
\text { Regional } \\
\text { Teoria Geral de Sistemas e Métodos } \\
\text { de Pesquisa em Turismo } \\
\text { Filosofia } \\
\text { Língua Portuguesa } \\
\text { Meio Ambiente } \\
\text { Relações Humanas }\end{array}$ & $\begin{array}{l}\text { Agenciamento } \\
\text { Alimentos e Bebidas } \\
\text { Eventos } \\
\text { Hotelaria e Meios de Hospedagem } \\
\text { Lazer e Recreação } \\
\text { Planejamento Turístico } \\
\text { Transportes }\end{array}$ \\
\hline
\end{tabular}


Quadro 1.6 Proposta de currículo mínimo da ABBTUR e ABDETH

\begin{tabular}{|c|c|c|}
\hline $\begin{array}{l}\text { Matérias de Formação } \\
\text { Básica }\end{array}$ & $\begin{array}{l}\text { Matérias de Formação } \\
\text { Profissional }\end{array}$ & $\begin{array}{l}\text { Matérias de Formação } \\
\text { Complementar }\end{array}$ \\
\hline \begin{tabular}{|l|} 
Sociologia \\
Geografia \\
História \\
Administração \\
Direito \\
Economia \\
Estatística \\
Metodologia científica \\
Psicologia
\end{tabular} & $\begin{array}{l}\text { Planejamento e Organização do } \\
\text { Turismo } \\
\text { Teoria Geral do Turismo } \\
\text { Marketing } \\
\text { Eventos } \\
\text { Lazer } \\
\text { Hospedagem } \\
\text { Alimentos e Bebidas } \\
\text { Agenciamento } \\
\text { Transportes } \\
\text { Informática } \\
\text { Contabilidade } \\
\text { Língua Estrangeira }\end{array}$ & $\begin{array}{l}\text { Antropologia } \\
\text { Língua Portuguesa } \\
\text { Matemática }\end{array}$ \\
\hline
\end{tabular}

Esta característica interdisciplinar do turismo demonstrada desde o início dos cursos de bacharelado no Brasil gera uma indefinição sobre qual seria o aspecto central dos currículos.

Na década de 1990, com a finalidade de ajustar os cursos de turismo à formação acadêmica, possibilitar e promover a credibilidade destes, as Diretrizes Curriculares Nacionais elaboradas pelo Ministério de Educação, que tiveram em sua base filosófica as ideias do pensador Edgar Morin, elencaram uma série de competências e habilidades tão ampla e ambiciosa que acaba conflitando com as reais possibilidades de formação, já que praticamente, precisaria haver cursos dentro dos cursos para formar profissionais específicos para uma profissão geral. (BARRETO, TAMANINI e DA SILVA, 2004, p. 74)

O fato do estudo do Turismo abranger disciplinas de diferentes áreas de conhecimento já tornaria difícil o enquadramento de um objeto central de estudo.

Porém, a questão da elaboração curricular passava também pelas disputas acadêmicas entre distintas áreas de formação.

Ao mesmo tempo, dentro da academia há disputas internas pelo turismo como objeto de estudo. Inicialmente a disputa aconteceu na área operacional, entre bacharéis em turismo e professores de educação física, em torno da recreação. Depois entre geógrafos e turismólogos, a partir da organização, por parte dos primeiros, dos Encontros Nacionais de Turismo com Base Local. Notícias que nos chegam da Argentina mostram a disputa entre antropólogos e turismólogos. (BARRETO, TAMANINI e DA SILVA, 2004, p. 47).

Diante da interdisciplinaridade presente no ensino do turismo, talvez haja uma dificuldade em priorizar alguma área do conhecimento em prejuízo de outra. Quem sabe 
a alternativa seja um equilíbrio que tente evitar conhecimentos muito generalizados, superficiais e a especialização em demasia. Moesch $(2002$, p. 28) indica que:

O conhecimento pertinente é aquele capaz de situar qualquer informação em seu contexto e, se possível, no conjunto em que estiver inscrita, contextualizando-a. (...) Quanto mais é desenvolvida a inteligência geral, maior é a sua capacidade de tratar os problemas especiais.

Entre os currículos dos cursos de bacharelado em Turismo que serão analisados nesta pesquisa, nota-se a incidência usual de disciplinas como Geografia Aplicada ao Turismo, Marketing em Turismo, Psicologia Aplicada ao Turismo, dentre outras que são originárias de áreas de conhecimento já existentes e que, aparentemente, tentam se moldar ao ensino do turismo. É como se o conhecimento fosse construído a partir de premissas externas ao objeto central de estudo, que é o turismo.

Eu diria que, de certa forma, é isso que estamos fazendo no ensino e na pesquisa do turismo, quando adaptamos teorias e categorias existentes, conforme o interesse disciplinar de cada área do conhecimento já pré-estabelecidas na academia. Analisamos a Geografia do Turismo, a Economia do Turismo, a Sociologia do Turismo, a Antropologia do Turismo, a Administração do Turismo etc., ao acúmulo de numerosas informações para os alunos ou conhecimentos estanques aos pesquisadores. (MOESCH, 2002, p. 29)

Talvez a criação de categorias originais e peculiares ao turismo seja um caminho a considerar. Ainda de acordo com Moesch (2002, p. 31), avançar na construção de novas categorias para a análise do fenômeno turístico é o objetivo perseguido num processo de investigação interdisciplinar.

Um aspecto que se busca esclarecer é se ao pensar a construção dos currículos dos cursos de turismo, o direcionamento foi para atender ao mercado e à demanda por profissionais qualificados tecnicamente ou se existiu a preocupação pelo estudo do objeto do turismo. Barreto, Tamanini e da Silva (2004, p. 47) ponderam que:

Não há dúvida de que a profissionalização das pessoas que atuam nos diversos setores do turismo melhora o atendimento aos turistas e, consequentemente, o desempenho do turismo no país. O que é, sim, questionável é o fato de o bom desempenho de uma garçonete ou uma comissária de bordo estar mediado por um curso universitário.

A dificuldade que aparentemente se apresenta desde as primeiras propostas de currículo mínimo é de se contextualizar e gerar o conhecimento próprio do turismo a partir do diálogo entre as disciplinas. É possível que esta dificuldade venha das limitações tradicionais da construção do conhecimento que buscam definir e delimitar conceitos sem dialogar com outras áreas. Molina (2000, p. 15), na defesa de um conhecimento que ultrapasse o pensamento linear-cartesiano, diz que: 
La conceptualización de um objeto, processo o fenómeno difiere sustancialmente de la definición que se pueda elaborar de ellos. Mientras definir es delimitar um fenómeno, es decir, señalar brevemente los limites del mismo, conceptualizar implica um esfuerzo de mayor alcance, orientado a compreender y evaluar el sentido de um objeto (por ejemplo, el turismo), el cómo es, el porqué y el para qué del fenómeno.

O conflito entre os interesses do mercado e de uma formação completa para o exercício profissional também podem refletir na elaboração das estruturas curriculares. Se a prioridade do curso é de atender somente à demanda de mercado, é provável que as disciplinas estejam mais direcionadas ao fator econômico e mercadológico. Ao contrário, se a formação é voltada para a plenitude do profissional, é possível que haja um direcionamento mais para questões teóricas. A dificuldade talvez resida justamente em promover o encontro entre mercado e formação acadêmica. Barreto, Tamanini e da Silva (2004, p. 49) questionam: "Dado que nem sempre o que os empresários necessitam é o que a sociedade necessita, qual o papel da universidade?" Formar para um grupo específico da sociedade (os empresários) ou para o conjunto da sociedade mais ampla?

$\mathrm{Na}$ prática, a interdisciplinaridade do turismo trespassa o ensino acadêmico e se reflete na atuação profissional. Beni (2000, p.192-197 apud BARRETO, TAMANINI e DA SILVA) identifica 40 diferentes funções apenas dentro de uma operadora de turismo.

Com o decorrer deste estudo, pretende-se esclarecer como a característica interdisciplinar aparece nos currículos dos cursos de turismo no Brasil e de que forma trabalha as competências profissionais. Neste capítulo o objetivo é descrever a interdisciplinaridade presente nos currículos dos cursos de bacharelado em turismo e não se pretende defender um modelo ideal. A busca que será feita por esta pesquisa é no sentido de responder se há consonância entre o conteúdo curricular e o exercício da profissão. 


\section{MARCOS TEÓRICOS}

Neste capítulo realiza-se a revisão da literatura, apresentando as abordagens a respeito da profissão do turismólogo, das competências e do ensino do turismo. Serão apresentados os conceitos sobre os termos centrais que orientam a pesquisa, como também os principais aportes teóricos que auxiliam na construção da pesquisa.

\subsection{Turismólogo}

O termo turismólogo ainda é relativamente pouco conhecido, sendo que sua aplicação acontece com mais abrangência no ambiente acadêmico e pelos profissionais que tiveram a formação em turismo. Até mesmo na atividade turística, o termo por vezes ainda é desconhecido, sendo frequente a definição do profissional de turismo, pela atividade específica que ele exerce, como agente de viagens, por exemplo. O termo turismólogo define o profissional com formação superior em turismo e que possa exercer o conjunto de ocupações inerentes à atividade turística. O termo turismólogo apareceu no início da década de 70 com o intuito de denominar o profissional que obtivesse a formação acadêmica no curso de turismo, que acabava de surgir no Brasil. ${ }^{1}$

A Associação Brasileira de Turismólogos e Profissionais de Turismo (ABBTUR) diferencia o bacharel em turismo do turismólogo.² Para a ABBTUR,

\footnotetext{
O bacharel em turismo é "um profissional de nível superior egresso dos cursos superiores de turismo e/ou turismo e hotelaria que disseminam ideias, planejam atividades e as gerenciam, através de sua capacidade de análise crítica e reflexiva agindo com responsabilidade técnica e procedimento ético para garantir o desenvolvimento sustentável da atividade nos seus diferentes segmentos, fomentando a pesquisa e o desenvolvimento de novas tecnologias".
}

Também de acordo com a ABBTUR,

O turismólogo é “isento de qualquer pré-requisito de formação acadêmica ou atuação profissional e de registro junto a qualquer órgão federal autárquico, pois é livre o exercício da profissão de turismólogo, em atenção à Lei 12591/12".

Note-se que a ABBTUR inicialmente tinha a denominação de Associação Brasileira de Bachareis de Turismo. A mudança na denominação é recente e consequência da Lei 12591/12. Apesar de a ABBTUR estar em consonância com esta lei e reconhecer a profissão de turismólogo, ao mesmo tempo reforça-se a possibilidade

\footnotetext{
${ }^{1}$ https://pt.wikipedia.org/wiki/Turism\%C3\%B3logo

${ }^{2}$ http://www.abbtur.com.br/abbtur/conteudo.asp?cod=3
} 
de atuação para profissionais de qualquer outra área, visto que não há obrigatoriedade de formação em Turismo para ser considerado turismólogo.

Apenas no ano de 2012 foi criada a lei $n^{\circ} 12.591$, que reconhece a profissão de turismólogo e elenca as atividades que podem ser exercidas por este profissional. De acordo com esta lei, incluem-se entre as atividades de um turismólogo ações de planejamento, gestão e organização de empreendimentos turísticos, criação de roteiros turísticos, pesquisa e informações sobre demanda turística, ensino em nível técnico e superior, entre outras.

Nesta pesquisa adota-se o termo turismólogo com o objetivo de referenciar a todos os profissionais com formação superior em turismo.

\subsection{Competências}

A contextualização sobre competências se faz necessária dado que é a partir deste parâmetro que será realizada a análise da construção do conhecimento necessário para o exercício da profissão do turismólogo. E como a pesquisa relaciona o perfil acadêmico e o exercício profissional, no conceito de competências buscou-se também a relação com a educação e não apenas com a prática.

No cenário da educação, a partir da Lei de Diretrizes e Bases da Educação Nacional, o conceito de competências assume papel relevante.

No contexto das políticas educacionais formuladas a partir da nova LDB, o conceito de competências, embora não seja novo, assume papel central; mesmo apenas anunciado sem se fazer presente nas diretrizes e parâmetros curriculares do ensino fundamental, aparece como categoria central nas diretrizes curriculares para o ensino médio, para a educação profissional e para a formação de professores. (Kuenzer, 2000, p.1)

No contexto do trabalho, a concepção do que é competência passou por duas interpretações dominantes, de acordo com o momento histórico. A primeira ideia de competência aparece na década de 70, ajustada ao modelo de produção fordista, que era predominante. Esta concepção está traz a relação com o saber tácito que entende o conhecimento como a soma de experiências adquiridas.

Determinado por uma modalidade peculiar de divisão social e técnica do trabalho, fundamentada na parcelarização, a competência assume o significado de um saber fazer de natureza psicofísica, antes derivado da experiência do que de atividades intelectuais que articulem conhecimento científico e formas de fazer. Neste sentido, o conceito de competência se aproxima do conceito de saber tácito, síntese de conhecimentos esparsos e práticas laborais vividas ao longo de trajetórias que se diferenciam a partir das diferentes oportunidades e subjetividades dos trabalhadores. Estes saberes não se ensinam e não 
são passíveis de explicação, da mesma forma que não se sistematizam e não identificam suas possíveis relações com o conhecimento teórico. (KUENZER, 2000, p. 1)

$\mathrm{Na}$ nova forma de organização do trabalho, influenciada pelo toyotismo, o conceito de competência está relacionado com o conhecimento científico-tecnológico e sócio-histórico e não mais com as experiências adquiridas. Neste contexto, a escola assume papel fundamental para o desenvolvimento das competências, pois será o meio de aquisição do conhecimento para as classes que não têm acesso à produção cultural, que na época era restrita às elites. Kuenzer (2000, p.2), reforça que:

\begin{abstract}
Embora se saiba que, na classe burguesa estas competências se desenvolvam desde as relações sociais e familiares que viabilizam o desenvolvimento das linguagens, do raciocínio e o acesso à produção cultural, mesmo assim não se prescinde da educação escolar. Já para os que vivem das diferentes formas de trabalho, onde a precarização econômica dificulta o acesso à produção cultural dominante, a escola passa a ser espaço fundamental para a aquisição dos conhecimentos que permitam o desenvolvimento das competências requeridas para a inclusão na vida social e produtiva.
\end{abstract}

O entendimento de competências que é utilizado neste estudo é o que segue a percepção de que um profissional competente não é formado apenas por um conjunto de conhecimentos teóricos e científicos e tampouco se forma somente pela experiência apreendida. A compreensão trazida para esta pesquisa entende que para uma conduta competente é necessária a junção de saberes teóricos e práticos. E que indo além desta ligação destes saberes se faz necessária também a reflexão conjunta sobre eles e a capacidade de estabelecer relações entre estes saberes para a tomada de decisões adequadas nas tarefas da atividade profissional.

A pesquisa que vem sendo realizada permite compreender o conceito
de competência como a capacidade de agir, em situações previstas e
não previstas, com rapidez e eficiência, articulando conhecimentos
tácitos e científicos a experiências de vida laborais e vivenciadas ao
longo das histórias de vida. Ele tem sido vinculado à ideia de
solucionar problemas, mobilizando conhecimentos de forma
transdisciplinar a comportamentos e habilidades psicofísicas, e
transferindo-os para novas situações; supõe, portanto, a capacidade de
atuar mobilizando conhecimentos. (KUENZER, 2000, p. 10)

No conceito que é adotado neste estudo compreende-se também que há uma separação entre o papel do ensino e da prática profissional para o desenvolvimento das competências. Entende-se que a função do ensino é de desenvolver a capacidade cognitiva e de mobilização de conhecimentos para que as competências possam ser desenvolvidas na prática do trabalho. 
A escola é o lugar de aprender a interpretar o mundo para poder transformá-lo, a partir do domínio das categorias de método e de conteúdo que inspirem e que se transformem em práticas de emancipação humana em uma sociedade cada vez mais mediada pelo conhecimento. O lugar de desenvolver competências, que por sua vez mobilizam conhecimentos, mas que com eles não se confundem, é a prática social e produtiva. (KUENZER, 2000, p. 12)

\subsection{Novas tecnologias}

Dentro do estudo de competências para o exercício da profissão do turismólogo, o caráter cultural desempenha papel importante. E na atual cultura de propagação da informação, as tecnologias não podem estar afastadas do processo educacional e da atuação profissional.

A tecnologia desempenha função essencial seja na transmissão dos conhecimentos acadêmicos ou na prática cotidiana do trabalho.

No turismo, a informação e tecnologia são aliadas para a atuação profissional qualificada e conectada com as demandas atuais. A habilidade em utilizar os recursos tecnológicos de forma consciente e responsável, demanda do profissional o senso crítico para filtrar a informação que é válida e benéfica ao exercício de sua atividade.

Desse modo, a informação disponibilizada na Internet passou a ter um valor significativo para o desenvolvimento das atividades do turismólogo, representando o produto final de seu trabalho. Ela tem grande valor, uma vez que está presente em todas as atividades que envolvem pessoas, processos, sistemas, recursos financeiros, planejamento de viagens, entre outros. (DA SILVA; FABRIS, 2007, p.45)

A tecnologia como instrumento da atividade profissional deve auxiliar na etapa inicial, de coleta das informações e no objetivo final que é de repassar estas informações com responsabilidade, auxiliando um grupo social maior. Em da Silva e Fabris (2007, p.51): Existe um imenso potencial epistemológico, emancipatório e social que pode ser vislumbrado através das atividades do turismólogo no contexto da sociedade da informação.

A tecnologia pode ter parcela fundamental para viabilizar o acesso à informação, podendo ser ferramenta de cooperação para o rompimento das estruturas sociais nas quais o conhecimento é usado para dominação e não para a emancipação do sujeito.

Com as transformações revolucionárias que atingem o universo do conhecimento em geral, dotar-se de instrumentos e instituições adequados de gestão nesta área constitui seguramente um eixo essencial de ruptura do nosso atraso. Trata-se de inverter o sinal político das tecnologias, torná-las em instrumento de inclusão, de democratização social através do conhecimento, e não mais instrumento de dominação das elites. (DOWBOR, 2001, p.7). 
O ambiente acadêmico tem papel importante para possibilitar o acesso e a capacitação para a utilização das ferramentas tecnológicas. A capacidade de utilizar os recursos tecnológicos faz parte do conjunto de habilidades e competências necessárias ao desempenho profissional. Trivinõs $(1987$, p. 52) pondera:

(...) forças produtivas: são os meios de produção, os homens, sua experiência de produção, seus hábitos de trabalho. Não obstante, sem considerar a importância única do homem, a força de produção depende fundamentalmente dos instrumentos da tecnologia.

$\mathrm{Na}$ atividade turística a tecnologia desempenha função importante para o exercício da profissão, mas não só como recurso operacional. O profissional também deve estar atento aos novos espaços que são criados e que reproduzem cenários e imaginários para o olhar do turista. Moesch (2002, p. 35) exemplifica:

O que caracteriza esse sistema, baseado na integração multimídia e interconectado de múltiplos modos de COMUNICAÇÃO, é a sua capacidade de incluir e abarcar todas as expressões culturais, onde toda a classe de mensagem funciona de um modo binário: presença/ausência no sistema de COMUNICAÇÃO multimídia. A invariante ESPAÇO permanece no âmago do turismo, mas não como descontinuidade. O novo ESPAÇO de visitação, de testemunho, não incorre em necessidade de translado físico e temporal real.

\subsection{Currículo}

Dado que o propósito deste estudo é relacionar o percurso acadêmico com o exercício da profissão, torna-se necessário abordar alguns tópicos sobre a estruturação dos currículos.

Em geral o termo currículo é utilizado para se referir ao conjunto de disciplinas ou de atividades educacionais presentes em um programa de ensino.

Conforme Rocha (2014, p.1):

Historicamente, o termo currículo foi encontrado em registros do século XVII, sempre relacionado a um projeto de controle do ensino e da aprendizagem, ou seja, da atividade prática da escola. Desde os seus primórdios, currículo envolvia uma associação entre o conceito de ordem e método, caracterizando-se como um instrumento facilitador da administração escolar.

Sob esta concepção o currículo aparece como uma ferramenta facilitadora para a organização sistemática de conteúdos e metodologias. Nesta pesquisa, contudo, se objetiva ultrapassar a noção de currículo como recurso instrumental.

Este estudo se dedica a compreender a natureza sociocultural existente na construção dos programas curriculares dos cursos de bacharelado em Turismo. A 
investigação busca verificar de que maneira o contexto histórico influencia na escolha dos conteúdos para a construção do conhecimento.

A ideia de currículo que será abordada nesta pesquisa, segue a fala de Apple (2006, p.59):

O currículo nunca é apenas um conjunto neutro de conhecimentos [...] Ele é sempre parte de uma tradição seletiva, resultado da seleção de alguém, da visão de algum grupo acerca do que seja conhecimento legítimo. É produto de tensões, conflitos e concessões culturais, políticas e econômicas que organizam e desorganizam um povo.

De acordo com esta concepção, a estrutura curricular poderá sofrer alterações e adaptações de acordo com o momento social, cultural e econômico. A ideologia política e cultural predominante em um período pode ser refletida nos conteúdos selecionados para os programas curriculares, com o objetivo de reproduzir estes valores preponderantes. Nesta perspectiva, Eugênio (2006, p. 51) refere que:

Objetivando superar as análises deterministas da escola, Apple mostra a necessidade de problematizar as formas de currículo encontradas nesta, de maneira que se possa desmascarar seu conteúdo ideológico. Para isso, propõe que três questões sejam investigadas: a quem pertence esse conhecimento? Quem o selecionou? Por que é organizado e transmitido dessa forma?

Neste estudo trabalha-se com esta perspectiva de que o conjunto de conhecimentos inseridos em um modelo curricular passa por influências da lógica sociocultural e econômica que prevalece no momento de sua construção.

Sobretudo, a pesquisa busca trabalhar com o conceito de currículo que procura apreender esta relação entre momento histórico e conhecimento, a partir de uma análise crítica e reflexiva. Desta forma, entende-se que os programas curriculares não são neutros e estão vinculados a valores ideológicos. 


\section{METODOLOGIA}

Este capítulo trata do percurso metodológico que foi utilizado para chegar aos resultados da pesquisa.

A pesquisa utilizou o método dialético histórico-estrutural para a análise referente à formação do turismólogo e de sua atuação profissional. O estudo foi realizado a partir dos cursos de bacharelado criados nos últimos quinze anos. Para esta análise foram pesquisados currículos dos cursos superiores de turismo em instituições de ensino reconhecidas das diferentes regiões do Brasil e também serão apresentadas as diretrizes do Ministério da Educação para o curso superior de Turismo. Para isto se utilizou da pesquisa bibliográfica, de documentos e também de relatos de coordenadores dos cursos estudados.

Para a análise do exercício profissional foram reunidos os relatos de profissionais da atividade turística que tem formação em turismo, além da análise de legislação relacionada à profissão do turismólogo e de concursos realizados para provimento de cargos no setor público de turismo.

Visando auxiliar a construção do marco teórico, partindo dos objetivos propostos anteriormente, a pesquisa foi realizada no nível explicativo que, como menciona Gil (2002, p. 42), tem como preocupação central identificar os fatores que determinam ou que contribuem para a ocorrência dos fenômenos.

Este estudo utilizou também da pesquisa qualitativa, a qual considera relevante a relação entre sujeito e objeto pesquisado e que visa analisar esta relação a partir da subjetividade, que não é possível expressar somente em números.

O emprego da pesquisa qualitativa se explica por permitir uma análise mais ampla e integral do objeto estudado, avaliando os aspectos sociais e históricos que o permeiam. Os antropólogos, que na prática iniciaram o uso da pesquisa qualitativa sentiram a necessidade de um caminho metodológico que ultrapassasse a quantificação e delimitação de dados. Os pesquisadores perceberam rapidamente que muitas informações sobre a vida dos povos não podem ser quantificadas e precisavam ser interpretadas de forma muito mais ampla que circunscrita ao simples dado objetivo. (TRIVIÑOS, 1987, p.120)

Justifica-se também pela importância de se tomar uma posição crítica e reflexiva sobre o objeto de estudo a partir de métodos e técnicas que permitam seu conhecimento aprofundado. 
No contexto da metodologia qualitativa aplicada ao turismo, empregase a concepção trazida das Ciências Humanas, segundo a qual não se busca estudar o fenômeno em si, mas entender seu significado individual ou coletivo para a vida das pessoas. Torna-se indispensável saber o que os fenômenos socioculturais em geral representam para os sujeitos inseridos em contextos específicos. (ALVES, 2011, p. 608).

O intuito da pesquisa é investigar sobre as aptidões necessárias ao exercício da profissão turismólogo para atender às múltiplas interações que estão presentes na atividade turística, que podem ser de caráter empresarial, de serviços, de consultoria ou de ensino, tendo como característica comum a interdisciplinaridade desde os conteúdos para a formação até a atuação profissional. Desta forma, o estudo abordou o cenário geral da atividade turística e de que forma suas características sociais, econômicas e culturais se influenciam. De acordo com Alves (2011, p. 609):

\begin{abstract}
Entretanto, as pesquisas em turismo que adotam a abordagem qualitativa fundamentada na perspectiva dialética e crítica, ainda se encontram em via de construção, tanto no que diz respeito aos pressupostos teóricos quanto aos métodos e técnicas aplicadas. É comum privilegiarem a abordagem funcionalista com enfoque para a dimensão integradora e adaptativa das instituições. Ao se nortearem por funções básicas, como manutenção de padrões, integração e alcance de metas, falam de uma linguagem institucional, que explica muito mais como as instituições se mantêm, do que como se transformam. Ou seja, a atividade econômica como fonte de empregos é o principal foco.
\end{abstract}

Com este estudo pretende-se ultrapassar o relato descritivo e chegar a uma análise que contribua para a reflexão da atividade do turismo e do processo de formação de seus profissionais. Busca-se saber se as diretrizes curriculares estão alinhadas com as solicitações do cenário profissional.

Nos estudos que envolvem o turismo, em alguns momentos se torna difícil optar por uma linha prioritária a ser pesquisada, visto a interdisciplinaridade presente. Há uma controvérsia inicial sobre a atividade turística estar inserida no setor industrial ou de serviços. E há também a diversidade contida na atividade em si, que pode segmentar a atuação profissional para os setores de eventos, hospedagem, transportes, agenciamento, consultoria, planejamento e lazer. Moesch (2002, p. 27) afirma que:

O turismo assim construído na cabeça do estudante é ora uma indústria, ora uma atividade econômica do setor de serviços, ora uma empresa que precisa ser administrada (hotel, agência, eventos) ou um campo para consultores em planejamento, que requereria um perfil de empreendedorismo.

Esta pesquisa investigou independentemente do segmento de atuação, as características sociais, culturais e econômicas da formação em turismo e da atividade 
turística. Visto que um dos objetivos principais é traçar a relação entre a formação e as necessidades profissionais, é fundamental considerar este aspecto interdisciplinar. Isto mais uma vez assinala a preferência pela pesquisa qualitativa como sendo a mais adequada.

No caso das pesquisas qualitativas em turismo, necessário se faz pensar a interdisciplinaridade voltada para o problema teóricometodológico, tanto no que se refere às questões da ciência, propriamente dita, quanto no que diz respeito aos métodos e técnicas relativos a essa abordagem que envolve diversas disciplinas. (ALVES, 2011, p. 611).

\subsection{Instrumentos de Pesquisa}

Para a investigação inicial dos preceitos teóricos e contexto histórico o estudo utilizou-se da pesquisa bibliográfica. Para o desenvolvimento da pesquisa é necessária uma aproximação conceitual e teórica com o conteúdo já abordado sobre o tema pesquisado, por isto, esta etapa preliminar da pesquisa bibliográfica se torna indispensável. A pesquisa bibliográfica é desenvolvida com base em material já elaborado, principalmente de livros e artigos científicos. (GIL, 2002, p. 44).

Em relação aos currículos dos cursos que serão analisados, optou-se pelos cursos de bacharelado que tenham sido criados até o ano de 2000 devido a estarem em atividade há pelo menos quinze anos. A seleção dos cursos para a análise foi feita nas cinco regiões do Brasil, sendo que um dos critérios utilizados foi de selecionar três cursos por região. O Quadro 3.1 lista as instituições selecionadas para a análise dos currículos.

Quadro 3.1 Currículos que serão analisados

\begin{tabular}{|l|l|}
\hline Região & \\
\hline Centro-Oeste & $\begin{array}{l}\text { Instituições } \\
\text { UPIS (DF) } \\
\text { Universidade de Brasília* } \\
\text { Universidade Federal do Mato Grosso do Sul } \\
\text { Universidade de Fortaleza } \\
\text { Universidade Federal do Rio Grande do Norte } \\
\text { Universidade Federal de Pernambuco }\end{array}$ \\
Norte & $\begin{array}{l}\text { Centro Universitário do Norte - Uninorte (AM) } \\
\text { Universidade Federal do Pará } \\
\text { Centro Universitário de Ensino Superior do Amazonas - CIESA } \\
\text { Sudeste } \\
\text { Universidade Anhembi Morumbi (SP) } \\
\text { Universidade Federal Fluminense } \\
\text { Universidade Federal de Juiz de Fora } \\
\text { Universidade Federal de Pelotas } \\
\text { Universidade de Caxias do Sul (RS) } \\
\text { Universidade Estadual do Oeste do Paraná }\end{array}$ \\
\hline
\end{tabular}

\footnotetext{
* O curso de Turismo da Universidade de Brasília não tem quinze anos desde sua criação. Mas considera-se importante o seu estudo, por ser a instituição onde a pesquisadora realiza o seu mestrado.
} 
Outro critério foi o de analisar pelo menos um curso de instituição pública e um curso de instituição privada. A coleta de dados dos cursos foi realizada através do portal e-MEC, vinculado ao Ministério da Educação e nos sítios eletrônicos das instituições.

Além da pesquisa bibliográfica, o estudo também contou com a técnica de questionários. Os questionários têm o objetivo de abranger os dois aspectos que estão sendo relacionados na pesquisa que são a formação e o mundo do trabalho. Logo, a escolha das pessoas a responderem os questionários contemplou a academia e a atuação profissional.

$\mathrm{Na}$ esfera profissional, buscou-se analisar os setores privados e públicos. Para cumprir este objetivo, decidiu-se pela utilização de questionário a profissionais com formação em turismo que atuem em empresas públicas e privadas e em diferentes segmentos, como agências, eventos, operadoras, consultoria e hospitalidade.

A utilização de questionários irá auxiliar na coleta de dados, visto a dificuldade de estar presencialmente em todos os locais de interesse à pesquisa. De acordo com Marconi e Lakatos (2003, p. 201) uma das vantagens de utilizar o questionário é por atingir um grande número de pessoas simultaneamente e abranger uma área geográfica mais ampla.

Com estas técnicas combinadas foi possível obter uma série de informações relevantes que retratam a essência do problema pesquisado e desta forma são de importante contribuição para a análise dos resultados da pesquisa.

\subsection{Método dialético de análise}

A decisão de utilizar o referencial dialético histórico-estrutural vem ao encontro das características da pesquisa qualitativa, que concede espaço à avaliação além do objeto estudado, mas também à análise da relação sujeito e objeto. Como destaca Alves (2011, p. 605):

\footnotetext{
A pesquisa qualitativa tem por princípio as orientações filosóficas da fenomenologia e da dialética, com especificidade no estudo do comportamento humano e social, que se fundamenta na relação dinâmica entre o sujeito e o objeto. Valoriza a contradição do fato observado e a criatividade do pesquisador, cabendo-lhe descobrir o significado das ações e relações sociais.
}

O método dialético permite também maior dinâmica e flexibilidade na análise, dado que não trabalha com teorias imutáveis ou verdades absolutas, entendendo que os 
processos estão sempre em formação e mudança. Assim, considera-se que este método é de relevante contribuição para compreender o processo de formação para a prática profissional, visto que este processo está suscetível às transformações culturais e sociais e, portanto, encontra-se em constante desenvolvimento.

A característica da totalidade que é abordada na pesquisa e que é essencial para a compreensão do método dialético de análise, corrobora a escolha do mesmo, pois esta característica concebe o estudo dos fenômenos em sua integralidade de aspectos.

Portanto, para a dialética, as coisas não são analisadas na qualidade de objetos fixos, mas em movimento: nenhuma coisa está "acabada", encontrando-se sempre em vias de se transformar, desenvolver; o fim de um processo é sempre o começo de outro.

Por outro lado, as coisas não existem isoladas, destacadas uma das outras e independentes, mas como um todo unido, coerente. Tanto a natureza quanto a sociedade são compostas de objetos e fenômenos organicamente ligados entre si, dependendo uns dos outros e, ao mesmo tempo, condicionando-se reciprocamente. (MARCONI; LAKATOS; 2003, p.101)

A escolha deste método de análise permite a investigação de um cenário durante um período determinado e que busca entender de que forma o objeto de estudo recebe influências do contexto social e histórico no qual se insere. Esta característica da historicidade está presente no sentido de buscar a compreensão do objeto de estudo a partir de uma análise de seu trajeto histórico. A historicidade tem ligação direta com as práticas sociais de cada época. Como o estudo propõe-se a pesquisar sobre as competências essenciais para a prática profissional do turismólogo, é preciso que se faça uma investigação que abarque o trajeto histórico do processo de formação profissional do turismólogo e de como este foi influenciado pelo contexto social de cada período. Em sua obra sobre pesquisa em ciências sociais, Triviños $(1987$, p.51) quando aborda o Marxismo, Materialismo Dialético e Histórico, esclarece:

O materialismo histórico é a ciência filosófica do marxismo que estuda as leis sociológicas que caracterizam a vida da sociedade, de sua evolução histórica e da prática social dos homens, no desenvolvimento da humanidade.

A historicidade que se trata aqui não é no sentido de imobilizar os fenômenos estudados em épocas estanques, mas sim de fazer a conexão entre o passado e presente para entender como se deu a evolução do objeto de estudo e suas mudanças ao longo do tempo. Este processo dinâmico, que é influenciado pelas práticas sociais demonstra o caráter de transitoriedade como o método dialético percebe as teorias e a construção do conhecimento. O método dialético tem presente que os processos estão em constante 
transformação e desenvolvimento, sendo que de um movimento anterior pode surgir uma nova ação. De acordo com Netto (2011, p. 46): Por isso mesmo, tanto real quanto teoricamente, as categorias são históricas e transitórias (...).

Reunindo estas características citadas, o método dialético compõe um conjunto de categorias que conferem à análise da pesquisa, o caráter científico imprescindível para que seja ultrapassado o limite do senso comum. O intuito deste trabalho é realizar uma investigação que teve origem em uma percepção pessoal a partir de um contexto social de trabalho vivenciado pela pesquisadora. No entanto, para que a pesquisa não se limite ao campo da percepção pessoal é que se optou por um método de análise que contemple o estudo das interações sociais para além de suas aparências e que busque a investigação da essência dos fatores que influenciam nos fenômenos sociais estudados. A seguinte fala de Triviños (1987, p.51) apresenta uma definição que sintetiza o modo de análise do método dialético.

Por um lado, o materialismo dialético tem uma longa tradição na filosofia materialista e, por outro, que é também antiga concepção na evolução das ideias, baseia-se numa interpretação dialética do mundo. Ambas as raízes do pensar humano se unem para constituir, no materialismo dialético, uma concepção científica da realidade, enriquecida com a prática social da humanidade.

\subsection{Categorias da dialética}

Nesta seção, são apresentadas as categorias de análise da dialética adotadas para a compreensão do estudo.

\subsubsection{Prática}

Partindo do objetivo de estudar a relação entre formação e atuação profissional do turismólogo, é imprescindível o entendimento sobre a categoria da prática.

O estudo de competências necessárias a qualquer atividade profissional perpassa a questão do ensino ou questão teórica e também a execução da atividade em si ou questão prática. Para discorrer sobre o estudo central desta pesquisa que são as competências profissionais do turismólogo, é necessário que se compreenda a relação direta e determinante entre teoria e prática. Como a análise adota o referencial do método dialético histórico-estrutural, é a partir de seus preceitos que se pretende alcançar a compreensão das dimensões teóricas e práticas do objeto de estudo.

Uma das orientações que o método dialético-histórico segue é de que as vivências sociais e culturais são dinâmicas e existem independentemente da vontade ou interferência do sujeito pesquisador. Estas práticas, contudo, seriam o ponto de partida 
para a investigação do objeto. Isto é, o pesquisador é instigado a investigar sobre determinado objeto a partir de uma observação superficial e periférica de um dado acontecimento em seu meio social. Partindo deste questionamento o pesquisador segue para a exploração detalhada e abrangente do objeto na tentativa de acurar o seu olhar e alcançar o máximo de informações possíveis que auxiliem a esclarecer a sua dúvida inicial. Desta forma, o sujeito investigador não traz hipóteses pré-estabelecidas, mas busca uma investigação aprofundada com o objetivo de chegar às respostas possíveis. Após ampla pesquisa do objeto é que o sujeito elabora em seu pensamento a contextualização teórica, ou seja, neste momento é que acontece a reflexão sobre a totalidade do objeto estudado. Assim, a teoria é o movimento real do objeto transposto para o cérebro do pesquisador - é o real reproduzido e interpretado no plano ideal (do pensamento). (NETTO, 2011, p. 21)

Trazendo esta compreensão de teoria e prática para o campo da pesquisa a ser desenvolvida entende-se que a análise inicia a partir de duas situações práticas que são o processo de formação e a atividade profissional. A investigação tem início pela observação e coleta de dados sobre o percurso da formação acadêmica dos turismólogos e sobre seu universo de atuação profissional. Com base no estudo destes dois processos, o educacional e o profissional, planeja-se compreender a interação entre eles. Para atingir esta compreensão, posteriormente à coleta expressiva de informações e ao estudo dos desdobramentos destes fenômenos ao longo do tempo, deve-se seguir uma reflexão crítica da qual podem se originar novos entendimentos ou proposições.

Podemos entender a teoria como um conjunto de conceitos, sistematicamente organizado e que reflete a realidade dos fenômenos materiais sobre a qual foi construída e que serve para descrever, interpretar, explicar e compreender o mundo objetivo. Esse nível de conceitos é o mais alto que pode alcançar o ser humano na explicação e compreensão da vida natural e social. (TRIVIÑOS, 2006, p. 122)

No estudo que será realizado não haverá desvinculação de teoria e prática por entender que as duas caminham juntas, se influenciando mutuamente. A conexão inerente entre teoria e prática está presente na vida humana em geral, mas acredita-se que no processo de formação profissional ela seja essencial.

Nesse processo, o homem age em função de seu conhecimento e conhece para agir, e é na ação que compreende o que é a realidade, configurando-se, assim, ação e conhecimento como dois elementos constitutivos da práxis humana. (OLIVEIRA; ALMEIDA; ARNONI; 2007, p. 35). 


\subsubsection{Totalidade}

Para uma análise relevante das interações e influências entre o processo de formação acadêmica e o desempenho profissional do turismólogo, é necessário que se tenha a compreensão da categoria da totalidade, considerada como central no método dialético.

O processo de formação acadêmica do turismólogo se desenvolve em um percurso situado no âmbito das instituições de ensino, enquanto a prática profissional ocorre no ambiente próprio do mercado de trabalho. Estes dois processos, contudo, têm relação direta e caso sejam estudados de forma desarticulada, podem não refletir a realidade completa do objeto de estudo. A análise fragmentada pode levar a conclusões rasas e apressadas, sem a devida reflexão sobre as múltiplas determinações presentes no objeto estudado.

(...) nunca é demais lembrar e confirmar o estatuto onto-gnosiológico e o valor lógico intrínseco dessa importante categoria, sem a qual qualquer interpretação teórica do mundo fica reduzida a um amontoado incoerente, amorfo e desarticulado de fragmentos, do qual não pode resultar qualquer processo de efetiva produção do conhecimento. (CARVALHO, 2007, p. 179-180)

O método utilizado neste estudo visa realizar uma análise dos processos de formação acadêmica e prática profissional em conjunto. E busca também compreender a dinâmica que move estes processos e que faz com que se influenciem. Carvalho (2007, p. 181) esclarece:

(...) resulta que a desarticulação e a fragmentação desse todo opera uma amputação do mesmo e elimina a possibilidade de conhecê-lo como tal. (...) Em outras palavras, numa totalidade o conhecimento das partes e do todo pressupõe uma reciprocidade, porque o que confere significado tanto ao todo quanto às diversas partes que o formam são determinações, dispostas em relações, que exatamente perpassam e completam a transversalidade do todo, de modo que não pode haver conhecimento de um todo ou de partes dele se, amputada a totalidade (...)

Suspeita-se que um percurso ideal de formação acadêmica apresente esta característica da totalidade no sentido de promover conhecimentos integrados e indo além, que sejam conhecimentos com mobilidade e dinâmica entre si visando a construção de um conjunto de habilidades técnicas, mas também de habilidades humanas para o agir profissional. Mas neste momento, esta é apenas uma suposição, a qual carece de investigação mais aprofundada e isto é o que se propõe a fazer com este estudo. 


\subsubsection{Essência}

O fato de o presente estudo iniciar a observação a partir de uma inquietude profissional da pesquisadora poderia levar ao equívoco de permanecer na concepção empírica do objeto de estudo. Mas como o próprio método dialético tem como um de seus direcionamentos o princípio da contradição, o estudo tentará trazer uma visão consistente e abrangente dos fatores que influenciam nos processos de formação acadêmica e atuação profissional do turismólogo.

O objetivo do pesquisador, indo além da aparência fenomênica, imediata e empírica - por onde necessariamente se inicia o conhecimento, sendo essa aparência um nível da realidade e, portanto, algo importante e não descartável -, é apreender a essência (ou seja: a estrutura e a dinâmica) do objeto. (NETTO, 2011, p.22).

Conectada com as outras categorias, a percepção da essência do objeto estudado inicia na compreensão de que este foi construído historicamente pela prática humana. Para o entendimento deste objeto construído pelo homem é necessário que o sujeito pesquisador transponha a realidade aparente que se exibe a um primeiro olhar, para o nível de sua consciência. A partir desta reflexão sobre o objeto concreto, o pesquisador terá condições de buscar e associar o tanto de conhecimentos e perspectivas que sejam necessários para um entendimento amplo do objeto de estudo. Desta forma, entende-se que o pesquisador inicia a investigação com uma posição passiva, apenas observando o objeto de forma empírica. Contudo, ultrapassando esta observação inicial, o sujeito assume um papel ativo para desvelar o objeto de estudo detalhadamente, considerando o conjunto de aspectos e dinâmicas que o compõem.

\footnotetext{
(...) o papel do sujeito é essencialmente ativo: precisamente para apreender não a aparência ou a forma dada ao objeto, mas a sua essência, a sua estrutura e a sua dinâmica (mais exatamente: para apreendê-lo como um processo), o sujeito deve ser capaz de mobilizar um máximo de conhecimentos, criticá-los, revisá-los e deve ser dotado de criatividade e imaginação. (NETTO, 2011, p.25).
}

Seria incipiente trazer ao estudo apenas uma percepção pessoal gerada empiricamente no trajeto de vivência profissional. A presença de perspectivas diferentes sobre o mesmo tema pesquisado confere maior rigor e genuinidade aos resultados obtidos. Para isto deve ser ultrapassado o cenário das aparências de um olhar inicial. E este comprometimento em analisar o objeto em sua essência, estará presente no desenvolvimento desta pesquisa. 


\section{DESCRIÇÃO E ANÁLISE DOS DADOS}

Neste capítulo serão apresentados os resultados da pesquisa e coleta dos dados. Inicia-se com as Diretrizes Curriculares instituídas pelo Ministério da Educação. Posteriormente, são descritos e analisados os cursos por região e apresentados os resultados dos questionários aplicados junto aos coordenadores dos cursos pesquisados e aos profissionais atuantes na atividade turística. Finalmente, são apresentados os descompassos e convergências entre o conteúdo e a prática do exercício da profissão de turismólogo.

\subsection{Diretrizes do MEC}

As Diretrizes Curriculares Nacionais do Curso de Graduação em Turismo foram instituídas em 24 de novembro de 2006, pela Resolução n ${ }^{\circ} 13$ do Ministério da Educação. No conteúdo destas Diretrizes, há a ressalva para a questão interdisciplinar quando ao tratar do projeto pedagógico do curso, uma das orientações em seu inciso IV do parágrafo $1^{\circ}$ é de que sejam observadas as formas de realização da interdisciplinaridade.

Dentre as competências e habilidades listadas nas Diretrizes Curriculares também se faz presente a característica interdisciplinar. Citando apenas algumas:

Art. $4^{\circ} \mathrm{O}$ curso de graduação em Turismo deve possibilitar a formação profissional que revele, pelo menos, as seguintes competências e habilidades:

VII - planejamento e execução de projetos e programas estratégicos relacionados com empreendimentos turísticos e seu gerenciamento; VIII - intervenção positiva no mercado turístico com sua inserção em espaços novos, emergentes ou inventariados;

IX - classificação, sobre critérios prévios e adequados, de estabelecimentos prestadores de serviços turísticos, incluindo meios de hospedagens, transportadoras, agências de turismo, empresas promotoras de eventos e outras áreas, postas com segurança à disposição do mercado turístico e de sua expansão;

X - domínios de técnicas relacionadas com a seleção e avaliação de informações geográficas, históricas, artísticas, esportivas, recreativas e de entretenimento, folclóricas, artesanais, gastronômicas, religiosas, políticas e outros traços culturais, como diversas formas de manifestação da comunidade humana;

XI - domínio de métodos e técnicas indispensáveis ao estudo dos diferentes mercados turísticos, identificando os prioritários, inclusive para efeito de oferta adequada a cada perfil do turista;

XVII - compreensão da complexidade do mundo globalizado e das sociedades pós-industriais, onde os setores de turismo e entretenimento encontram ambientes propícios para se desenvolverem;

XVIII - profunda vivência e conhecimento das relações humanas, de relações públicas, das articulações interpessoais, com posturas estratégicas do êxito de qualquer evento turístico. 
De acordo com as habilidades listadas anteriormente, para exercer a profissão de turismólogo são necessários conhecimentos de áreas como planejamento, geografia, história, sociologia, relações públicas. Desta forma, sem um olhar aprofundado o curso de turismo pode parecer uma mescla de conhecimentos generalizados de outras profissões. Especificamente em relação ao inciso XVII, que fala da compreensão da complexidade do mundo globalizado e das sociedades pós-industriais, ponderam Barreto, Tamanini e da Silva (2004, p. 74), que esse quesito requer não apenas ser sociólogo, filósofo, cientista político e cientista social, mas ter uma vasta experiência de vida, e isso para tentar entender esse tipo de sociedade.

Visando à adequação dos currículos às realidades locais, em seu artigo $2^{\circ}, \S 2^{\circ}$ as Diretrizes orientam que:

O Projeto Pedagógico do curso de graduação em Turismo poderá admitir Linhas de Formação Específicas, direcionadas para diferentes áreas ocupacionais relacionadas com o turismo, abrangendo os segmentos ecológicos e ambientais, econômicos, culturais, de lazer, de intercâmbio de negócios e promoção de eventos e serviços, para melhor atender as necessidades do perfil profissiográfico que o mercado ou a região exigirem. (BRASIL, Resolução $\mathrm{n}^{\circ} 13$, de 24 de novembro de 2006)

O Ministério de Educação, na elaboração das Diretrizes Curriculares demonstra preocupação em delinear um escopo de conteúdos básicos e específicos que devem ser adotados de maneira geral por todos os cursos de graduação em Turismo. Além disso, expressa a orientação para que sejam inseridos no currículo do curso conteúdos relacionados com a prática da profissão. No artigo $5^{\circ}$ das Diretrizes Curriculares, são expostos os conteúdos que devem constar no Projeto Pedagógico dos cursos.

I - Conteúdos Básicos: estudos relacionados com os aspectos sociológicos, antropológicos, históricos, filosóficos, geográficos, culturais e artísticos, que conformam as sociedades e suas diferentes culturas;

II - Conteúdos Específicos: estudos relacionados com a Teoria Geral do Turismo, Teoria da Informação e da Comunicação, estabelecendo ainda as relações do turismo com a administração, o direito, a economia, a estatística e a contabilidade, além do domínio de, pelo menos, uma língua estrangeira;

III - Conteúdos Teórico-Práticos: estudos localizados nos respectivos espaços de fluxo turístico, compreendendo visitas técnicas, inventário turístico, laboratórios de aprendizagem e de estágios. (BRASIL, Resolução nº 13, de 24 de novembro de 2006)

Na próxima seção será realizada a avaliação dos currículos das Instituições de Ensino Superior selecionadas para a pesquisa, onde será possível verificar como é feito o cumprimento a estas diretrizes instituídas pelo Ministério da Educação. 


\subsection{Descrição dos Cursos por Região}

Visando atingir o objetivo de investigar a relação entre as competências trabalhadas na formação acadêmica e as habilidades requeridas pelo mundo do trabalho serão inicialmente apresentadas nesta seção, as disciplinas obrigatórias e o formato de estágio dos currículos dos cursos de Turismo que foram selecionados para esta pesquisa, das regiões Centro Oeste, Nordeste, Norte, Sul e Sudeste.

É importante destacar que o estudo prioriza as disciplinas obrigatórias com o objetivo de possibilitar a verificação das semelhanças e/ou contrapontos entre os cursos de Turismo contemporâneos.

Os quadros 4.1 a 4.5 apresentam as disciplinas obrigatórias dos currículos referentes ao cursos das Regiões Centro Oeste, Nordeste, Norte, Sul e Sudeste que representam a amostra da pesquisa.

\subsubsection{Região Centro-Oeste}

Entre os cursos avaliados na Região Centro-Oeste apresentadas no Quadro 4.1 (UPIS, Universidade Federal de Mato Grosso e Universidade de Brasília) observa-se um padrão curricular que segue estritamente as orientações das primeiras propostas de currículos mínimos, apresentadas a partir da década de 70 , bem como orientações do MEC nas Diretrizes Curriculares.

Constata-se ainda que há uma oferta reduzida de conteúdos que se apropriem da realidade sociocultural e geográfica da localidade onde se inserem. Há, no entanto, a presença de disciplinas inovadoras como as de Processo Decisório e Criatividade e Turismo Regional e no Distrito Federal e Entorno oferecidas pela UPIS, que é uma instituição privada.

A Universidade de Brasília (UnB), visando a integração entre o conteúdo acadêmico e a prática profissional traz uma inovação relevante com a criação da Empresa Junior Polaris Jr. Esta empresa oferece os serviços de consultoria turística, elaboração de projetos e eventos e é uma forma dos estudantes do curso de graduação em turismo terem o contato com a prática profissional. ${ }^{3}$

\footnotetext{
${ }^{3}$ https://www.facebook.com/polarisjr
} 
Quadro 4.1 - Cursos da Região Centro Oeste

\section{UPIS - Brasília}

\section{$1^{\circ}$ Semestre}

Comunicação Empresarial

Teoria Geral do Turismo

Espanhol Instrumental

Formação Cultural Brasileira

Métodos e Técnicas de Pesquisa

$3^{\circ}$ Semestre

Marketing Turístico

Controladoria e Auditoria, Contabilidade

Gerencial

Organização e Gestão da Recreação, Lazer e

Entretenimento

Tecnologia da Informação

Processo Decisório e Criatividade

Sistemas de Transporte e Agenciamento

$5^{\circ}$ Semestre

Análise Econômica do Turismo

Legislação Turística e Hoteleira

Turismo Cultural e Patrimônio Histórico

Planejamento e Organização do Turismo I

Empreendedorismo no Turismo

\section{$2^{\circ}$ Semestre}

Geografia Aplicada ao Turismo

Políticas Públicas no Turismo

Estatística

Inglês Instrumental

\section{$4^{\circ}$ Semestre}

Planejamento e Gestão de Meios de Hospedagem Recursos Humanos em Turismo e Hospitalidade Desenvolvimento Sustentável e Ecoturismo

Organização e Gestão de Eventos

Turismo Regional e no Distrito Federal e Entorno

\section{$6^{\circ}$ Semestre}

Planejamento e Organização do Turismo II

Gestão de Alimentos e Bebidas

Fotografia de Turismo e Viagens

Turismo Internacional

Estágio Supervisionado (330h)

Trabalho de Conclusão de Curso

\section{Universidade Federal do Mato Grosso do Sul}

\section{$1^{\circ}$ Semestre}

Turismo e Sociedade

Psicologia Social

Agenciamento e Operações Turísticas I

Fundamentos Teóricos do Turismo I

Introdução à Economia

Leitura e Produção de Textos

\section{$3^{\circ}$ Semestre}

Inglês Aplicado à Área do Turismo I Introdução ao Planejamento Estratégico

Geografia do Espaço Mundial

Gestão de Alimentos e Bebidas I

Meios de Hospedagem II

Gestão do Lazer e Entretenimento

Planejamento e Organização de Eventos I

Legislação Turística

Gestão do Turismo

$5^{\circ}$ Semestre

Tópicos Especiais em Turismo I

Estágio Obrigatório em Turismo II (136h)

Cartografia

Empreendedorismo

Gestão da Hotelaria II

Língua Espanhola Instrumental I

Planejamento e Organização do Turismo I

Hospitalidade

Trabalho de Conclusão de Curso I $2^{\circ}$ Semestre

Modalidades e Tipos de Turismo

Estatística

Introdução à Administração

Agenciamento e Operações Turísticas II

História do Brasil

Meios de Hospedagem I

Fundamentos Teóricos do Turismo II

\section{$4^{\circ}$ Semestre}

Estágio Obrigatório em Turismo I (136h)

Gestão da Hotelaria I

Turismo Rural

Planejamento e Organização de Eventos II

Geografia do Brasil

Inglês Aplicado à Área do Turismo II

Gestão de Alimentos e Bebidas II

Métodos e Técnicas de Pesquisa

Contabilidade

\section{$6^{\circ}$ Semestre}

Políticas Públicas em Turismo

Geografia do Turismo

Elaboração de Projetos e Relatórios Técnicos

Marketing Turístico

Geoprocessamento

Língua Espanhola Instrumental II

Tópicos Especiais em Turismo II

Planejamento e Organização do Turismo II

Trabalho de Conclusão de Curso II 
Universidade de Brasília

$1^{\circ}$ Semestre

História: Natureza e Cultura

Estudo do Turismo 1

Sustentabilidade, Ética e Turismo

Inglês Instrumental 1

Geografia e Turismo

Construção do Conhecimento Científico

$3^{\circ}$ Semestre

Estudo do Turismo 3

Estruturas de Suporte ao Turismo

Comunicação no Turismo

Estratégia Empresarial

Cultura Brasileira

$5^{\circ}$ Semestre

Planejamento e Gestão do Turismo 1

Legislação Turística

Estágio Supervisionado 1

$7^{\circ}$ Semestre

Pesquisa em Turismo

Estruturação e Promoção de Destinos $2^{\circ}$ Semestre

Estudo do Turismo 2

Introdução à Economia

Introdução à Administração

Ecologia e Turismo

Projeto Integrador em Turismo 1

\section{$4^{\circ}$ Semestre}

Equipamentos e Serviços Turísticos - Hospedagem Equipamentos e Serviços Turísticos - Lazer

Equipamentos e Serv. Turísticos - Ag. Op. Transp.

Equipamentos e Serviços Turísticos - Eventos

Equipamentos e Serviços Turísticos - Alimentação

Projeto Integrador em Turismo 2

$6^{\circ}$ Semestre

Planejamento e Gestão do Turismo 2

Fundamentos de Estatística Aplicada ao Turismo

Projeto Integrador em Turismo 3

Estágio Supervisionado 2

$8^{\circ}$ Semestre

Projeto Integrador em Turismo 4

Elaboração de Projetos em Turismo

\subsubsection{Região Nordeste}

Quanto aos cursos da região nordeste representados pelas: Universidade de Fortaleza, Universidade do Rio Grande do Norte e Universidade Federal de Pernambuco (Quadro 4.2) acredita-se que característica geográfica e os atrativos naturais possivelmente tenham sido relevantes no momento de elaboração da grade curricular dos cursos.

Nas três instituições pesquisadas aparecem disciplinas voltadas ao meio ambiente e patrimônio natural, mostrando o interesse no estudo conectado com a realidade local e a preocupação com o desenvolvimento ético e sustentável da atividade turística.

\section{Quadro 4.2 - Cursos da Região Nordeste}

\begin{tabular}{|ll|}
\hline & Universidade de Fortaleza \\
\hline $\mathbf{1}^{\mathbf{0}}$ Semestre & $\mathbf{2}^{\mathbf{0}}$ Semestre \\
& \\
Antropologia Filosófica & História e Turismo II \\
Estatística & Metodologia e Técnica de Pesquisa em Turismo \\
História e Turismo I & Patrimônio Cultural e Museologia \\
Língua Portuguesa I & Sociologia do Lazer \\
\hline
\end{tabular}




\begin{tabular}{|l}
\hline Psicologia Aplicada ao Turismo \\
$\mathbf{3}^{\mathbf{0}}$ Semestre \\
Ética e Legislação do Turismo \\
Fundamentos Geográficos do Turismo \\
Matemática Financeira \\
Sistema Turístico \\
Turismo e Cultura Popular \\
$\mathbf{5}^{\mathbf{0}}$ Semestre \\
Gestão Hoteleira \\
Marketing em Turismo \\
Planejamento e Organização do Turismo \\
$\mathbf{7}^{\mathbf{0}}$ Semestre \\
Administração de Eventos \\
Planejamento e Gestão do Lazer \\
Projeto Experimental
\end{tabular}

\author{
Teoria Geral do Turismo \\ $4^{\circ}$ Semestre \\ Administração Contábil e Financeira \\ Gestão de Empresas \\ Meio Ambiente e Patrimônio Natural \\ Teoria Econômica do Turismo
}

\title{
$6^{\circ}$ Semestre
}

Agência Turismo e Transportes

Gestão Ambiental

Planejamento Territorial

\section{$8^{\circ}$ Semestre}

Estágio Supervisionado em Turismo Monografia em Turismo

\section{Universidade Federal do Rio Grande do Norte}

\section{$1^{\circ}$ Semestre}

Formação Histórica do Rio Grande do Norte Administração Contemporânea

Turismo: Organização e Dinâmica

Metodologia da Pesquisa Aplicada ao Turismo

Economia de Serviços

Inglês para fins Acadêmicos I

\section{$3^{\circ}$ Semestre}

Antropologia I

Sociedade, Estado e Política do Turismo

Estatística Aplicada ao Turismo

Língua Espanhola I

Psicologia Aplicada ao Turismo

$5^{\circ}$ Semestre

Recursos Humanos em Turismo

Planejamento Turístico

Marketing Turístico

Sistemas de Informação em Turismo

Sistemas de Transportes

\section{$7^{\circ}$ Semestre}

Elaboração e Avaliação de Projetos

Estágio II (225h)

Monografia I

\section{$2^{\circ}$ Semestre}

Elementos do Patrimônio Histórico Artístico e Cultural Brasileiro Geografia e Turismo

Noções de Direito e Legislação Turística

Análise Estrutural do Turismo

Inglês para fins Acadêmicos II

\section{$4^{\circ}$ Semestre}

Fundamentos de Contabilidade dos Empreendimentos Turísticos Lazer, Animação e Desenvolvimento Humano

Geografia, Turismo e Desenvolvimento Regional

Gestão de Empreendimentos Turísticos

Língua Espanhola II

\section{$6^{\circ}$ Semestre}

Dinâmicas Recreativas de Grupos e Espaços

Planejamento Turístico II

Estágio I (90h)

\section{$8^{\circ}$ Semestre}

Gestão da Qualidade dos Serviços Turísticos

Monografia II

\section{Universidade Federal de Pernambuco}

\section{$1^{\circ}$ Semestre}

Inglês Instrumental Aplicado ao Turismo e à

Hotelaria

Introdução à Administração

Introdução à Filosofia

Metodologia do Trabalho Científico

Patrimônio Histórico e os Bens Materiais e

Imateriais em Pernambuco e no Brasil

Teoria Geral do Turismo 1

$3^{\circ}$ Semestre

Economia do Turismo

Fundamentos de Antropologia

Fundamentos de Marketing

Turismo e Lazer

\section{$2^{\circ}$ Semestre}

Administração Hoteleira

Análise Espacial do Turismo

Comportamento Organizacional

Sociologia do Turismo

Teoria Geral do Turismo 2

\section{$4^{\circ}$ Semestre}

Agenciamento Turístico

Estatística Aplicada ao Turismo e Hotelaria

Legislação Aplicada ao Turismo e à Hotelaria Marketing de Serviços 


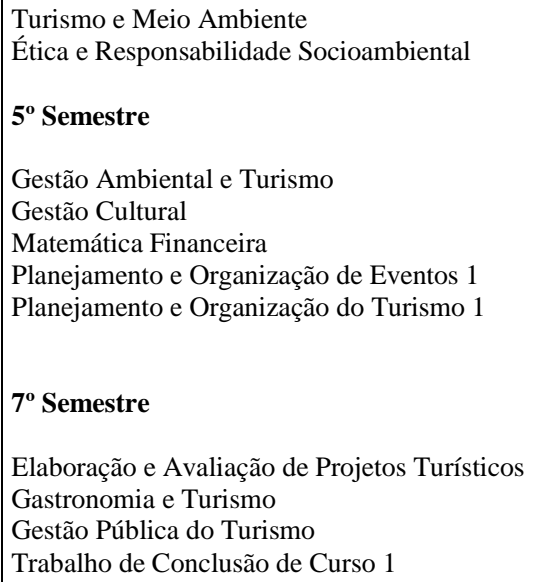

Planejamento e Organização do Lazer

\section{$6^{\circ}$ Semestre}

Contabilidade Aplicada às Empresas Turísticas e Hoteleira Estágio Curricular (300h)

Gestão de Pessoas nas Empresas Turísticas e Hoteleira

Metodologia da Pesquisa Aplicada ao Turismo

Planejamento e Organização de Eventos 2

Planejamento e Organização do Turismo 2

$8^{\circ}$ Semestre

Empreendedorismo

Seminários de Atualização em Turismo e Hotelaria

Sistemas de Informação Aplicados ao Turismo e Hotelaria

Trabalho de Conclusão de Curso 2

\subsubsection{Região Norte}

Na região norte, representada pelo Centro Universitário do Norte, Universidade Federal do Pará e Centro Universitário de Ensino Superior do Amazonas (quadro 4.3), observou-se que além da presença de disciplinas com foco em meio ambiente e natureza, chama a atenção em especial a disciplina de Princípios de Alojamentos de Floresta. Assim como na região nordeste, também expõe a atenção às demandas e questões locais.

Quadro 4.3 - Cursos da Região Norte

\section{Centro Universitário do Norte - UNINORTE}

10 Semestre
Comunicação e Lógica
Introdução à Administração
Introdução à Economia
Teoria Geral do Turismo
Ciência e Sociedade
$\mathbf{3}^{\mathbf{o}}$ Semestre
História da Cultura e da Arte
Marketing Turístico
Produtos, Serviços e Gestão das Agências
de Viagens
Sistema de Transportes
Gestão de Negócios do Turismo
5o Semestre
Políticas Públicas e Planejamento Turístico
Princípios de Alojamentos de Floresta
Tópicos Especiais Integradores
Estágio Supervisionado (240h)
Fundamentos de Alimentos e Bebidas

\section{$2^{\circ}$ Semestre}

Estatística

Fundamentos de História da Amazônia

Planejamento e Organização de Eventos

Sistema Turístico

Contabilidade Básica

$4^{\circ}$ Semestre

Lazer e Entretenimento

Língua Estrangeira - Inglês Básico

Noções de Direito e Legislação Turística

Segmentos do Turismo na Natureza

Fundamentos de Geografia do Turismo e da Amazônia

Meios de Hospedagem Urbanos

$6^{\circ}$ Semestre

Inventário Turístico

Patrimônio Turístico Cultural

Psicologia e Ética nas Organizações Turísticas 
Universidade Federal do Pará

\section{$1^{\circ}$ Semestre}

Inglês I

Teoria Geral do Turismo I

Sociologia do Lazer

Filosofia e Ética Aplicada ao Turismo

Cultura Brasileira

Geografia do Turismo

Administração Geral

$3^{\circ}$ Semestre

Inglês Instrumental

Metodologia de Pesquisa Aplicada ao Turismo

Ecologia da Amazônia Aplicada ao Turismo

História da Amazônia Aplicada ao Turismo

Patrimônio Turístico Cultural

Economia do Turismo

Psicologia Social Aplicada ao Turismo

\section{$5^{\circ}$ Semestre}

Planejamento do Espaço Turístico

Projetos Turísticos

Técnicas de Agenciamento

Lazer e Recreação

Informática Aplicada ao Turismo

Planejamento e Organização de Eventos II

Tópicos Especiais em Turismo

\section{$7^{\circ}$ Semestre}

Análise Econômica e Financeira de Projetos

Turísticos

Marketing Turístico

Gestão de Alimentos e Bebidas

Estágio I (153h)

TCC I

\section{$2^{\circ}$ Semestre}

Inglês II

Teoria do Ecoturismo

Teoria Geral do Turismo II

Estatística Aplicada ao Turismo

Antropologia do Turismo

Cartografia Aplicada ao Turismo

História da Arte Brasileira

\section{$4^{\circ}$ Semestre}

Teoria do Planejamento Turístico

Políticas Públicas e Turismo

Hospitalidade e Turismo

Planejamento e Organização de Eventos I

Transporte e Turismo

Legislação do Turismo

\section{$6^{0}$ Semestre}

Projetos de Empreendimentos Ecoturísticos

Legislação Ambiental e Ecoturismo

Planejamento e Gestão do Ecoturismo

Estrutura e Manejo de Unidades de Conservação para o Ecoturismo

Análise de Impacto Socioambiental para o Ecoturismo

Gestão de Empresas Especializadas em Ecoturismo

\section{$8^{\circ}$ Semestre}

TCC II

Estágio II (153h)

\section{Centro Universitário de Ensino Superior do Amazonas - CIESA}

$1^{\circ}$ Ano

Direito Empresarial

Economia Empresarial

Evolução das Ideias Sociais

Leitura e Produção de Texto

Língua Estrangeira I

Metodologia da Pesquisa Científica

Psicologia Empresarial

Teoria Geral do Turismo

Filosofia de Paradigmas e Ética

$3^{\circ}$ Ano

Agências de Viagem e Transporte

Atividades Complementares

Estudos de Viabilidade de Projetos Turísticos

Gestão de Pessoas para o Turismo

Língua Estrangeira III

Marketing

Orientação de Estágio Supervisionado (222h)

Planejamento e Organização de Eventos

Planejamento e Organização de Turismo

Planejamento Estratégico $2^{\circ}$ Ano

Contabilidade e Análise de Balanço

Estatística

Fundamentos e Teorias da Administração

Gastronomia

Geografia do Turismo

Língua Estrangeira II

Meios de Hospedagem

Patrimônio Histórico e Cultural

Tecnologia e Sistemas

Turismo e Meio Ambiente 


\subsubsection{Região Sudeste}

Na região sudeste, Quadro 4.4 encontra-se o primeiro curso de bacharelado em Turismo criado em 1971, da Universidade Anhembi Morumbi. Uma característica importante entre os currículos desta região é a presença regular de conteúdos voltados à gestão e empreendedorismo, uma vez que permite ao aluno uma aproximação maior com o mundo do trabalho.

Nessa região é importante destacar o diferencial do currículo da Universidade Federal de Juiz de Fora, em que inicialmente, o aluno cursa um Bacharelado Interdisciplinar em Humanidades, e só após esta etapa opta pelo currículo profissional do curso. No nosso entendimento esse passo é relevante na vida acadêmica e profissional do aluno, uma vez que promove uma maior maturidade em sua opção futura.

Quadro 4.4 - Cursos da Região Sudeste

\begin{tabular}{|c|c|}
\hline \multicolumn{2}{|c|}{ Universidade Anhembi Morumbi } \\
\hline $1^{\circ}$ Semestre & $2^{\circ}$ Semestre \\
\hline Comunicação e Expressão & Geografia e Cartografia \\
\hline História e Patrimônio & Gestão de Agências, Viagens e Transportes \\
\hline Hospitalidade & Inglês Aplicado \\
\hline Inglês Operacional & Metodologia Ciência e Normas Técnicas \\
\hline Projeto Integrado I: Turismo & Operações de Meios de Hospedagem \\
\hline Sociologia do Lazer & Organização de Eventos \\
\hline Teoria Geral do Turismo & Projeto Integrado II: Turismo \\
\hline $3^{\circ}$ Semestre & $4^{\circ}$ Semestre \\
\hline Antropologia e Cultura Brasileira & Contabilidade \\
\hline Estatística & Empreendedorismo e Sustentabilidade \\
\hline Gestão de Riscos no Turismo & Operações de Alimentos e Bebidas \\
\hline Marketing em Turismo & Planejamento e Organização do Turismo II \\
\hline Planejamento e Organização do Turismo & Projeto Integrado IV: Turismo \\
\hline Políticas Públicas no Turismo & Turismo Receptivo \\
\hline \\
\hline & Sustentabilidade no Turismo \\
\hline $5^{\circ}$ Semestre & $6^{\circ}$ Semestre \\
\hline Desenvolvimento Humano e Social & Estágio Supervisionado: Turismo \\
\hline Geopolítica e Economia & Finanças Empresariais \\
\hline Marketing Aplicado & Gestão de Recursos Humanos no Turismo \\
\hline Projeto de Conclusão de Curso I & Lazer e Turismo Cultural \\
\hline Projeto Integrado V: Turismo & Projeto de Conclusão de Curso II \\
\hline Turismo Criativo & Projeto Integrado VI: Turismo \\
\hline \multicolumn{2}{|c|}{ Universidade Federal Fluminense } \\
\hline $1^{\circ}$ Semestre & $2^{\circ}$ Semestre \\
\hline Geografia e Espaco Turístico I & Cartografia Aplicada \\
\hline Introdução à Administração & Contabilidade Geral \\
\hline Fundamentos Teóricos do Turismo I & Fundamentos Teóricos do Turismo II \\
\hline Turismo e Desenvolvimento Cultural I & Turismo e Desenvolvimento Cultural II \\
\hline
\end{tabular}




\begin{tabular}{|c|c|}
\hline Turismo e Apreciação Estética I & Lazer e Entretenimento I \\
\hline Microeconomia do Turismo & Sistemas de Informação no Turismo \\
\hline Metodologia da Pesquisa Científica & Macroeconomia do Turismo \\
\hline Estudos Antropológicos do Turismo & Gestão Financeira Aplicada ao Turismo I \\
\hline Ética no Turismo & Espaço Turístico Brasileiro \\
\hline $3^{\circ}$ Semestre & $4^{\circ}$ Semestre \\
\hline Estatística Aplicada ao Turismo & Agenciamento e Operação do Turismo II \\
\hline Planejamento e Organização de Eventos I & Gestão de Meios de Hospedagem \\
\hline Agenciamento e Operação do Turismo I & e Patrimônio Cultural \\
\hline Turismo e Transportes I & Planejamento e Organização de Eventos \\
\hline Hospitalidade & Técnicas de Pesquisas Aplicadas ao Turi \\
\hline Lazer e Entretenimento II & Turismo e Transporte II \\
\hline Turismo e Meio Ambiente & \\
\hline Modelos de Gestão & \\
\hline Gestão Financeira Aplicada ao Turismo II & \\
\hline $5^{\circ}$ Semestre & $6^{\circ}$ Semestre \\
\hline Inglês I & Inglês II \\
\hline Espanhol I & Espanhol II \\
\hline Legislação do Turismo & Gestão de Empresas Turísticas \\
\hline Gestão de Destinos Turísticos I & Marketing Turístico II \\
\hline Marketing Turístico I & Elaboração de Projeto de Pesquisa \\
\hline Est. de Viab. Econ. - Fin. Para Empreend. Tur. & Gestão de Destinos Turísticos II \\
\hline $7^{\circ}$ Semestre & $8^{\circ}$ Semestre \\
\hline Gestão de Pessoas & Trabalho de Conclusão de Curso \\
\hline Gestão da Qualidade Aplicada ao Turismo & Elaboração de Relat. Tec. e Científicos \\
\hline Empreendedorismo I & Tópicos Especiais em Turismo \\
\hline Políticas Públicas de Turismo I & Estágio Supervisionado \\
\hline
\end{tabular}

\section{Universidade Federal de Juiz de Fora - UFJF}

$1^{\circ}$ Ciclo ( $2^{\circ}$ ao $4^{\circ}$ períodos $)$

Mobilidades Contemporâneas

Dimensões da Hospitalidade

Fundamentos do Lazer

Fundamentos do Turismo

Turismo e Globalização

$1^{\circ}$ Ciclo ( $5^{\circ}$ Período - Área de Concentração)

Abordagens Teóricas do Turismo

Organizações e Produção de Bens Turísticos

Fundamentos do Planejamento Turístico

Práticas e Representações Culturais no Turismo Ambiente e Sociedade

$2^{\circ}$ Ciclo ou Profissionalizante

Políticas Públicas em Turismo

Turismo, Consumo e Comunicação

Gestão de Projetos em Turismo

Desenvolvimento e Turismo

Gestão Pública e Social no Turismo

Gestão de Destinos Turísticos

Ênfase 1: Gestão de Empreendimentos Turísticos

$2^{\circ}$ Período

Marketing

Gestão Pública e Social no Turismo

Administração de Recursos Humanos II

Gestão Econômica do Turismo

\section{$4^{\circ}$ Período}

Eventos

Agenciamento e Elaboração de Roteiros

Trabalho Interdisciplinar em Turismo

Meios de Hospedagem

TCC $3^{\circ}$ Período

Administração Financeira Aplicada ao Turismo Logística em Serviços Turísticos e Transportes Alimentos e Bebidas

Projeto do Trabalho de Conclusão de Curso 


\begin{tabular}{|c|c|}
\hline \multicolumn{2}{|c|}{ Ênfase 2: Patrimônio e Gestão de Destinos Turísticos } \\
\hline $2^{\circ}$ Período & $3^{\circ}$ Período \\
\hline Marketing de Destinos Turísticos & Patrimônios Culturais e Turismo \\
\hline Gestão Pública e Social no Turismo & Tópicos Avançados do Turismo \\
\hline Desenvolvimento Local e Sustentabilidade & Gestão de Atrativos Naturais \\
\hline Turismo e Abordagens Geográficas & Projeto do Trabalho de Conclusão de Curso \\
\hline \multicolumn{2}{|l|}{$4^{0}$ Período } \\
\hline \multicolumn{2}{|l|}{ Gestão de Atrativos Culturais } \\
\hline \multicolumn{2}{|l|}{ Turismo e Ruralidades } \\
\hline \multicolumn{2}{|l|}{ Trabalho Interdisciplinar e Turismo } \\
\hline Redes, Atores e Turismo & \\
\hline TCC & \\
\hline
\end{tabular}

\subsubsection{Região Sul}

Nos currículos da região sul apresentados no Quadro 4.5, destaca-se a única ocorrência entre os cursos estudados, das disciplinas Turismo de Base Comunitária e Relações Internacionais Aplicadas ao Turismo. As duas disciplinas são ofertadas na Universidade Estadual do Oeste do Paraná e parecem estar conectadas com a realidade local e global.

Quadro 4.5 - Cursos da Região Sul

\section{Universidade de Caxias do Sul}

$\mathbf{1}^{\mathbf{0}}$ Semestre
Língua Portuguesa Instrumental
Introdução ao Turismo
Inglês I
Espanhol I
Introdução à Computação
História Geral
História do Brasil
$\mathbf{3}^{\text {o Semestre }}$
História da Cultura
Introdução à Administração
Turismo e Meio Ambiente
Inglês III
Espanhol III
Planejamento e Organização do Turismo I
5o Semestre
Iniciação à Pesquisa - CSA
Planejamento e Organização do Turismo III
Administração de Empresas Turísticas
Psicologia do Turismo
Estágio I em Turismo (70 créditos)

\section{$2^{\circ}$ Semestre}

Sociologia

Inglês II

Espanhol II

Economia Aplicada ao Turismo

Geografia Aplicada ao Turismo

Realidade Brasileira

\section{$4^{\circ}$ Semestre}

Cultura e Turismo

Planejamento e Organização do Turismo II

Língua Inglesa IV

Espanhol IV

Teoria da Ciência - CSA

Estatística

\section{$6^{\circ}$ Semestre}

Planejamento e Organização do Turismo IV

Noções de Direito

Planejamento e Organização de Eventos

Técnicas de Publicidade

Marketing Turístico

Estágio II em Turismo (80 créditos) 
Universidade Estadual do Oeste do Paraná

\section{$1^{\circ}$ Ano}

Introdução a Administração

Antropologia

Comunicação e Expressão

Geografia Aplicada ao Turismo

História do Brasil

Hospitalidade

Lazer e Recreação

Legislação ao Turismo

Metodologia da Pesquisa

Teoria Geral do Turismo

\section{$3^{\circ}$ Ano}

Estágio Supervisionado em Turismo

Gestão de Base de Dados no Turismo

Gestão de Eventos

Língua Estrangeira

Logística Aplicada ao Turismo

Marketing Turístico

Meios de Hospedagem

Operações de Viagens

Patrimônio, Identidade e Representações Culturais

Turismo de Base Comunitária

Políticas Públicas do Turismo

\section{$2^{\circ}$ Ano}

Economia do Turismo

Filosofia

Fundamentos de Contabilidade e Finanças

Gestão de Destinos Turísticos

Gestão de Pessoas

Língua Estrangeira

Marketing Turístico

Sociologia do Turismo

Teoria Geral do Turismo

Território e Sociedade

\section{$4^{\circ}$ Ano}

Gerenciamento de Projetos e Consultoria em Turismo Gestão da Gastronomia

Gestão da Qualidade em Produtos e Destinos Turísticos Gestão do Turismo em Áreas Urbanas

Relações Internacionais Aplicadas ao Turismo

Turismo em Áreas Naturais

Tecnologia da Informação e Comunicação em Turismo

Turismo e Educação

Trabalho de Conclusão de Curso

\section{Universidade Federal de Pelotas}

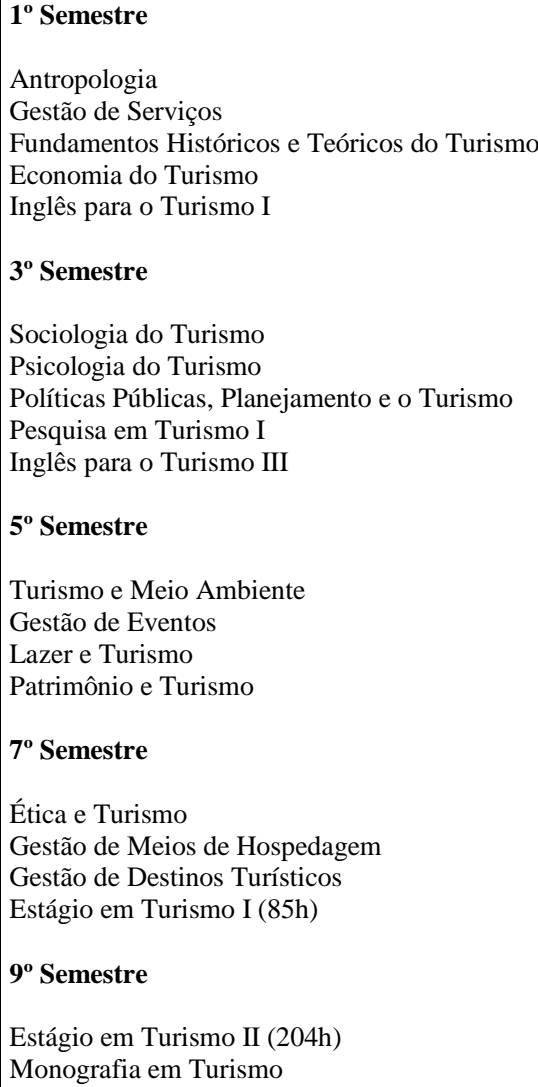

\section{$2^{\circ}$ Semestre}

\section{Gastronomia}

Geografia do Turismo

Turismo Contemporâneo

História do Brasil e do Turismo

Inglês para o Turismo II

\section{$4^{\circ}$ Semestre}

Estatística Descritiva

Gestão de Pessoas

Marketing Turístico

História da Cultura Brasileira e o Turismo

Inglês para o Turismo IV

\section{$6^{\circ}$ Semestre}

Comunicação e Turismo

Gestão de Agências de Viagens e Transportes Turísticos Hospitalidade e Turismo

Legislação Turística

\section{$8^{\circ}$ Semestre}

Pesquisa em Turismo Il

Projetos Turísticos

Adm. Financeira e Orçamentária no Turismo 


\subsection{Análise dos Currículos}

A partir da avaliação dos currículos apresentados observa-se que seguindo as primeiras propostas de currículos mínimos e diretrizes do MEC, há a recorrência de disciplinas fundamentais como Geografia, História, Legislação Turística, Agenciamento, Transportes, Marketing, Economia e Eventos. Estas disciplinas que apresentam apenas diferenças na denominação e que estão presentes na totalidade dos currículos pesquisados possuem relação direta com a atividade do turismo. Portanto não é surpresa a ocorrência delas nos currículos.

Verifica-se ainda que, com exceção de agenciamento, transportes e eventos, as outras disciplinas deste grupo estão ligadas à outras áreas de conhecimento, quais sejam, Geografia, História, Direito, Economia e Marketing. Há disciplinas que não ocorrem em todos os currículos, mas que têm uma frequência considerável e que também estão vinculadas às áreas de conhecimento diversas, como a Psicologia, Sociologia e Antropologia. Isto mais uma vez reforça a característica interdisciplinar dos cursos de Turismo.

Em relação à área pública, das quinze instituições analisadas, dez delas apresentam no currículo disciplinas voltadas a políticas públicas, sendo que destas, apenas três são instituições privadas: UPIS, Universidade Anhembi Morumbi e Centro Universitário do Norte (UNINORTE). Neste ponto reforça-se que as orientações passadas pelas Diretrizes Curriculares do MEC, no seu artigo $4^{\circ}$, parágrafo I que destaca a compreensão das políticas nacionais e regionais sobre turismo é parte das habilidades e competências esperadas de um bacharel em turismo.

A área de planejamento, na qual é possível realizar trabalho de consultoria e ultrapassar o viés comercial da atividade turística é abrangida por todas as instituições estudadas.

Entre os diferenciais encontrados no estudo dos currículos, aparecem instituições que demonstram o empenho em ajustar a grade curricular ao contexto local e regional onde se situa. No centro oeste é o caso da UPIS, com a disciplina de Turismo Regional e no Distrito Federal e Entorno. No nordeste, a UFRN apresenta a disciplina de Formação Histórica do Rio Grande do Norte, enquanto a UFPE traz a disciplina Patrimônio Histórico e os Bens Materiais e Imateriais em Pernambuco e no Brasil. No norte, a presença da floresta amazônica é considerada na elaboração dos currículos, originando disciplinas como Ecologia da Amazônia aplicada ao Turismo, no caso da 
UFPA e uma disciplina bem peculiar presente no Centro Universitário do Norte, denominada Princípios de Alojamentos de Floresta.

Neste contexto de adaptar o curso à realidade local, no questionário respondido pela Coordenação do Curso da Universidade Federal de Pernambuco é transcrito um trecho da justificativa do Projeto Pedagógico Curricular do curso:

\begin{abstract}
$E$ evidente o interesse turístico que o Nordeste vem despertando $e$ atraindo pessoas dos mais diversos países. Os estados nordestinos vêm investindo na divulgação do turismo, reconhecendo-o como atividade de destaque fundamental ao desenvolvimento da região. Pernambuco vem se consolidando nesse esforço para atrair recursos, criando comissões e programas específicos que possibilitem o incremento da atividade turística do Estado. No entanto, uma área ainda deixa a desejar: a formação do profissional de turismo em nível superior, com sólida formação cultural-humanística, domínio de idiomas e conhecimentos técnicos. Neste contexto, torna-se fundamental o papel da Universidade como formadora de mão-deobra especializada capaz de prover uma sólida formação, utilizando o conhecimento de especialistas das mais diversas áreas. Apresentando-se assim como uma área de saber interdisciplinar $e$ interdepartamental, visando formar profissionais capazes e aptos a administrarem o Setor Turístico.
\end{abstract}

Continuando com as especificidades dos currículos, a Universidade Estadual do Oeste do Paraná é a única instituição entre as pesquisadas que oferece as disciplinas de Turismo e Educação e Turismo de Base Comunitária.

Destaca-se entre todos os currículos analisados o da Universidade Federal de Juiz de Fora. Nesta universidade o curso de Turismo está inserido no Bacharelado Interdisciplinar em Ciências Humanas. No formato curricular inicialmente o aluno completa este Bacharelado em um $1^{\circ}$ Ciclo e após completar este ciclo irá iniciar o $2^{\circ}$ Ciclo ou Profissionalizante no Turismo. O Ciclo Profissionalizante é composto pelo Tronco Comum e pela Ênfase que pode ser em Gestão de Empreendimentos Turísticos ou Patrimônio e Gestão de Destinos Turísticos. (www.ufjf.br/turismo/o-curso/curriculodo-curso/)

No que concerne à realização de estágio curricular, seguindo as Diretrizes Curriculares instituídas pelo MEC, é obrigatório e consta em todas as estruturas curriculares avaliadas. A carga horária mínima encontrada para o estágio entre os currículos pesquisados foi de 240 horas, sendo que pode ser realizado em um período único ou dividido em dois semestres dependendo da instituição.

Houve uma especificidade em relação ao curso da Universidade Federal do Pará, quando na questão sobre o motivo de início do curso, a resposta foi "abrir um curso de turismo na Amazônia." Nota-se aqui a tendência que parece crescente de se adequar o 
curso ao contexto social e ambiental. Nesta universidade a ênfase desde 2008 é em Ecoturismo e são oferecidas disciplinas como Ecologia da Amazônia Aplicada ao Turismo e História da Amazônia Aplicada ao Turismo.

Especificamente sobre a Universidade de Brasília, onde a pesquisadora realiza seu Mestrado, houve uma peculiaridade no motivo de criação do curso. De acordo com o Coordenador do Curso de Bacharelado em Turismo, Professor Doutor Luiz Carlos Spiller Pena:

\begin{abstract}
"O Centro de Excelência em Turismo já atuava na área de ensino de pós graduação, sendo este o foco. Entre 2008 e 2009 a partir do PROUNI, a Universidade criou novas possibilidades de se criarem novas graduações. Diante dessa possibilidade a Diretora do CET incentivou a abertura do curso de graduação. Houveram dois seminários de discussão nos quais foram trazidas pessoas de fora que colocaram posições com relação à questão do foco do curso, se deveria ter um viés mais profissional ou um viés profissionalacadêmico. Eu lembro que nestas discussões houve posicionamento de professores da Universidade dizendo que qualquer curso de graduação oferecido aqui observa a realidade local e regional, mas também deve preparar o aluno para atuar em outras realidades. Diante disso seria muito reducionismo se focar numa formação que tivesse o viés eminentemente técnico-profissional. Esta discussão foi o que balizou a construção do currículo.
\end{abstract}

\title{
4.4 Perspectiva do Mercado
}

Nesta seção serão abordadas as perspectivas do mercado de trabalho para o exercício da profissão do turismólogo. Para isto serão trazidas à análise as concepções da profissão de turismólogo de acordo com a Classificação Brasileira de Ocupações, do Ministério do Trabalho e Emprego e da Lei 12.591, de 18/01/2012. Complementando esta análise, será feita uma avaliação das competências e habilidades requeridas do profissional em turismo no setor público, tomando por referência os últimos concursos realizados pelo Ministério do Turismo e pela Embratur. E serão apresentados os dados resultantes de pesquisa feita com profissionais atuantes na área.

O embate universidade-empresa que está instalado há 40 anos no país significa, na verdade, o embate entre as necessidades "do mercado" e o desejo e o dever da universidade de formar pensadores (Barreto, Tamanini e da Silva, 2004, p. 45). Foi a partir deste confronto que se pensou em aliar o estudo das estruturas curriculares à efetiva prática profissional. Por isto que serão trazidas as definiçõos do que é a atividade do turismólogo de acordo com a visão do mercado.

De acordo com a Classificação Brasileira de Ocupações do Ministério do Trabalho e Emprego, os Turismólogos são os profissionais que: 
Dirigem como representantes dos proprietários, ou acionistas, ou por conta própria, as atividades dos serviços de turismo, de alojamento e de alimentação. Planejam e executam projetos e programas inerentes a atividade turística buscando o desenvolvimento sustentável e o fomento do turismo. Para tanto, definem planos, políticas e diretrizes, traçam e executam planos de negócios. Buscam produzir os melhores resultados através de pesquisas e análises de mercado e garantem a qualidade de produtos e serviços oferecidos. (BRASIL. Ministério do Trabalho e Emprego).

Estes profissionais também podem ser denominados como: analista de turismo, consultor em turismo, gestor em turismo ou planejador de turismo. Verifica-se que assim como na abordagem curricular, na conceituação profissional também está presente a interdisciplinaridade, visto que o profissional pode atuar na área de gestão, planejamento, consultoria ou pesquisa.

Na Classificação Brasileira de Ocupações não são definidas as competências e habilidades necessárias ao exercício da profissão de turismólogo. No entanto, como as atividades estão delimitadas nas áreas de gestão, consultoria e planejamento, entende-se que os conteúdos necessários a esta atuação são desenvolvidos nas estruturas curriculares que foram estudadas, bem como fazem parte das Diretrizes Curriculares do Ministério da Educação.

A Lei 12.591, de 18/01/2012 (Anexo B), que reconhece a profissão de Turismólogo, da mesma forma que a Classificação Brasileira de Ocupações, não delimita exatamente a área de atuação do profissional, sendo bastante amplas as atividades possíveis de serem desenvolvidas por ele. Apenas para mencionar algumas das atividades listadas na Lei, em seu artigo $2^{\circ}$ e Incisos que seguem:

\footnotetext{
XII - formular programas e projetos que viabilizem a permanência de turistas nos centros receptivos;

XIII - organizar eventos de âmbito público e privado, em diferentes escalas e tipologias;

XIV - planejar, organizar, controlar, implantar, gerir e operacionalizar empresas turísticas de todas as esferas, em conjunto com outros profissionais afins, como agências de viagens e turismo, transportadoras e terminais turísticos, organizadoras de eventos, serviços de animação, parques temáticos, hotelaria e demais empreendimentos do setor;

XV - planejar, organizar e aplicar programas de qualidade dos produtos e empreendimentos turísticos, conforme normas estabelecidas pelos órgãos competentes.
}

Esta Lei não limita o exercício profissional a quem tenha formação específica em Turismo. Desta forma, profissionais egressos de outras áreas, mesmo que sem afinidade podem atuar profissionalmente na área do turismo. 
A partir dos questionários respondidos pelos turismólogos (Apêndice B) atuantes no setor do turismo, observa-se que há uma unanimidade em relação à pergunta que trata do equilíbrio entre teoria e prática dos conteúdos abordados nos currículos dos cursos de bacharelado em Turismo. As respostas mostram que na maioria dos cursos os estudantes sentiram falta de equilíbrio entre as duas abordagens. Porém há um dado apreendido destas respostas que se considera positivo e curioso. A maior parte dos estudantes sentiu uma falta maior de atividade prática durante o curso, apesar de todos terem o estágio obrigatório. Inclusive, alguns respondem que o curso tinha foco em planejamento e isto tornava difícil a ocorrência de atividades práticas. Este dado mostra que os cursos de bacharelado em Turismo estão desmistificando a ideia inicial do senso comum, de que são cursos focados em formação técnica e operacional. A pergunta foi: considera que os conteúdos abordados tiveram equilíbrio entre teoria e prática? Explique. Segue a transcrição de algumas das respostas obtidas:

"Sinceramente não sei, porque o curso é praticamente voltado para a área de planejamento, dificilmente algum aluno do curso trabalha com planejamento, até porque é uma área muito restrita em nosso país".

"Há um equilibrio, porém acredito que havendo uma maior vivencia na prática, traria mais segurança na hora de escolher a aérea a seguir".

"Atuo na área de agencia, no período que cursei a faculdade o nosso curso era voltado ao planejamento e ao ecoturismo. Portanto senti falta da vivencia de agencia, que é muito diferente da teoria".

"No meu curso houve pouca prática, já que fomos poucas vezes para campo pesquisar. Portanto eu acredito que só houve teoria."

"As práticas durante o curso foram sem dúvida o mais interessante e produtivo do curso. Falta de interesse de grande parte dos alunos interfere na teoria ensinada durante o curso. Acredito que se o nível de interesse dos alunos em geral fosse melhor o curso seria mais produtivo e professores poderiam ir mais a fundo nas teorias".

"Não em sua totalidade. Apesar de constar, na grade curricular do curso, 4 disciplinas de estágio, essas não tinham um caráter tão prático. Me recordo que na faculdade organizávamos alguns eventos e jornadas de conhecimento (ou seja, práticas mais voltadas para o setor de eventos), fiz trabalho de campo para realização de inventário de um destino turístico de Minas, porém as outras disciplinas predominantemente foram teóricas (agenciamento, hotelaria, história da arte, geografia, etc.). Cabe destacar que a ênfase do curso de turismo da PUC/MG era, à época, em planejamento”. 
Em relação ao retorno financeiro da profissão foi feita a seguinte pergunta: Quanto à sua remuneração, você considera que está compatível inferior ou superior a outras áreas de formação? Por quê?

E sobre este questionamento verifica-se uma percepção geral dos profissionais de que a área do turismo não oferece retorno financeiro compatível com as exigências acadêmicas. Seguem algumas das respostas:

\begin{abstract}
"Poderia ser mais valorizado, por ser um curso que não tem tanta demanda o custo também se torna bem maior. Mas principalmente por termos que estar sempre atualizados e bem informados em relação a todos os acontecimentos do mundo. Pois isso influencia de alguma forma em nosso trabalho no dia a dia."
\end{abstract}

"Não. A maior parte dos meus colegas de graduação não trabalham na área pela baixa remuneração oferecida pelo mercado. Quanto aos alunos, somente os alunos que se tornaram empreendedores estão satisfeitos com o mercado de turismo."

"Trabalho nos Estados Unidos e sou muito bem remunerada pelo meu trabalho. Mas no Brasil o que pagam na área do turismo é uma piada. Faz 8 anos que não moro no Brasil e durante esse período retornei algumas vezes e fiz algumas entrevistas. Os salários eram inferiores a $R \$ 2.000 "$ !

"Muito abaixo das outras áreas de formação. Atualmente estou estudando administração e tive a experiência de participar de um processo seletivo para estágio onde a remuneração seria o dobro do meu salário atual, trabalhando apenas 6 horas por dia."

"Inferior, pois trabalhamos constantemente com gerenciamento de crise e afins. E a base de remuneração de um agente é a coix, sendo variável."

"Acho que a minha remuneração com profissional do turismo ainda é bem baixa pois ainda não me sustento com a profissão.”

"Como qualquer profissional sendo formado em Turismo ou não, pode desempenhar esta função, acredito que seja um dos principais motivos da não valorização do Turismólogo, e por isso a baixa remuneração."

"Inferior, tanto na área de agência quanto em outras dentro do turismo. Trabalhei com hotelaria e é visível a grande exigência que as empresas fazem, o que não condiz com o salário no final do mês."

Os questionários respondidos mostram que os profissionais entendem que, de maneira geral, há uma ampla oferta de disciplinas nos cursos de turismo que, no entanto, não são aprofundadas. O resultado que talvez sintetize as percepções trazidas pelos turismólogos à respeito da formação acadêmica refere-se ao conteúdo curricular, 
que segundo eles, é insuficiente para habilitar ao exercício profissional. Para oitenta e três por cento dos profissionais questionados, a maior parte do conhecimento é adquirida na prática profissional. O gráfico 4.1 apresenta as principais percepções relatadas pelos turismólogos.

Gráfico 4.1 Percepções dos Turismólogos

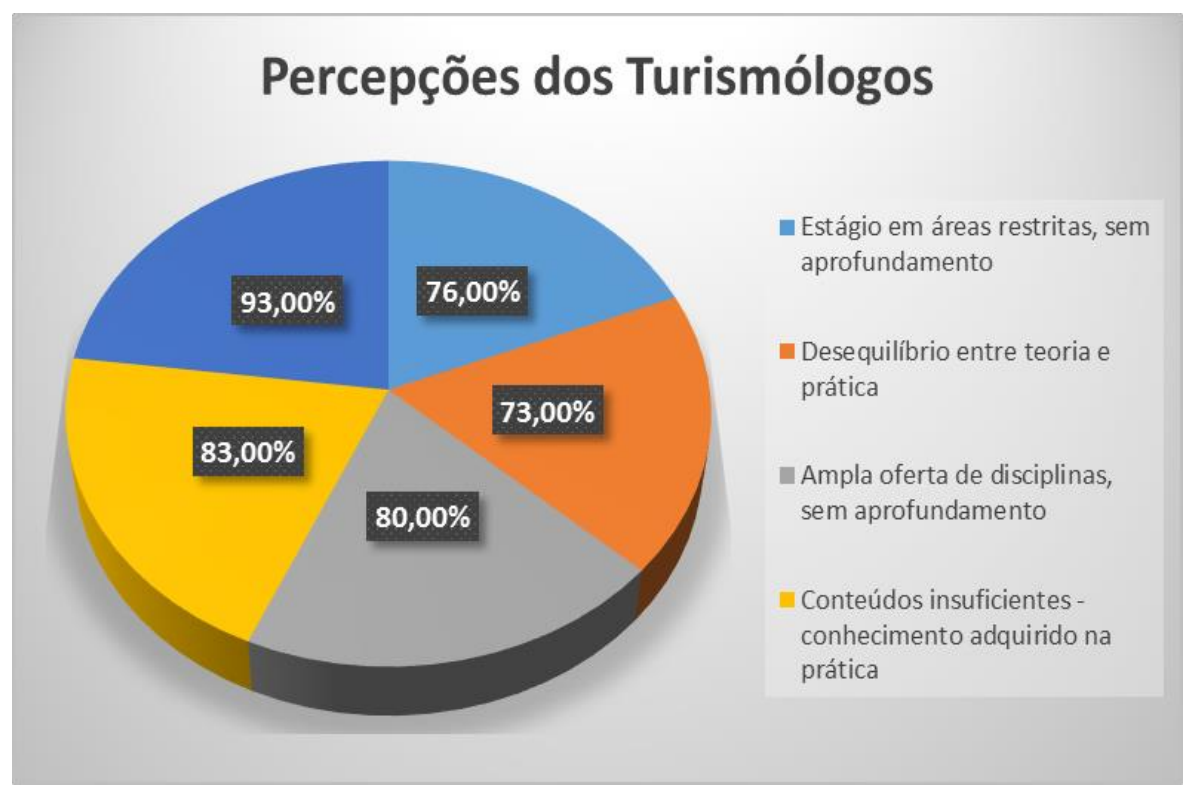

\subsubsection{Setor Público}

Com o fim de obtenção dos requisitos e demanda para atuação na área pública do turismo foi selecionado o concurso realizado pelo Ministério do Turismo em 2013 e o concurso realizado pela Embratur em 2010.

O concurso de Edital ESAF no 79, de 06 de Dezembro de 2013 (Anexo C) realizado pelo Ministério do Turismo, oferecia vagas específicas para profissionais com formação em Ciências Contábeis, Engenharia e Estatística. Além destes cargos, havia ofertas de vagas para profissionais com formação em qualquer área de graduação. Em uma instituição de âmbito nacional que tem como foco a organização e planejamento da atividade turística, entende-se que haveria a busca por profissionais com conhecimentos e habilidades construídas a partir do estudo da área. No entanto, não foi o que ocorreu neste concurso, não sendo ofertadas vagas específicas para turismólogos. 
Da mesma forma, o Edital $n^{\circ}$ 1, de 5 de Novembro de 2010 (Anexo D), de concurso realizado pela EMBRATUR também ofertou vagas para profissionais com formação em outras áreas: Administração, Economia e Comunicação Social. Para os cargos de técnico especializado a formação exigida era em qualquer área de formação, conforme segue no extrato de edital abaixo.

\subsection{NÍVEL SUPERIOR}

\subsubsection{Cargo: ADMINISTRADOR (CÓDIGO 101)}

2.2.1.1. Requisitos: diploma, devidamente registrado, de conclusão de curso de graduação em Administração, fornecido por instituição de ensino superior reconhecida pelo Ministério da Educação, e registro no Conselho Regional de Administração.

2.2.1.2. Descrição sumária das atribuições: realizar estudos, análises, interpretações, planejamento, execução, coordenação e controle de trabalhos nos campos da administração, da logística, do orçamento e finanças, da gestão do trabalho e de materiais; implementar programas e projetos; elaborar planejamento organizacional; promover estudos de racionalização e controlar o desempenho organizacional; e prestar assessoria administrativa.

\subsubsection{Cargo: ECONOMISTA (CÓDIGO 102)}

2.2.2.1. Requisitos: diploma, devidamente registrado, de conclusão de curso de graduação em Economia, fornecido por instituição de ensino superior reconhecida pelo Ministério da Educação, e registro no Conselho Regional de Economia.

2.2.2.2. Descrição sumária das atribuições: realizar atividades de planejamento, supervisão, coordenação, orientação, elaboração de projetos e execução especializada de trabalhos referentes à pesquisas e análises econômicas nacionais e internacionais, sobre comércio, indústria, finanças, estruturas patrimoniais e investimentos nacionais e estrangeiros.

2.2.3. Cargo: TÉCNICO EM COMUNICAÇÃO SOCIAL (CÓDIGO 103)

2.2.3.1. Requisitos: diploma, devidamente registrado, de conclusão de curso de graduação em Comunicação Social, fornecido por instituição de ensino superior reconhecida pelo Ministério da Educação, e registro no respectivo órgão de classe.

2.2.3.2. Descrição sumária das atribuições: realizar atividades de supervisão, coordenação e execução em grau de maior complexidade, de trabalhos de relações públicas, redação, com ou sem comentários, de supervisão de trabalhos de revisão, de coleta e preparo de informações, para divulgação oficial escrita, falada ou televisionada.

2.2.4. Cargo: TÉCNICO ESPECIALIZADO II (CÓDIGO 104)

2.2.4.1. Requisitos: diploma, devidamente registrado, de conclusão de curso de graduação em qualquer área de conhecimento, fornecido por instituição de ensino superior reconhecida pelo Ministério da Educação.

2.2.4.1.1. Idioma Complementar: Inglês.

2.2.4.2. Descrição sumária das atribuições: realizar atividades de supervisão, coordenação, pesquisa, planejamento e organização das atividades de sua área de atuação, analisar e desenvolver projetos de acordo com orientações e critérios definidos. Emitir pareceres técnicos e efetuar estudos.

2.2.4.3. Número de vagas: 19 (dezenove) vagas para contratação imediata e 95 (noventa e cinco) vagas para formação de cadastroreserva. 


\subsubsection{Cargo: TÉCNICO ESPECIALIZADO IV (CÓDIGO 105)}

2.2.5.1. Requisitos: diploma, devidamente registrado, de conclusão de curso de graduação em qualquer área de conhecimento, fornecido por instituição de ensino superior reconhecida pelo Ministério da Educação.

2.2.5.1.1. Idioma Complementar: Espanhol.

2.2.5.2. Descrição sumária das atribuições: realizar atividades de supervisão, coordenação, pesquisa, planejamento e organização das atividades de sua área de atuação, analisar e desenvolver projetos de acordo com orientações e critérios definidos. Emitir pareceres técnicos e efetuar estudos.

Este direcionamento mostra que no setor público há o mesmo direcionamento da legislação profissional existente do turismólogo, na qual não é exclusivo aos bacharéis em turismo o exercício da atividade profissional relacionada com a área. Este cenário aparentemente mostra que as competências necessárias para atuar na área do turismo turística poderiam ser desenvolvidas na prática profissional diária, sem a reflexão teórica abordada na academia.

\subsubsection{Descompassos e convergências entre o conteúdo e a prática}

Com os resultados obtidos pela pesquisa foi possível verificar que há uma demanda no exercício profissional que muitas vezes não é atendida no meio acadêmico. A percepção dos profissionais de que há uma carência na preparação técnica para atuação em serviços de agenciamento, por exemplo, mostra um dos conflitos existentes entre a teoria do conhecimento construído e a prática profissional.

Por outro lado, o mercado parece reforçar a visão de que não seria um diferencial a formação acadêmica para atuação na atividade turística, dado os relatos de turismólogos e os requisitos e áreas de formação solicitados em instituições públicas.

Pelo lado da academia observa-se uma tendência crescente em oferecer conteúdos que ultrapassem a formação operacional, que apresenta viés excessivamente técnico e com foco somente na prática. É o caso das disciplinas voltadas ao planejamento, meio ambiente, entre outras. Isto mostra uma característica positiva no esforço de construir um modelo curricular para a reflexão do fenômeno do turismo e não apenas para atender ao que é imposto pelo mercado. 


\section{CONSIDERAÇÕES FINAIS}

Esta pesquisa apresentou o estudo das relações entre os conteúdos acadêmicos, teóricos desenvolvidos nos cursos de bacharelado em Turismo e o exercício da profissão do turismólogo.

Ao iniciar esta pesquisa já se tinha o conhecimento de estudos feitos acerca das propostas curriculares e modelos educacionais dos cursos de Turismo. Assim como investigações que tratavam das questões de interdisciplinaridade e transdisciplinaridade nos currículos de Turismo e até mesmo sobre qual destas vertentes seria mais aplicável para estes currículos. Sabia-se também que estas discussões são recentes e ainda se encontram sem uma conclusão plena.

O intuito da pesquisa no entanto, não era debater se o melhor formato de aplicar a estrutura curricular seria pela inter ou transdisciplinaridade, tampouco propor um formato de currículo ideal, visto que este é um debate que ainda precisa se solidificar na área da educação para o turismo e ultrapassar a questão das disciplinas.

Entende-se então que esta é uma discussão que permanece atual e que apresenta pontos de vista diversos. Há correntes que defendem que determinadas disciplinas de caráter técnico não deveriam estar inseridas em um curso superior, deixando para este apenas os conteúdos teóricos voltados à reflexão do fenômeno do turismo.

Por outro lado, há a defesa de que o currículo deve ser o mais abrangente possível, permeando todas as áreas de atuação do turismo, mesmo que isto acarrete um conhecimento mais genérico e por vezes superficial.

O que se observou com esta pesquisa foi que historicamente o ensino do turismo passou por diferentes formatos. Tendo iniciado com foco mais voltado à formação técnica. Posteriormente, foi se apresentando como uma área de estudo teórico mais complexa e com o passar do tempo, incorporou também um conhecimento mais difundido sobre as características que envolvem a atividade turística.

Partindo do estudo das competências construídas pelo conhecimento adquirido, que constituíram a orientação para esta pesquisa, reforça-se que para a prática profissional considerada competente é necessário aliar a capacidade cognitiva de mobilizar teorias apreendidas com a habilidade de transportar este conhecimento para o exercício da profissão. 
Desta forma, a academia por meio dos seus cursos de bacharelado apresenta-se como o espaço acadêmico para acesso ao conhecimento devendo desenvolver esteconhecimento de forma crítica e reflexiva e relacionada a realidade local, propiciando um desenvolvimento contínuo das competências na prática profissional.

No que se refere aos currículos analisados os resultados do estudo, demonstraram uma tendência, ainda que na menor parte das instituições, de trabalhar os currículos ajustando-os à realidade social, econômica e cultural de onde estão inseridos.

Observou-se também que houve uma mudança no foco central das estruturas curriculares ao longo do tempo, visto que nas propostas curriculares iniciais era muito escassa a oferta de disciplinas que não tivessem relação direta com a atividade comercial do turismo. Atualmente, por exemplo, já se tem a presença considerável de disciplinas voltadas à sustentabilidade e ecoturismo.

Considerando a área comercial do turismo, abrangendo os setores de agenciamento, transportes e hospitalidade, a oferta de conteúdos curriculares é vasta e em geral, são nestas áreas em que o estágio obrigatório é realizado. Desta forma, para estas áreas de atuação pode-se considerar que existe uma preparação consolidada, unindo conhecimento teórico à prática profissional.

No que diz respeito à localização geográfica dos cursos analisados, observou-se que há um direcionamento de acordo com as características sócio-ambientais do lugar. Na Região Centro Oeste, por exemplo, há pouca inovação nos currículos, mantendo-se o padrão tradicional que é restrito as disciplinas de áreas clássicas como Administração, Economia, Geografia, História, dentre outras. Somente nas regiões sul e sudeste são ministradas disciplinas para gestão de pessoas e de qualidade, o que mostra conexão com as realidades locais, bastante voltadas a qualificação profissional e a prestação de serviços.

Do ponto de vista do mercado observou-se que supostamente há pouco reconhecimento do profissional que tem formação em turismo. O que se constatou é que profissionais de áreas diversas de formação podem atuar no papel do turismólogo. O turismólogo, por sua vez sente-se desprestigiado em relação à outras áreas de formação e desvalorizado em seu exercício profissional. Sente a falta de valorização do seu amplo conhecimento adquirido na academia e o retorno financeiro e possibilidade de ascensão profissional incompatíveis com as exigências de formação educacional.

O que se verificou de maneira geral foi que há aparentemente um descompasso entre a expectativa do estudante dos bacharelados de Turismo e a realidade do exercício 
profissional. Mudar este cenário não é papel que cabe somente à academia. Pode-se constatar pela pesquisa que no lado acadêmico os esforços já se iniciaram neste sentido.

Talvez haja a necessidade urgente de uma interação maior com o lado do mercado de trabalho de forma a conjugar os diferentes interesses na preparação de uma agenda de atividades colaborativas e ações estratégicas para uma formação sólida do profissional de turismo e que atenda a ambos os lados.

O turismólogo, no entanto, deve refletir e se perguntar se está buscando uma formação para o preenchimento de postos de trabalho apenas, ou se está comprometido com a atuação profissional para a atividade do turismo como ferramenta de desenvolvimento econômico, social e humano.

A busca pela reflexão da totalidade do fenômeno do turismo não pode ser imposta nem pela academia, nem pelo mercado de trabalho, mas deve ser característica inerente ao futuro profissional.

\section{Recomendações}

Pela pesquisa realizada, tanto do ponto de vista da academia, quanto no que se refere ao exercício da profissão do turismólogo no Brasil, parece haver uma inadequação ao contexto contemporâneo, independentemente da localização. Desta forma, dada a relevância crescente da atividade turística, inclusive como fator de desenvolvimento social pode ser o momento para uma reavaliação dos caminhos dos cursos de bacharelado em Turismo e também da atividade turística em todos os seus setores.

Se o conflito entre conteúdo e prática existe, esta é uma discussão que deve ser realizada nas instituições de ensino superior, bem como nas empresas públicas e privadas. Um debate que se restrinja somente à academia pode manter a desarmonia com a atuação profissional ou até acentuar as diferenças existentes. Por outro lado, uma discussão realizada somente do ponto de vista empresarial, seja do setor público ou privado, pode dificultar uma reflexão genuína sobre a totalidade do fenômeno do turismo, pois dessa forma estaria considerando apenas os interesses econômicos ou de mercado. Isso reforça a tese de que a discussão que deve ser realizada pela Academia, pelas Empresas e pelos profissionais.

Uma forma de se obter a avaliação constante do perfil profissional e do aproveitamento do conhecimento adquirido para a prática profissional é realizando um 
acompanhamento com os egressos dos cursos com a finalidade de entender as demandas que o exercício da profissão apresenta com o intuito de integrá-la à construção do conhecimento acadêmico.

A facilidade tecnológica possibilita o acesso aos recursos facilitadores do aprendizado o que proporciona que um tempo maior seja dedicado às reflexões teóricas. Desta forma, entende-se que os recursos tecnológicos que já são habitualmente presentes no exercício profissional do turismo, deva ser também um recurso amplo e de fácil acesso no meio acadêmico. Esta é uma possibilidade de aliar a construção do conhecimento teórico com a vivência da prática profissional.

Finalmente, no sentido de atender a uma preparação profissional contextualizada no cenário global e reflexiva sobre o fenômeno do turismo, recomenda-se que o estudo das relações internacionais que envolvem o turismo, deva ser incluído nos conteúdos programáticos dos cursos.

\section{Estudos Futuros}

Como geralmente ocorre em todas as pesquisas, nesta também, não foi possível abranger todos os aspectos referentes à formação do turismólogo e sua atividade profissional. Desta forma, sugere-se que seja realizado futuramente, um estudo abrangendo os cursos tecnológicos de formação em turismo.

Outra investigação que se considera importante seria a realização de um estudo dos modelos de currículos considerados diferenciados, como é o caso da Universidade Federal de Juiz de Fora. Entende-se que a estrutura curricular do curso de turismo desta universidade permite ao estudante maior maturidade na escolha profissional já que inicialmente irá cursar disciplinas dentro do Bacharelado de Humanidades e depois ingressar na ênfase escolhida do curso de turismo. Por isto considera-se que é válido o estudo aprofundado deste modelo curricular e do perfil dos egressos do curso, para verificar como o formato curricular oferecido se reflete na prática profissional.

Também se considera relevante como pesquisa futura, uma análise das percepções dos gestores de empresas públicas e privadas no setor do turismo. 


\section{REFERÊNCIAS BIBLIOGRÁFICAS}

ADORNO, T.W. Educação e Emancipação. In: ADORNO, T.W. Educação e Emancipação.Tradução de Wolfgang Leo Maar. Rio de Janeiro: Paz e Terra, 1995.

ALVES, Maria Lucia B. Reflexões Sobre a Pesquisa Qualitativa Aplicada ao Turismo. Turismo em Análise, São Paulo,v.22, n.3, dez. 2011. Disponível em: $\langle$ http://www.turismoemanalise.org.br/turismoemanalise/article/view/258/140> Acesso em 16 de ago. 2014.

ANSARAH, M. G. R. Formação e capacitação do profissional em turismo e hotelaria. São Paulo: Aleph, 2002.

APPLE, M. Ideologia e currículo. 3.ed. Porto Alegre: Artmed, 2006.

BARRETO, Margarita; TAMANINI, Elizabete; DA SILVA, Maria I. P. Discutindo o Ensino Universitário de Turismo. Campinas, SP: Papirus, 2004.

BENI, Mário C. Experiência Internacional do ensino de turismo e hotelaria Modelos para Avaliação. Turismo em Análise, São Paulo, v.3, n.2, p. 7-21, 1992.

In: CORDEIRO BRAGA, Débora (org.) 40 Anos de Turismo na ECA: Memórias e Análises. São Paulo: ECA/USP, 2013. p.27-33.

BRASIL. Ministério da Educação. Resolução n ${ }^{\circ}$ 13, de 24 de novembro de 2006. Disponível em: <http:// http://portal.mec.gov.br/cne/arquivos/pdf/rces13 06.pdf> Acesso em: 20 mar. 2015.

BRASIL. Ministério do Trabalho e Emprego. Classificação Brasileira de Ocupações. Disponível em: <http:// http://www.mtecbo.gov.br/cbosite/pages/pesquisas/BuscaPorTituloResultado.jsf>

Acesso em: 01 Jun. 2015.

BRASIL. Presidência da República. Lei no 12.591, de 18 de janeiro de 2012. Disponível em: <http://www.planalto.gov.br/CCIVIL_03/_Ato2011-2014/2012/Lei/L12591.htm> Acesso em: 14 jul.2013.

BUSTELO, Francisco E.; FERNANDEZ, Carmen D.; TOMÁS, Francisco J.Q. Higher Education of tourism in Spain and its adaptation to the European higher education. Revista de Administração Pública, Rio de Janeiro, v.44, n.5, p.1191-1223, set./out. 2010.

BUSBY, Graham; FIEDEL, Daniela. A Contemporany Review of Tourism Degrees in the United Kingdom. Journal of Vocational Education and Training, v. 53, n.4, 2001.

CARVALHO, Edmilson. A totalidade como categoria central na dialética marxista. Outubro. Revista do Instituto de Estudos Socialistas, n.15, p. 177-193, $1^{\circ}$ semestre 2007. Disponível em: <http://www.revistaoutubro.com.br/edicoes/15/Artigo_06.pdf> Acesso em 20 fev. 2015. 
COOPER, Chris; SHEPHERD, Rebecca; WESTLAKE, John. Educando os educadores em turismo: manual de educação em turismo e hospitalidade. São Paulo: Roca, 2001.

DA SILVA, Fabiano C.C; FABRIS, Cristine. A atuação do turismólogo na sociedade da informação. Revista Digital de Biblioteconomia e Ciência da Informação. Campinas, v.5, n.1, p 40-54, jul/dez. 2007 - ISSN: 1678-765X.

DOWBOR, Ladislau. Tecnologias do Conhecimento. Os desafios da Educação. São Paulo:Vozes, 2001.

EUGÊNIO, Benedito G.; Michael Apple e o Campo do Currículo. VI COLÓQUIO DO MUSEU PEDAGÓGICO. 2006.

FERREIRA JR., Amarilio; BITTAR, Marisa. A ditadura militar e a reforma universitária de 1968. Artigo publicado no Jornal Ciência \& Tecnologia, n.5, em setembro de $2004 \quad$ Disponível em <http://www.uniara.com.br/graduacao/jornalismo/jornalismo_cientifico/artigoaditaduramilitareareformauniversitariade1968.asp> Acesso em 07 ago. 2014.

FORMICA, S. European hospitality and tourism education: differences with the American model and future trends. International Journal of Hospitality Management, 15(4), p. 317-323, 1996.

GIL, Antonio Carlos. Como elaborar projetos de pesquisa. 4.ed. São Paulo: Atlas, 2002.

KUENZER, Acácia Z. Conhecimento e Competências no Trabalho e na Escola. Texto apresentado na Sessão Especial "Competências em educação e formação de professores" na 25 a Reunião Anual da ANPED, Caxambu-MG, 2000. Disponível em:http://www.anped.org.br/reunioes/25/ts25.htm. Acesso em 05 nov. 2014

LOHMANN, Guilherme. Síntese do Evento. CAUTHE 2004: pesquisa em turismo e hotelaria na Austrália. E o Brasil com isso? Disponível em <http:// http://www.turismoemanalise.org.br/turismoemanalise/article/view/452> Acesso em 02 Apr. 2015.

MARCONI, Marina de Andrade; LAKATOS, Eva M. Fundamentos da metodologia científica. 5.ed. São Paulo: Atlas, 2003.

MATIAS, Marlene. Turismo. Formação e Profissionalização. 30 Anos de História. Barueri: Manole, 2002

MOESCH, Marutschka M. Para além das disciplinas: o desafio do próximo século. In: GASTAL, Susana (Org.). Turismo Investigação e Crítica. São Paulo: Contexto, 2002. p. $25-44$.

MOLINA, Sérgio. Conceptualización del Turismo. México: Limusa, Noriega Editores, 2000. 
NECHAR, Marcelino C.; CORTÉS, Maribel L. Apuntes para la investigación turística. Chetumal: Universidad de Quintana Roo, 2006.NETTO, João Paulo. Introdução ao Estudo do Método de Marx. São Paulo: Expressão Popular, 2011.

OLIVEIRA, Edilson Moreira; ALMEIDA, José Luis Vieira; ARNONI, Maria Eliza Brefere. Mediação Dialética na Educação Escolar: teoria e prática. São Paulo: Edições Loyola. 2007.

ROCHA, Arlindo N. Currículo Escolar. Uma visão histórica da evolução do conceito de Currículo Escolar. Disponível em:<http:// http://www.webartigos.com/artigos/curriculo-escolar-uma-visao-historica-da-evolucaodo-conceito-de-curriculo-escolar/123546/\#ixzz3AlWuO2XS > Acesso em: 01Mai.2015.

SOGAYAR, Roberta L.; REJOWSKI, Mirian. Ensino Superior em Turismo. Em busca de novos paradigmas educacionais: problemas, desafios e forças de pressão. Revista Turismo Visão e Ação, Itajaí, v.13, n. 3, p. 282-298, set./dez. 2011. Disponível em <http//www.univali.br/revistaturismo> Acesso em: 08 apr. 2015.

SOFIQUE, Mir Abdul. Tourism education in India: Challenges and Opportunities in the Global context. p.1-23. Disponível em <http:// https://www.academia.edu/1882194/Tourism_education_in_India_Challenges_and_Op portunities_in the Global_context> Acesso em: 25 apr. 2015.

SUÁREZ, Laura P. Formación Profesional, Educación Superior y Ocupación en el Campo del Turismo (Reflexiones sobre la situación que se da em México). In: GARCÍA, Maribel O; DE LOS MONTEROS, Gerardo N. E. Entorno del Turismo. Perspectivas. Toluca: Universidad Autónoma del Estado de México. 2004. p.93-116.

TEIXEIRA, Anísio. Ensino superior no Brasil: análise e interpretação de sua evolução até 1969. Rio de Janeiro: Editora da Fundação Getúlio Vargas, 1989. 212p.

TEIXEIRA, Rivanda M.; FLETCHER, John; WESTLAKE, John. Ensino Superior em Turismo: Experiência do Reino Unido. Turismo em Análise, São Paulo, v.11, n. 2, p.14-37, nov.2000.

TRIVIÑOS, Augusto N.S. A dialética materialista e a prática social. Movimento, Porto Alegre, v.12, n. 02, p. 121-142, maio/agosto de 2006.

Introdução à Pesquisa em Ciências Sociais. A Pesquisa Qualitativa em Educação. São Paulo: Atlas, 1987.

TURISMÓLOGO. In: WIKIPÉDIA, a enciclopédia livre. Flórida: Wikimedia Foundation, 2014. Disponível em: <http://pt.wikipedia.org/w/index.php?title=Turism\%C3\%B3logo\&oldid=39115928>. Acesso em: 28 ago. 2014.

VELÁSQUEZ, Rosaluz. Pensar y enseñar sobre el turismo. Educación y turismo. In: GARCÍA, Maribel O.; DE LOS MONTEROS, Gerardo N. E. Entorno del Turismo. Perspectivas. Toluca: Universidad Autónoma del Estado de México. 2004. p.117-140. 


\section{BIBLIOGRAFIA}

AIREY, David; TRIBE, John. Educação Internacional em Turismo. São Paulo: Senac, 2008.

ARBACHE, Jorge Saba. O Mercado de Trabalho na Atividade Econômica do Turismo no Brasil. Brasília: Universidade de Brasília, 2001.

AVENA, Biagio M. Turismo, Educação e Acolhimento. Um Novo Olhar. São Paulo: Roca, 2006.

BENI, Mário Carlos. O profissional de turismo na sociedade pós-industrial. Carta aberta aos estudantes, futuros profissionais. In: GASTAL, Susana (Org.) et al. Turismo e Investigação Crítica. SãoPaulo: Contexto, 2002. p. 93-110.

BRIDI. Guilherme; DOS SANTOS, Márcia M. C. Formação e atuação do turismólogo no cenário das agências de turismo: contrapondo competências. Porto Alegre: EDIPUCRS, Editora Universitária Metodista IPA, 2012.

DEGRAZIA, Carolina F. Construindo competências na formação profissional em turismo. Disponível em:

<http://periodicodeturismo.com.br/site/artigo/pdf/Construindo\%20Compet\%C3\%AAnci as $\% 20 \mathrm{na} \% 20 \% 20$ Forma $\% \mathrm{C} 3 \% \mathrm{~A} 7 \% \mathrm{C} 3 \% \mathrm{~A} 30 \% 20$ Profissional $\% 20 \mathrm{em} \% 20$ Turismo.pdf

$>$ Acesso em 05 mai. 2014.

DEMO, Pedro. Ciência, ideologia e poder: uma sátira às ciências sociais. São Paulo : Atlas. 1988.

DENCKER, Ada F. M. Estado e Educação no Brasil: o Caso do Ensino do Turismo. In: XXIX CONGRESSO BRASILEIRO DE CIÊNCIAS DA COMUNICAÇÃO, 2006, Brasília: Universidade de Brasília.

DENCKER, Ada F. M. Métodos e técnicas de pesquisa em turismo. São Paulo: Futura, 2000.

DENCKER, Ada F. M. Pesquisa e Interdisciplinaridade no Ensino Superior. Uma Experiência no Curso de Turismo. São Paulo: Aleph, 2002.

DE OLIVEIRA, B. G; ZARDO, E. F.; MICHELON, R. Turismólogo: Identidade, Oportunidades e Novos Cenários

DUTRA, Luiz Henrique de A. Epistemologia da aprendizagem. Rio de Janeiro: DP\&A, 2002.

E SILVA, Erly M. de C.; TRENTIN, Fábia; MORAES, Cláudia C. de A. Panorama dos Cursos de Turismo das Universidades Públicas Federais da Região Sudeste do Brasil. In: SEMINÁRIO DA ASSOCIAÇÃO BRASILEIRA DE PESQUISA E PÓSGRADUAÇÃO EM TURISMO, 7, 2010, São Paulo. Disponível em <http://www.anptur.org.br/ocs/index.php/seminario/2010/paper/view/639> Acesso em: 26 mai. 2014. 
FREIRE, Paulo. Pedagogia da Autonomia: Saberes Necessários À Prática Educativa. São Paulo: Paz e Terra, 2008.

GAZOLA, Leandro. O papel do turismólogo frente ao desenvolvimento turístico nacional.

Disponível em: $<$ http://www.trilhaseaventuras.com.br/diarioviagem/viagem.asp?id=156\&id_colunis $\underline{\text { ta }=14>}$. Acesso em 12 ago. 2012.

GRAMSCI, Antonio. Os intelectuais e a organização da cultura. Rio de Janeiro: Civilização Brasileira, 1991.

JAFARI, Jafar. La Cientifizacion Del Turismo. In: Estudios $\mathrm{y}$ Perspectivas em Turismo. CIET, 1994. p. 7-29.

KRIPPENDORF, Jost. Sociologia do Turismo: para uma nova compreensão do lazer e das viagens. São Paulo: Aleph, 2000.

LAGE, Beatriz Helena Gelas. Turismo: teoria e prática. São Paulo: Atlas, 2000.

LEITE, Ricardo A. C. Turismo: A Necessidade de Profissionalização. Disponível em: $\langle$ http://www.revistaturismo.com.br/artigos/profissionalizacao.html >. Acesso em $13 \mathrm{dez}$. 2012.

MAFFESOLI, Michel. Sobre o Nomadismo. Vagabundagens Pós Modernas. Rio de Janeiro: Record, 2001.

MOESCH, Marutschka M. Epistemologia Social do Turismo. São Paulo: USP, 2004, v.1 e v.2. Tese (Doutorado) - Programa de Pós-Graduação em Relações Públicas, Propaganda e Turismo, Escola de Comunicação e Arte, Universidade de São Paulo.

MOESCH, Marutschka et al. Turismo: 9 Propostas para um saber-fazer. Porto Alegre: EDIPUCRS, 2000.

MOESCH, Marutschka M. Para além das disciplinas: o desafio do próximo século. In: GASTAL Susana (Org.). Turismo Investigação e Crítica. São Paulo: Contexto, 2002, p. 25-44.

MOTA, Keila C. N.; DOS ANJOS, Francisco A. Análise dos Cursos Superiores de Turismo no Nordeste Brasileiro: Bacharelado versus Tecnológico. Anais do VII Seminário em Pesquisa em Turismo do Mercosul; 2012 Nov 16-17; Caxias do Sul.

NASCIMENTO, M. E. M.; da Silva, A. Planejamento e desenvolvimento de um ambiente virtual como instrumento de promoção regional e internacional do turismo. Revista Cenário, v. 1, p. 94, 2013.

REJOWSKI, M. Turismo e pesquisa científica: pensamento internacional x situação brasileira. 6.ed. (Coleção Turismo) Campinas, SP: Papirus, 2002.

SANTOS, Boaventura de Sousa. A universidade no século XXI: para uma reforma democrática e emancipatória da universidade. São Paulo: Cortez, 2004.

VERGNAUD, Gérard. A formação de competências profissionais. 


\section{ANEXO A \\ RESOLUÇÃO N 13, DE 24 DE NOVEMBRO DE 2006 (*) \\ Institui as Diretrizes Curriculares Nacionais do Curso de Graduação em Turismo e dá outras providências.}

\section{O Presidente da Câmara de Educação Superior do Conselho Nacional se}

Educação, no uso de suas atribuições legais, com fundamento no art. $9^{\circ}, \S 2^{\circ}$, alínea “c”, da Lei n 4.024, de 20 de dezembro de 1961, com a redação dada pela Lei n ${ }^{0}$ 9.131, de 25 de novembro de 1995, tendo em vista as diretrizes e os princípios fixados pelos Pareceres CNE/CES nº 776, de 3/12/97, e 583, de 4/4/2001, e as Diretrizes Curriculares Nacionais elaboradas pela Comissão de Especialistas de Ensino de Turismo - CEETur/DEPES, propostas ao CNE pela SESu/MEC, considerando o que consta dos Pareceres CNE/CES nºs 67, de 11/3/2003, 288, de 6/11/2003, e 210, de 8/7/2004, homologados pelo Senhor Ministro de Estado da Educação, respectivamente, em 2/6/2003, em 12/4/2004, e em 23/9/2004.

\section{RESOLVE:}

Art. $1^{\circ}$ A presente Resolução institui as Diretrizes Curriculares Nacionais do Curso de Graduação em Turismo, Bacharelado, a serem observadas pelas Instituições de Educação Superior em sua organização curricular.

Art. $2^{\circ}$ A organização do curso de que trata esta Resolução se expressa através do seu Projeto Pedagógico, abrangendo o perfil do formando, as competências e habilidades, os componentes curriculares, o estágio curricular supervisionado, as atividades complementares, o sistema de avaliação, a monografia, o projeto de iniciação científica ou o projeto de atividade como Trabalho de Conclusão de Curso - TCC, componente opcional da IES, além do regime acadêmico de oferta e de outros aspectos que tornem consistente o referido projeto pedagógico.

$\S 1^{\circ} \mathrm{O}$ projeto pedagógico do curso, além da clara concepção do curso de graduação em Turismo, com suas peculiaridades, seu currículo pleno e sua operacionalização, abrangerá, sem prejuízo de outros, os seguintes elementos estruturais: 
I - objetivos gerais do curso, contextualizados em relação às suas inserções institucional, política, geográfica e social;

II - condições objetivas de oferta e a vocação do curso;

III - cargas horárias das atividades didáticas e da integralização do curso;

IV - formas de realização da interdisciplinaridade;

V - modos de integração entre teoria e prática;

VI - formas de avaliação do ensino e da aprendizagem;

VII - modos da integração entre graduação e pós-graduação, quando houver;

VIII - incentivo à pesquisa, como necessário prolongamento da atividade de ensino e como instrumento para a iniciação científica;

IX - concepção e composição das atividades de estágio curricular supervisionado, suas diferentes formas e condições de realização, observado o respectivo regulamento;

$\mathrm{X}$ - concepção e composição das atividades complementares.

$\S 2^{\circ} \mathrm{O}$ Projeto Pedagógico do curso de graduação em Turismo poderá admitir Linhas de Formação Específicas, direcionadas para diferentes áreas ocupacionais relacionadas com o turismo, abrangendo os segmentos ecológicos e ambientais, econômicos, culturais, de lazer, de intercâmbio de negócios e promoção de eventos e serviços, para melhor atender as necessidades do perfil profissiográfico que o mercado ou a região exigirem.

$\S 3^{\circ}$ Com base no princípio de educação continuada, as IES poderão incluir no Projeto Pedagógico do curso o oferecimento de cursos de pós-graduação lato sensu, nas respectivas modalidades, de acordo com as efetivas demandas do desempenho profissional.

Art. $3^{\circ} \mathrm{O}$ curso de graduação em Turismo deve ensejar, como perfil desejado do graduando, capacidade e aptidão para compreender as questões científicas, técnicas, sociais, econômicas e culturais, relacionadas com o mercado turístico, sua expansão e seu gerenciamento, observados os níveis graduais do processo de tomada de decisão, apresentando flexibilidade intelectual e adaptabilidade contextualizada no trato de situações diversas, presentes ou emergentes, nos vários segmentos do campo de atuação profissional.

Art. $4^{\circ} \mathrm{O}$ curso de graduação em Turismo deve possibilitar a formação profissional que revele, pelo menos, as seguintes competências e habilidades:

I - compreensão das políticas nacionais e regionais sobre turismo; 
II - utilização de metodologia adequada para o planejamento das ações turísticas, abrangendo projetos, planos e programas, com os eventos locais, regionais, nacionais e internacionais;

III - positiva contribuição na elaboração dos planos municipais e estaduais de turismo;

IV - domínio das técnicas indispensáveis ao planejamento e à operacionalização do Inventário Turístico, detectando áreas de novos negócios e de novos campos turísticos e de permutas culturais;

V - domínio e técnicas de planejamento e operacionalização de estudos de viabilidade econômico-financeira para os empreendimentos e projetos turísticos;

VI - adequada aplicação da legislação pertinente;

VII - planejamento e execução de projetos e programas estratégicos relacionados com empreendimentos turísticos e seu gerenciamento;

VIII - intervenção positiva no mercado turístico com sua inserção em espaços novos, emergentes ou inventariados;

IX - classificação, sobre critérios prévios e adequados, de estabelecimentos prestadores de serviços turísticos, incluindo meios de hospedagens, transportadoras, agências de turismo, empresas promotoras de eventos e outras áreas, postas com segurança à disposição do mercado turístico e de sua expansão;

X - domínios de técnicas relacionadas com a seleção e avaliação de informações geográficas, históricas, artísticas, esportivas, recreativas e de entretenimento, folclóricas, artesanais, gastronômicas, religiosas, políticas e outros traços culturais, como diversas formas de manifestação da comunidade humana;

XI - domínio de métodos e técnicas indispensáveis ao estudo dos diferentes mercados turísticos, identificando os prioritários, inclusive para efeito de oferta adequada a cada perfil do turista;

XII - comunicação interpessoal, intercultural e expressão correta e precisa sobre aspectos técnicos específicos e da interpretação da realidade das organizações e dos traços culturais de cada comunidade ou segmento social;

XIII - utilização de recursos turísticos como forma de educar, orientar, assessorar, planejar e administrar a satisfação das necessidades dos turistas e das empresas, instituições públicas ou privadas, e dos demais segmentos populacionais;

XIV - domínio de diferentes idiomas que ensejem a satisfação do turista em sua intervenção nos traços culturais de uma comunidade ainda não conhecida; 
XV - habilidade no manejo com a informática e com outros recursos tecnológicos;

XVI - integração nas ações de equipes interdisciplinares e multidisciplinares, interagindo criativamente face aos diferentes contextos organizacionais e sociais;

XVII - compreensão da complexidade do mundo globalizado e das sociedades pós-industriais, onde os setores de turismo e entretenimento encontram ambientes propícios para se desenvolverem;

XVIII - profunda vivência e conhecimento das relações humanas, de relações públicas, das articulações interpessoais, com posturas estratégicas do êxito de qualquer evento turístico;

XIX - conhecimentos específicos e adequado desempenho técnico-profissional, com humanismo, simplicidade, segurança, empatia e ética.

Art. $5^{\circ}$ Os cursos de graduação em Turismo deverão contemplar, em seu Projeto Pedagógico e em sua organização curricular, os seguintes campos interligados de formação:

I - Conteúdos Básicos: estudos relacionados com os aspectos sociológicos, antropológicos, históricos, filosóficos, geográficos, culturais e artísticos, que conformam as sociedades e suas diferentes culturas;

II - Conteúdos Específicos: estudos relacionados com a Teoria Geral do Turismo, Teoria da Informação e da Comunicação, estabelecendo ainda as relações do turismo com a administração, o direito, a economia, a estatística e a contabilidade, além do domínio de, pelo menos, uma língua estrangeira;

III - Conteúdos Teórico-Práticos: estudos localizados nos respectivos espaços de fluxo turístico, compreendendo visitas técnicas, inventário turístico, laboratórios de aprendizagem e de estágios.

Art. $6^{\circ}$ A organização curricular do curso de graduação em Turismo estabelecerá expressamente as condições para a sua efetiva conclusão e integralização curricular, de acordo com os seguintes regimes acadêmicos que as Instituições de Educação Superior adotarem: regime seriado anual; regime seriado semestral; sistema de créditos com matrícula por disciplina ou por módulos acadêmicos, com a adoção de pré-requisitos, atendido o disposto nesta Resolução.

Art. $7^{\circ}$ O Estágio Curricular Supervisionado é um componente curricular obrigatório, indispensável à consolidação dos desempenhos profissionais desejados, inerentes ao perfil do formando, devendo cada Instituição, por seus colegiados 
superiores acadêmicos, aprovar o respectivo regulamento de estágio, com suas diferentes modalidades de operacionalização.

$\S 1^{\circ} \mathrm{O}$ estágio de que trata este artigo poderá ser realizado na própria IES, mediante laboratórios especializados, sem prejuízo das atividades de campo, nos diversos espaços onde possam ser inventariados e coligidos traços significativos do acervo turístico, segundo as 3 diferentes áreas ocupacionais de que trata o $\S 2^{\circ}$ do art. $2^{\circ}$ desta Resolução, abrangendo as diversas ações teórico-práticas, desde que sejam estruturadas e operacionalizadas, de acordo com a regulamentação própria prevista no caput deste artigo.

$\S 2^{\circ}$ As atividades de estágio poderão ser reprogramadas e reorientadas de acordo com os resultados teórico-práticos gradualmente revelados pelo aluno, até que os responsáveis pelo estágio curricular possam considerá-lo concluído, resguardando, como padrão de qualidade, os domínios indispensáveis ao exercício da profissão.

Art. $8^{\circ}$ As Atividades Complementares são componentes curriculares que possibilitam o reconhecimento, por avaliação, de habilidades, conhecimentos e competências do aluno, inclusive adquiridas fora do ambiente acadêmico, abrangendo a prática de estudos e atividades independentes, transversais, opcionais, de interdisciplinaridade, especialmente nas relações com o mundo do trabalho, com as peculiaridades das diversas áreas ocupacionais que integram os segmentos do mercado do turismo, bem assim com as ações culturais de extensão junto à comunidade.

Parágrafo único. As Atividades Complementares se constituem componentes curriculares enriquecedores e implementadores do próprio perfil do formando, sem que se confundam com estágio curricular supervisionado.

Art. $9^{\circ} \mathrm{O}$ Trabalho de Conclusão de Curso - TCC é um componente curricular opcional da Instituição que, se o adotar, poderá ser desenvolvido nas modalidades de monografia, projeto de iniciação científica ou projetos de atividades centrados em áreas teórico-práticas e de formação profissional relacionadas com o curso, na forma disposta em regulamento próprio.

Parágrafo único. Optando a Instituição por incluir, no currículo do curso de graduação em Turismo, Trabalho de Conclusão de Curso - TCC, nas modalidades referidas no caput deste artigo, deverá emitir regulamentação própria, aprovada pelo seu Conselho Superior Acadêmico, contendo, obrigatoriamente, critérios, procedimentos e mecanismos de avaliação, além das diretrizes técnicas relacionadas com a sua elaboração. 
Art. 10. As Instituições de Educação Superior deverão adotar formas específicas e alternativas de avaliação, internas e externas, sistemáticas, envolvendo todos quantos se contenham no processo do curso, observados os aspectos considerados fundamentais para a identificação do perfil do formando. Parágrafo único. Os planos de ensino, a serem fornecidos aos alunos antes do início do período letivo, deverão conter, além dos conteúdos e das atividades, a metodologia do processo de ensino-aprendizagem, os critérios de avaliação a que serão submetidos e a bibliografia básica.

Art. 11. A carga horária dos cursos de graduação será estabelecida em Resolução específica da Câmara de Educação Superior.

Art. 12. As Diretrizes Curriculares Nacionais desta Resolução deverão ser implantadas pelas Instituições de Educação Superior, obrigatoriamente, no prazo máximo de dois anos, aos alunos ingressantes, a partir da publicação desta.

Parágrafo único. As IES poderão optar pela aplicação das DCN aos demais alunos do período ou ano subseqüente à publicação desta.

Art. 12. Tratando-se de curso de graduação, licenciatura plena, destinada à formação de professores para atuação na educação básica, os projetos pedagógicos observarão as Diretrizes Curriculares Nacionais próprias.

Art. 13. Esta Resolução entrará em vigor na data de sua publicação, revogandose a Resolução s/nº de 28 de janeiro de 1971.

\section{ANTÔNIO CARLOS CARUSO RONCA}

Presidente da Câmara de Educação Superior 


\section{ANEXO B \\ LEI 12.591, DE 18 DE JANEIRO DE 2012.}

Reconhece a profissão de Turismólogo e disciplina o seu exercício.

A PRESIDENTA DA REPÚBLICA Faço saber que o Congresso Nacional decreta e eu sanciono a seguinte Lei:

Art. $1^{\circ}$ (VETADO).

Art. $2^{-}$Consideram-se atividades do Turismólogo:

I - planejar, organizar, dirigir, controlar, gerir e operacionalizar instituições e estabelecimentos ligados ao turismo;

II - coordenar e orientar trabalhos de seleção e classificação de locais e áreas de interesse turístico, visando ao adequado aproveitamento dos recursos naturais e culturais, de acordo com sua natureza geográfica, histórica, artística e cultural, bem como realizar estudos de viabilidade econômica ou técnica;

III - atuar como responsável técnico em empreendimentos que tenham o turismo e o lazer como seu objetivo social ou estatutário;

IV - diagnosticar as potencialidades e as deficiências para o desenvolvimento do turismo nos Municípios, regiões e Estados da Federação;

$\mathrm{V}$ - formular e implantar prognósticos e proposições para o desenvolvimento do turismo nos Municípios, regiões e Estados da Federação;

VI - criar e implantar roteiros e rotas turísticas;

VII - desenvolver e comercializar novos produtos turísticos;

VIII - analisar estudos relativos a levantamentos socioeconômicos e culturais, na área de turismo ou em outras áreas que tenham influência sobre as atividades e serviços de turismo;

IX - pesquisar, sistematizar, atualizar e divulgar informações sobre a demanda turística;

$\mathrm{X}$ - coordenar, orientar e elaborar planos e projetos de marketing turístico;

XI - identificar, desenvolver e operacionalizar formas de divulgação dos produtos turísticos existentes; 
XII - formular programas e projetos que viabilizem a permanência de turistas nos centros receptivos;

XIII - organizar eventos de âmbito público e privado, em diferentes escalas e tipologias;

XIV - planejar, organizar, controlar, implantar, gerir e operacionalizar empresas turísticas de todas as esferas, em conjunto com outros profissionais afins, como agências de viagens e turismo, transportadoras e terminais turísticos, organizadoras de eventos, serviços de animação, parques temáticos, hotelaria e demais empreendimentos do setor;

$\mathrm{XV}$ - planejar, organizar e aplicar programas de qualidade dos produtos e empreendimentos turísticos, conforme normas estabelecidas pelos órgãos competentes;

XVI - emitir laudos e pareceres técnicos referentes à capacitação ou não de locais e estabelecimentos voltados ao atendimento do turismo receptivo, conforme normas estabelecidas pelos órgãos competentes;

XVII - lecionar em estabelecimentos de ensino técnico ou superior;

XVIII - coordenar e orientar levantamentos, estudos e pesquisas relativamente a instituições, empresas e estabelecimentos privados que atendam ao setor turístico.

Art. $3^{\circ}$ (VETADO).

Art. $4^{\circ}$ (VETADO).

Art. 5ํㅡㄹ Esta Lei entra em vigor na data de sua publicação.

Brasília, 18 de janeiro de 2012; 191ํ da Independência e 124º da República.

\section{DILMA ROUSSEFF}

José Eduardo Cardozo

Paulo Roberto dos Santos Pinto

Gastão Vieira Luís Inácio Lucena Adams

Este texto não substitui o publicado no DOU de 19.1.2012 e retificado em 20.1.2012 


\title{
ANEXO C
}

EDITAL ESAF N 79, DE 06 DE DEZEMBRO DE 2013

\author{
CONCURSO PÚBLICO PARA PROVIMENTO DE CARGOS DE ANALISTA \\ TÉCNICO-ADMINISTRATIVO, CONTADOR, ENGENHEIRO e ESTATÍSTICO DO \\ MINISTÉRIO DO TURISMO - Mtur
}

O DIRETOR-GERAL DA ESCOLA DE ADMINISTRAÇÃO FAZENDÁRIA, no uso de suas atribuições e considerando a subdelegação de competência outorgada à ESAF pela Portaria $n^{\circ} 79$, de 20/11/2013, do Subsecretário de Planejamento, Orçamento e Administração do Ministério do Turismo, publicada no DOU de 22/11/2013, divulga a abertura das inscrições e estabelece normas para a realização do concurso público autorizado pela Portaria $n^{\circ}$ 414, do Ministério do Planejamento, Orçamento e Gestão MP, publicada na Seção 1 do DOU de 31/10/2013, destinado a selecionar candidatos para o provimento de cargos de ANALISTA TÉCNICOADMINISTRATIVO, CONTADOR, ENGENHEIRO e ESTATÍSTICO, integrantes da estrutura do Plano Geral de Cargos do Poder Executivo - PGPE, instituído pela Lei n ${ }^{\circ} 11.907$, de 02/02/2009 e observadas às disposições contidas na Lei $n^{\circ} 12.277$ de 30/06/2010 Decreto $n^{\circ} 72.493$, de 19/07/1973, Decreto $n^{\circ} 6.944$, de 21/8/2009 e, ainda, os termos da Lei $n^{\circ} 8.112$, de 11/12/1990 e, em particular, as normas contidas neste Edital.

1 - DAS DISPOSIÇÕES PRELIMINARES 1.1 - O concurso visa ao provimento do número de vagas definido no subitem 1.2, ressalvada a possibilidade de acréscimo prevista no art. 11 do Decreto ${ }^{\circ}$ 6.944, de 21/8/2009, e será assim constituído: a) Prova 1 - Objetiva de Conhecimentos Básicos: de caráter seletivo, eliminatório e classificatório, valendo, no máximo, 80 pontos ponderados; b) Prova 2 - Objetiva de Conhecimentos Específicos: de caráter seletivo, eliminatório e classificatório, valendo, no máximo, 100 pontos ponderados. 1.2 Os cargos, a escolaridade, a taxa de inscrição e o número de vagas são os estabelecidos no quadro a seguir: Taxa de Inscrição: R \$ 90,00 Cargo / Escolaridade/ Número de vagas: Analista TécnicoAdministrativo Contador Engenheiro Estatístico Total UF de vagas Superior, em nível de graduação concluído em qualquer área. Superior, em nível de graduação, concluído em Ciências Contábeis, com registro no Conselho Regional de Contabilidade (CORECON). Superior, em nível de graduação, concluído em Engenharia, com registro no órgão de classe. Superior, em nível de graduação, concluído em Estatística, com registro no Conselho Regional de 
Estatística (CONRE). Ampla Def. Ampla Def. Ampla Def. Ampla Def. Ampla Def. DF 3523 - 912 - 493 Total 37310252 1.2.1- Regime e jornada de trabalho: o servidor será regido pelo Regime Jurídico Único dos Servidores Públicos Civil da União, de que trata a Lei $\mathrm{n}^{\circ} 8.112$, de 11/12/1990, com jornada de trabalho de 40 (quarenta) horas semanais. 1.2.2 - As vagas distribuídas por cargo, conforme o quadro constante do subitem 1.2, são independentes e não se comunicam para efeito da aprovação, classificação e da nomeação.

2 - DA REMUNERAÇÃO INICIAL DOS CARGOS: 2.1- Analista TécnicoAdministrativo e Contador: vencimento básico inicial: $\mathrm{R} \$ 1.990,22+\mathrm{R} \$ 2.257,60$ (80 pontos da GDPGPE) = R \$ 4.247,82 (quatro mil, duzentos e quarenta e sete reais e oitenta e dois centavos), sem incluir os benefícios (ticket-alimentação e vale-transporte). 2.2- Engenheiro e Estatístico (cargos integrantes do Plano de Carreira de Cargos do Poder Executivo (Lei $\mathrm{n}^{\mathrm{o}} 12.277$ de 30/06/2010)): vencimento básico inicial: R\$ $2.449,98+\mathrm{R} \$ 2.762,40(80$ pontos da GDACE) $=\mathrm{R} \$$ 5.212,38 (cinco mil, duzentos e doze reais e trinta e oito centavos), valores correspondentes à tabela da estrutura remuneratória especial de cargos específicos.

3 - DOS CARGOS: 3.1. ANALISTA TÉCNICO-ADMINISTRATIVO 3.1.1. Requisitos: diploma devidamente registrado de conclusão de curso de graduação de nível superior em qualquer área de formação, fornecido por instituição de ensino superior reconhecida pelo MEC. 3.1.2. Atribuições: planejar, supervisionar, coordenar, controlar, acompanhar e executar atividades técnicas e especializadas, de nível superior, necessárias ao exercício das competências constitucionais e legais a cargo do 2 Ministério do Turismo, bem como à implementação de processos e à realização de estudos e pesquisas na sua área de atuação, ressalvadas as atividades privativas de carreiras específicas. 3.2. CONTADOR 3.2.1. Requisitos: diploma devidamente registrado, de curso de graduação em Ciências Contábeis, e registro profissional no órgão de classe competente. 3.2.2. Atribuições: realizar atividades de execução qualificada, de trabalhos relativos à administração financeira e patrimonial, bem como à contabilidade e auditoria, compreendendo análise, registro e perícia contábeis, elaboração de balancetes, balanços e demonstrações contábeis com relação ao funcionamento da Administração Pública Federal. 3.3. ENGENHEIRO 3.3.1. Requisitos: diploma devidamente registrado de conclusão de curso de graduação de nível superior em Engenharia, fornecido por instituição de ensino superior reconhecida pelo MEC e registro profissional no órgão de classe competente. 3.3.2. Atribuições: 
executar atividades qualificadas, sob supervisão de trabalhos relativos a engenharia, fiscalização e construção, bem como à implementação de processos e à realização de estudos e pesquisas na sua área de atuação, ressalvadas as atividades privativas de carreiras específicas. 3.4. ESTATÍSTICO: 3.4.1. Requisitos: diploma devidamente registrado de conclusão de curso de graduação de nível superior em Estatística, fornecido por instituição de ensino superior reconhecida pelo MEC e registro profissional no órgão de classe competente. 3.4.2. Atribuições: executar atividades qualificadas, sob supervisão de trabalhos relativos à implementação de processos e à realização de estudos e pesquisas na sua área de atuação, ressalvadas as atividades privativas de carreiras específicas. 


\title{
ANEXO D \\ EMBRATUR - INSTITUTO BRASILEIRO DE TURISMO EDITAL No 1, DE 5 DE NOVEMBRO DE 2010
}

\begin{abstract}
CONCURSO PÚBLICO 1/2010 - PARA PROVIMENTO DE VAGAS E FORMAÇÃO DE CADASTRO-RESERVA EM CARGOS DE NÍVEL SUPERIOR E DE NÍVEL INTERMEDIÁRIO

A EMBRATUR - Instituto Brasileiro de Turismo, no uso de suas atribuições legais e considerando o disposto no Decreto n. ${ }^{\circ}$ 6.944, de 21 de agosto de 2009, na Portaria n. ${ }^{\circ}$ 228, de 12 de maio de 2010, publicada no Diário Oficial da União de 13 de maio de 2010, do Ministério do Planejamento, Orçamento e Gestão, que autoriza a realização do concurso, torna pública a realização de concurso público para provimento de vagas e formação de cadastro-reserva em cargos de nível superior e de nível intermediário, de acordo com a legislação pertinente e com o disposto neste edital e em seus anexos e nos editais subsequentes.
\end{abstract}

\section{DAS DISPOSIÇÕES PRELIMINARES}

1.1. O concurso público será regido por este edital e executado pela Fundação Universa.

1.2. O concurso público destina-se a selecionar candidatos para provimento de vagas e formação de cadastro-reserva nos cargos de nível superior e de nível intermediário descritos no item 2 deste edital.

1.2.1. Para todos os cargos, o cadastro-reserva somente será aproveitado mediante a abertura de novas vagas nos respectivos cargos, atendendo aos interesses de conveniência e de oportunidade da EMBRATUR.

1.2.2. As vagas para o concurso público serão distribuídas por área de conhecimento com vistas a atender a unidade da EMBRATUR, em Brasília/DF.

1.3. As provas referentes ao concurso público serão realizadas nas cidades de Brasília/DF, São Paulo/SP, Rio de Janeiro/RJ, Belo Horizonte/MG, Salvador/BA e Fortaleza/CE.

1.4. O concurso público será realizado em 1 (uma) etapa composta por 3 (três) fases, assim constituídas:

a) prova objetiva, de caráter eliminatório e classificatório, que será aplicada a todos os cargos;

b) prova discursiva, de caráter eliminatório e classificatório, que será aplicada a todos os cargos de nível superior;

c) avaliação de títulos e de experiência profissional, de caráter unicamente classificatório, que será aplicada a todos os cargos de nível superior.

1.5. Os candidatos aprovados e nomeados realizarão procedimentos pré-admissionais e exames médicos complementares, de caráter unicamente eliminatório, de responsabilidade da EMBRATUR.

1.6. Os horários mencionados no presente edital e nos demais editais a serem publicados para o certame obedecerão ao horário oficial de Brasília/DF.

1.6.1. É de exclusiva responsabilidade do candidato observar as diferenças de horário decorrentes de fuso horário ou adoção de horário de verão na cidade de realização da prova.

\section{DOS CARGOS}

2.1. Os cargos constantes deste item foram criados pelos seguintes atos normativos: Lei $\mathrm{n}^{\mathrm{o}} 11.356$, de 19 de outubro de 2006; Lei $\mathrm{n}^{\circ} 11.490$, de 20 de junho de 2007; e Lei $\mathrm{n}^{\circ}$ 11.907, de 2 de fevereiro de 2009.

2.2. NÍVEL SUPERIOR

2.2.1. Cargo: ADMINISTRADOR (CÓDIGO 101) 
2.2.1.1. Requisitos: diploma, devidamente registrado, de conclusão de curso de graduação em Administração, fornecido por instituição de ensino superior reconhecida pelo Ministério da Educação, e registro no Conselho Regional de Administração.

2.2.1.2. Descrição sumária das atribuições: realizar estudos, análises, interpretações, planejamento, execução, coordenação e controle de trabalhos nos campos da administração, da logística, do orçamento e finanças, da gestão do trabalho e de materiais; implementar programas e projetos; elaborar planejamento organizacional; promover estudos de racionalização e controlar o desempenho organizacional; e prestar assessoria administrativa.

2.2.1.3. Número de vagas: 5 (cinco) vagas para contratação imediata e 25 (vinte e cinco) vagas para formação de cadastro-reserva.

2.2.1.4. Jornada de trabalho: 40 (quarenta) horas semanais.

2.2.1.5. Remuneração: $\mathrm{R} \$ 3.943,65$ (três mil, novecentos e quarenta e três reais e sessenta e cinco centavos), composta de vencimento básico ( $\mathrm{R} \$ 2.986,85)$ + Gratificação de Desempenho de Atividade da EMBRATUR (R\$ 956,80).

2.2.2. Cargo: ECONOMISTA (CÓDIGO 102)

2.2.2.1. Requisitos: diploma, devidamente registrado, de conclusão de curso de graduação em Economia, fornecido por instituição de ensino superior reconhecida pelo Ministério da Educação, e registro no Conselho Regional de Economia.

2.2.2.2. Descrição sumária das atribuições: realizar atividades de planejamento, supervisão, coordenação, orientação, elaboração de projetos e execução especializada de trabalhos referentes à pesquisas e análises econômicas nacionais e internacionais, sobre comércio, indústria, finanças, estruturas patrimoniais e investimentos nacionais e estrangeiros.

2.2.2.3. Número de vagas: 5 (cinco) vagas para contratação imediata e 25 (vinte e cinco) vagas para formação de cadastro-reserva.

2.2.2.4. Jornada de trabalho: 40 (quarenta) horas semanais.

2.2.2.5. Remuneração: $\mathrm{R} \$ 4.834,22$ (quatro mil, oitocentos e trinta e quatro reais e vinte e dois centavos), composta de vencimento básico ( $\mathrm{R} \$ 2.331,02)$ + Gratificação de Desempenho de Atividade de Cargos Específicos (R \$ 2.503,20).

\subsubsection{Cargo: TÉCNICO EM COMUNICAÇÃO SOCIAL (CÓDIGO 103)}

2.2.3.1. Requisitos: diploma, devidamente registrado, de conclusão de curso de graduação em Comunicação Social, fornecido por instituição de ensino superior reconhecida pelo Ministério da Educação, e registro no respectivo órgão de classe.

2.2.3.2. Descrição sumária das atribuições: realizar atividades de supervisão, coordenação e execução em grau de maior complexidade, de trabalhos de relações públicas, redação, com ou sem comentários, de supervisão de trabalhos de revisão, de coleta e preparo de informações, para divulgação oficial escrita, falada ou televisionada. 2.2.3.3. Número de vagas: 5 (cinco) vagas para contratação imediata e 25 (vinte e cinco) vagas para formação de cadastro-reserva.

2.2.3.4. Jornada de trabalho: 40 (quarenta) horas semanais.

2.2.3.5. Remuneração: $\mathrm{R} \$ 3.943,65$ (três mil, novecentos e quarenta e três reais e sessenta e cinco centavos), composta de vencimento básico ( $\mathrm{R} \$ 2.986,85)$ + Gratificação de Desempenho de Atividade da EMBRATUR (R \$ 956,80).

2.2.4. Cargo: TÉCNICO ESPECIALIZADO II (CÓDIGO 104)

2.2.4.1. Requisitos: diploma, devidamente registrado, de conclusão de curso de graduação em qualquer área de conhecimento, fornecido por instituição de ensino superior reconhecida pelo Ministério da Educação.

2.2.4.1.1. Idioma Complementar: Inglês. 
2.2.4.2. Descrição sumária das atribuições: realizar atividades de supervisão, coordenação, pesquisa, planejamento e organização das atividades de sua área de atuação, analisar e desenvolver projetos de acordo com orientações e critérios definidos. Emitir pareceres técnicos e efetuar estudos.

2.2.4.3. Número de vagas: 19 (dezenove) vagas para contratação imediata e 95 (noventa e cinco) vagas para formação de cadastro-reserva.

2.2.4.4. Jornada de trabalho: 40 (quarenta) horas semanais.

2.2.4.5. Remuneração: $\mathrm{R} \$ 3.943,65$ (três mil, novecentos e quarenta e três reais e sessenta e cinco centavos), composta de vencimento básico ( $\mathrm{R} \$ 2.986,85)$ + Gratificação de Desempenho de Atividade da EMBRATUR (R\$ 956,80).

2.2.5. Cargo: TÉCNICO ESPECIALIZADO IV (CÓDIGO 105)

2.2.5.1. Requisitos: diploma, devidamente registrado, de conclusão de curso de graduação em qualquer área de conhecimento, fornecido por instituição de ensino superior reconhecida pelo Ministério da Educação.

2.2.5.1.1. Idioma Complementar: Espanhol.

2.2.5.2. Descrição sumária das atribuições: realizar atividades de supervisão, coordenação, pesquisa, planejamento e organização das atividades de sua área de atuação, analisar e desenvolver projetos de acordo com orientações e critérios definidos. Emitir pareceres técnicos e efetuar estudos.

2.2.5.3. Número de vagas: 16 (dezesseis) vagas para contratação imediata e 80 (oitenta) vagas para formação de cadastro-reserva.

2.2.5.4. Jornada de trabalho: 40 (quarenta) horas semanais.

2.2.5.5. Remuneração: $\mathrm{R} \$ 3.943,65$ (três mil, novecentos e quarenta e três reais e sessenta e cinco centavos), composta de vencimento básico (R\$ 2.986,85) + Gratificação de Desempenho de Atividade da EMBRATUR (R $\$ 956,80)$.

2.3. NÍVEL INTERMEDIÁRIO

2.3.1. Cargo: AGENTE ADMINISTRATIVO (CÓDIGO 201)

2.3.1.1. Requisitos: certificado, devidamente registrado, de conclusão de curso de nível médio (antigo segundo grau), fornecido por instituição de ensino reconhecida pelo Ministério da Educação.

2.3.1.2. Descrição sumária das atribuições: realizar atividades de apoio contábeis, convênios, logístico, financeiro, patrimonial; executar outras tarefas afins sob supervisão, fazendo uso de todos os equipamentos e recursos disponíveis para a consecução dessas atividades.

2.3.1.3. Número de vagas: 34 (trinta e quatro) vagas para contratação imediata e 170 (cento e setenta) vagas para formação de cadastro-reserva.

2.3.1.4. Jornada de trabalho: 40 (quarenta) horas semanais.

2.3.1.5. Remuneração: $\mathrm{R} \$ 1.950,23$ (um mil e novecentos e cinquenta reais e vinte e três centavos), composta de vencimento básico ( $\mathrm{R} \$ 1.327,83)$ + Gratificação de Desempenho de Atividade da EMBRATUR (R\$ 622,40). 


\section{APÊNDICE A \\ QUESTIONÁRIO PARA OS COORDENADORES DE CURSO}

Este apêndice apresenta o questionário aplicado junto aos coodenadores de curso.

Ilustríssimo(a) Senhor(a),

Estamos realizando uma pesquisa com o objetivo de investigar a relação entre as competências trabalhadas na formação acadêmica e as aptidões requisitadas pelo mundo do trabalho contemporâneo. Esta pesquisa faz parte da Dissertação de Mestrado intitulada Construção do Conhecimento do Turismo: competências necessárias para o exercício da profissão do Turismólogo. O Mestrado faz parte do Programa de Pós Graduação em Turismo do Centro de Excelência em Turismo da Universidade de Brasília.

Para tanto, agradeceríamos a especial gentileza de nos devolver o Questionário de Pesquisa (anexo). Informamos que será mantido o anonimato das Instituições, pois no relatório final, serão identificadas como instituição A, B ou C. Por esse motivo, pedimos sua atenção na fidedignidade das respostas.

Reafirmando a relevância dessa pesquisa, consideramos a sua resposta de suma importância para o estudo científico da educação em Turismo. Certos de sua colaboração, aguardamos sua valiosa participação.

Atenciosamente, 


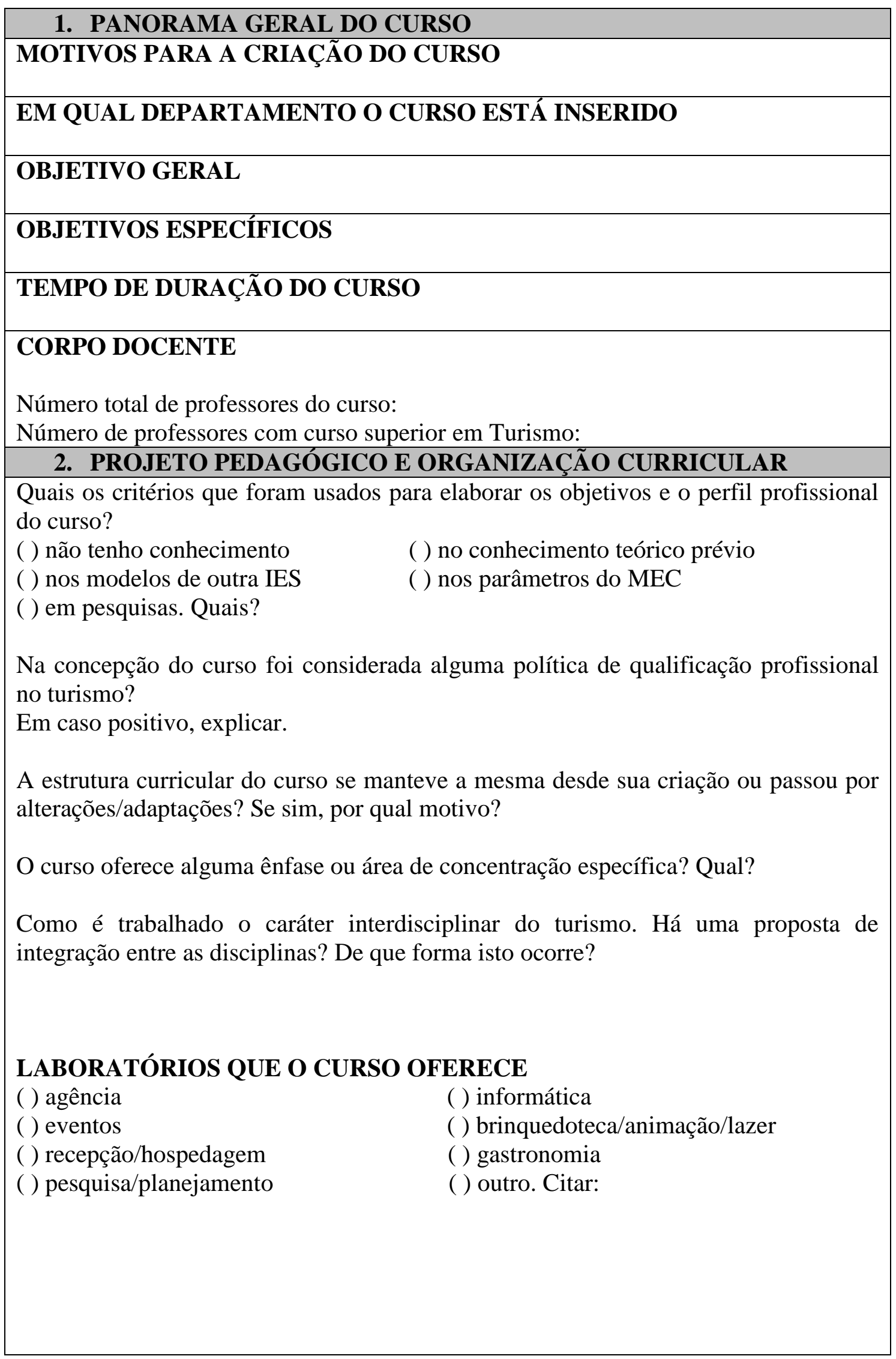


3. ESTÁGIO E ATIVIDADES COMPLEMENTARES

Atividades complementares que são oferecidas no curso:

Carga horária mínima de atividades complementares que devem ser realizadas pelo estudante:

Áreas possíveis para realização de estágio:

Carga horária mínima do estágio obrigatório:

Instrumentos de avaliação do estágio obrigatório:

( ) Relatórios feitos pelos estudantes

( ) Relatórios feitos pela empresa

( ) Acompanhamento direto de um professor / orientador

( ) Outro. Citar

4. PERFIL PROFISSIONAL DO EGRESSO

HABILIDADES E ATITUDES

Intelectuais

Pessoais e Interpessoais

Profissionais

\section{COMPETÊNCIAS}

\section{ÁREAS QUE O ALUNO ESTARÁ APTO A TRABALHAR}

( ) empresas privadas do trade (hotéis, agências, transportes, eventos, lazer, gastronomia)

( ) planejamento no setor público e privado

( ) gestão no setor público e privado

( ) meio ambiente

( ) consultoria

( ) educação

FORMAÇÃO VOLTADA PARA:
( ) o mercado de trabalho
( ) a academia (pesquisa e ensino)
( ) a sociedade
( ) outros. Citar:
( ) todos

\section{PERFIL GERAL}

\section{PARCERIAS COM EMPRESAS PÚBLICAS E/OU PRIVADAS}

O curso realizou alguma pesquisa em parceria com empresa pública ou privada voltada à qualificação profissional nos últimos 5 anos?

Formas de participação do curso em parcerias com instituições públicas e privadas:
( ) inventário turístico
( ) pesquisa
( ) estágio curricular
( ) planejamento
( ) projetos (sustentabilidade, cadeias produtivas, qualificação profissional, etc.)
( ) elaboração de roteiros e produtos ( ) outros. Citar:

QUESTIONÁRIO PREENCHIDO POR

Nome:

Em: / /2015.

E-mail:

Telefone: 


\section{APÊNDICE B \\ QUESTIONÁRIO PARA EGRESSOS DE CURSOS DE TURISMO}

Este apêndice apresenta o questionário aplicado junto aos turismólogos que atuam na atividade turística.

Prezado (a),

Estamos realizando uma pesquisa com o objetivo de investigar a relação entre as competências trabalhadas na formação acadêmica e as aptidões requisitadas pelo mundo do trabalho contemporâneo. Esta pesquisa faz parte da Dissertação de Mestrado intitulada Construção do Conhecimento do Turismo: competências necessárias para o exercício da profissão do Turismólogo. O Mestrado faz parte do Programa de Pós Graduação em Turismo do Centro de Excelência em Turismo da Universidade de Brasília.

Para tanto, agradeceríamos a especial gentileza de nos devolver o Questionário de Pesquisa (anexo). Reafirmando a relevância dessa pesquisa, consideramos a sua resposta de suma importância para o estudo científico da educação em Turismo. Certos de sua colaboração, aguardamos sua valiosa participação.

Atenciosamente, 


\section{PERFIL GERAL}

Principal motivo da escolha pelo curso de Turismo:

Instituição de ensino superior na qual concluiu a graduação:

Tempo para conclusão do curso e ano em que foi concluído:

Área de atuação, cargo e cidade onde atua:

\section{CURRÍCULO}

Considera que os conteúdos abordados tiveram equilíbrio entre teoria e prática? Explique.

Acredita que a proposta curricular do seu curso apresentava a característica interdisciplinar do turismo? Havia uma proposta de integração entre as disciplinas?

Em relação ao mercado de trabalho você considera que a proposta curricular foi relevante e auxiliou de fato para a prática profissional?

\section{ESTÁGIO E ATIVIDADES COMPLEMENTARES REALIZADAS DURANTE O CURSO}

\section{LABORATÓRIOS NOS QUAIS PARTICIPOU DURANTE O CURSO}

( ) agência

( ) eventos

( ) recepção/hospedagem

( ) pesquisa/planejamento
( ) informática / sistemas

( ) brinquedoteca/animação/lazer

( ) gastronomia

( ) outro. Citar:

\section{EXPECTATIVAS X REALIDADE DO MERCADO}

A proposta curricular atendeu suas expectativas iniciais em relação a um curso de turismo? Explique:

Você acredita que o currículo do seu curso atendeu as demandas do mercado? Justifique:

Durante a graduação, quais atividades e/ou disciplinas mais colaboraram para o desempenho do seu trabalho atual?

Você sentiu falta de realizar alguma atividade complementar que colaborasse para a atuação profissional? Se sim, qual atividade considera ter faltado durante o curso? 


\section{CENÁRIO PROFISSIONAL ATUAL E PERSPECTIVAS}

Quanto à atividade que você desempenha, considera que:

( ) não agrega grande valor

( ) pode ser realizada por um profissional de outra área

( ) tem grande significado para você

( ) não sabe bem qual é a sua contribuição

Quanto à sua remuneração, você considera que está compatível, inferior ou superior a outras áreas de formação? Porque?

Você acredita que as competências e habilidades demandadas pelo mercado estão de acordo com a remuneração oferecida?

Você considera que tem possibilidades de ascensão profissional e pretende continuar atuando na área? Justifique:

Comente sobre sua impressão pessoal acerca da formação acadêmica adquirida em relação à demanda atual do mercado do turismo e sobre suas perspectivas de um cenário futuro da profissão do turismólogo.

\section{QUESTIONÁRIO PREENCHIDO POR}

Nome:

Em: / /2015.

E-mail:

Telefone: 